\title{
CONDIÇÕES MICROBIOLÓGICAS E AVALIAÇÃO DA PASTEURIZAÇÃO EM AMOSTRAS DE LEITE COMERCIALIZADAS NO MUNICÍPIO DE PIRACICABA-SP
}

\author{
Ricardo Pinheiro de Souza Oliveira
}

Dissertação apresentada à Escola Superior de Agricultura "Luiz de Queiroz", Universidade de São Paulo, para obtenção do título de Mestre em Ciências, Área de Concentração: Ciência e Tecnologia de Alimentos.

P I R A C I C A B A

Estado de São Paulo - Brasil

Maio-2005 


\section{CONDIÇÕES MICROBIOLÓGICAS E AVALIAÇÃO DA PASTEURIZAÇÃO EM AMOSTRAS DE LEITE COMERCIALIZADAS NO MUNICÍPIO DE PIRACICABA-SP}

\section{Ricardo Pinheiro de Souza Oliveira}

Engenheiro Agrônomo

Orientador: Prof. Dr. CLÁUDIO ROSA GALLO

Dissertação apresentada à Escola Superior de Agricultura "Luiz de Queiroz", Universidade de São Paulo, para obtenção do título de Mestre em Ciências, Área de Concentração: Ciência e Tecnologia de Alimentos.

P I R A C I C A B A

Estado de São Paulo - Brasil

Maio-2005 
Dados Internacionais de Catalogação na Publicação (CIP) DIVISÃO DE BIBLIOTECA E DOCUMENTAÇÃO - ESALQ/USP

Oliveira, Ricardo Pinheiro de Souza

Condições microbiológicas e avaliação da pasteurização em amostras de leite comercializadas no município de Piracicaba / Ricardo Pinheiro de Souza Oliveira. - Piracicaba, 2005.

81 p. : il.

Dissertação (mestrado) - - Escola Superior de Agricultura Luiz de Queiroz, 2005. Bibliografia.

1. Análise de alimento 2. Bactéria 3. Contaminação de alimento 4. Higiene de alimento 5. Indústria de alimento 6. Leite - Qualidade 7. Microbiologia de alimento 8. Pasteurização I. Título

CDD 637.1277

"Permitida a cópia total ou parcial deste documento, desde que citada a fonte - $\mathrm{O}$ autor" 


\section{DEDICATÓRIA}

À minha família (Carlos, Zenilda e Dudu) pelo

incentivo

compreensão,

amor

e por serem a maior razão da minha felicidade e existência.

\section{DEDICO}

`A Priscilla de Barros Rossetto, pela

paciência,

inspiração,

carinho

e amor.

OFEREÇO

“Os pescadores sabem que o mar é perigoso e a tormenta, terrível. Mas este conhecimento não os impede de lançar-se ao mar" Van Gogh 


\section{AGRADECIMENTOS}

Ao Prof. Dr. Cláudio Rosa Gallo, pela oportunidade, ensinamentos, orientação, amizade e confiança na realização deste trabalho e pelo enorme exemplo profissional;

Ao Prof. Dr. Ernani Porto pelo apoio, incentivo e sugestões, além da grande amizade;

Às técnicas Cecília Nogueira, Denise Baptista e Rosalina Ocangne, pela ajuda na realização deste trabalho e pela confiança que sempre depositaram em mim;

Ao Laboratório de Microbiologia de Alimentos da ESALQ/USP pela contribuição com os materiais utilizados;

À Prof ${ }^{\mathrm{a}} \mathrm{Dr}^{\mathrm{a}}$ Marília Oetterer, pelo incentivo e confiança na minha capacidade em realizar o mestrado;

À $\operatorname{Prof}^{\mathrm{a}} \operatorname{Dr}^{\mathrm{a}}$ Gilma Lucazechi Sturion, pela grande contribuição nas correções do meu trabalho;

À $\operatorname{Dr}^{\mathrm{a}}$ Maria Fernanda (ITAL) pela grande ajuda e sugestões no trabalho;

Às bibliotecárias, Bia e Midiam pelo constante apoio e preocupação com o meu trabalho;

À Lia pela atenção e auxílio nas traduções;

Às secretárias Gislaine, Márcia e Regina pela amizade e atenção;

Aos amigos e companheiros do curso de Mestrado em Ciência e Tecnologia de Alimentos; 
Ao Eduardo Moita e família pela fiel amizade, respeito, carinho e incentivo;

À tia Célia e o "zio" Vittorio pelo carinho, incentivo e preocupação, apesar da distância;

À minha família paulistana e baiana pelo apoio, carinho e compreensão.

MUITO OBRIGADO! 


\section{SUMÁRIO}

\section{Página}

LISTA DE FIGURAS................................................................... ix

LISTA DE TABELAS ..................................................................

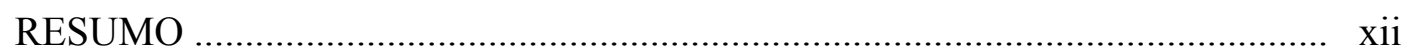

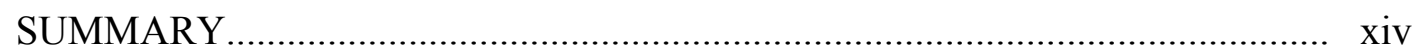

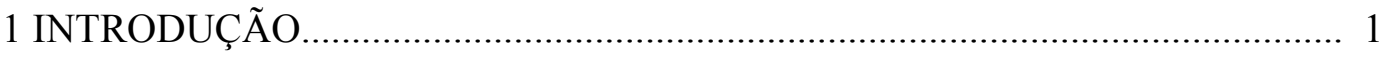

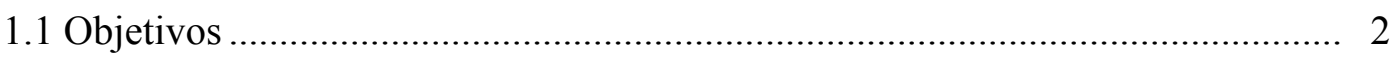

2 REVISÃO DE LITERATURA ................................................................. 3

2.1 A importância e a qualidade do leite.............................................................. 3

2.2 Etapas críticas para a contaminação do leite...................................................... 4

2.3 Contaminantes comuns do leite ..................................................................... 4

2.3.1 Bactérias aeróbias mesófilas ................................................................. 5

2.3.2 Bactérias aeróbias termófilas e psicrotróficas................................................. 6

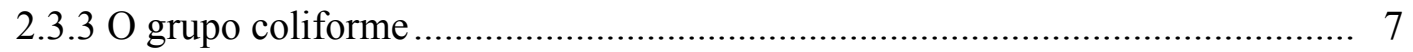

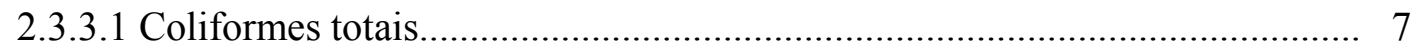

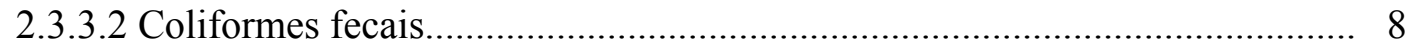

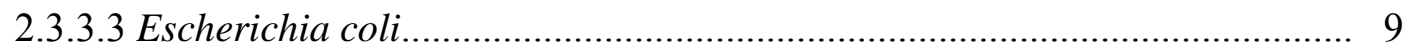

2.3.4 Staphylococcus coagulase positiva .............................................................. 9

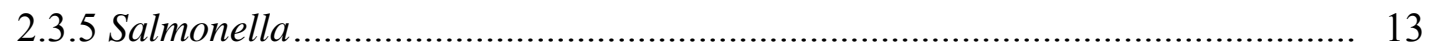

2.4 Inovação nos métodos de análise microbiológica............................................... 15

2.4.1 O sistema SimPlate ${ }^{\circledR}$ para coliformes totais e E. col .................................... 15

2.4.2 Kits rápidos para detecção de Salmonella...................................................... 16

2.4.2.1 O kit 1-2 Test da BioControl........................................ 16

2.4.2.2 O kit Salmonella Rapid Test da Oxoid................................ 17 
2.5 Tratamentos térmicos utilizados no leite..................................................... 17

2.5.1 Pasteurização e sua importância...................................................................... 17

2.5.2 Pontos críticos de controle no leite pasteurizado ........................................... 19

2.6 Classificação do leite ................................................................................ 21

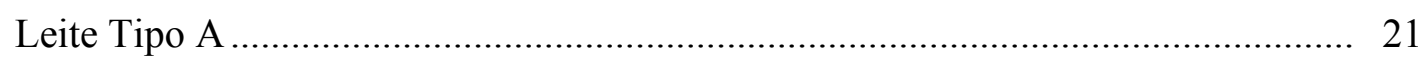

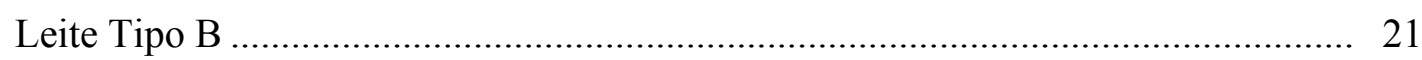

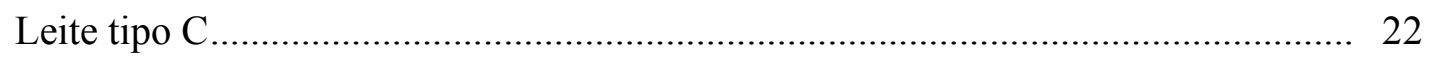

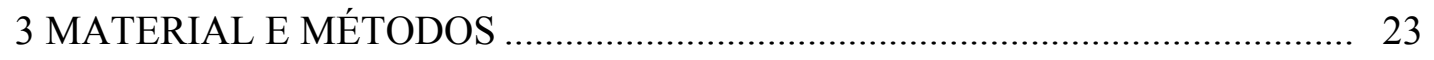

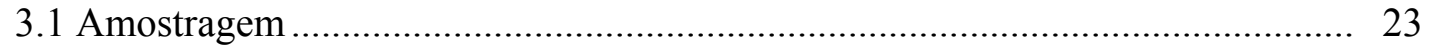

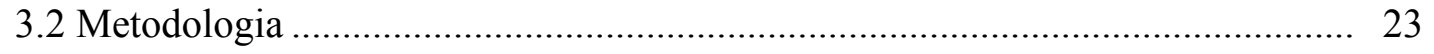

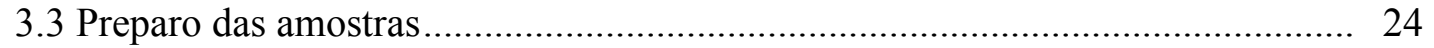

3.4 Contagem total de microrganismos aeróbios mesófilos, termófilos e

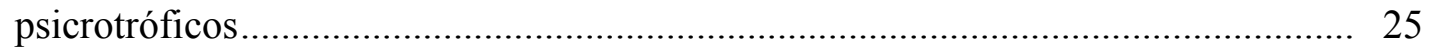

3.5 Número Mais Provável de coliformes totais e fecais....................................... 26

3.6 Numero Mais Provável de coliformes totais e E. coli pelo sistema SimPlate ${ }^{\circledR}$... 28

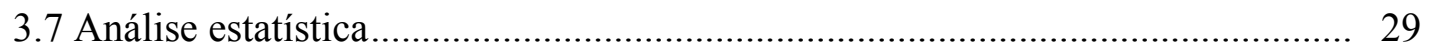

3.8 Contagem de Staphylococcus coagulase positiva ........................................... 29

3.9 Análise de Salmonella ....................................................................................... 32

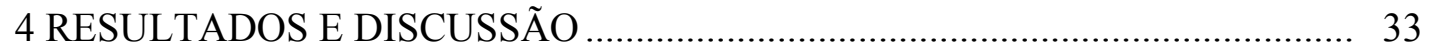

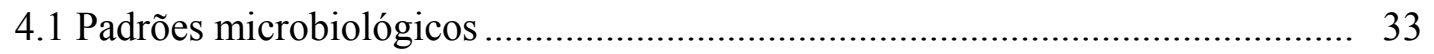

4.2 Contagem total de aeróbios mesófilos, termófilos e psicrotróficos ................... 34

4.2.1 Aeróbios mesófilos ............................................................................... 36

4.2.2 Aeróbios psicrotróficos ............................................................................ 39

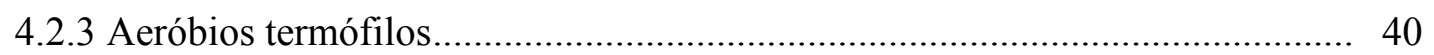

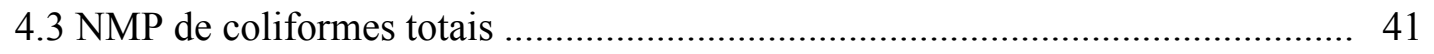

4.3.1 Análise de coliformes totais por tubos múltiplos........................................... 44

4.3.2 Análise de coliformes totais pelo método SimPlate ${ }^{\circledR}$.................................... 44

4.4 Número Mais Provável (NMP) de coliformes fecais .......................................... 46

4.4.1 Análise de coliformes fecais por tubos múltiplos ........................................... 48

4.4.2 Análise de E. coli pelo método SimPlate ${ }^{\circledR}$................................................ 49 
4.5 Comparação entre os métodos tubos múltiplos e SimPlate ${ }^{\circledR}$........................... 52

4.6 Contagem de Staphylococcus coagulase positiva ............................................ 54

4.7 Detecção de Salmonella .............................................................................. 57

4.8 Condições microbiológicas gerais das amostras de leite pasteurizado analisadas 58

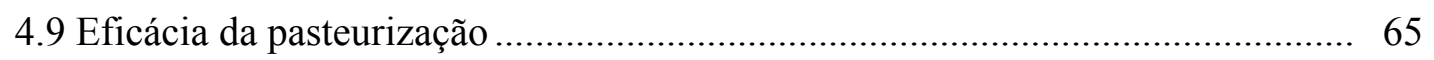

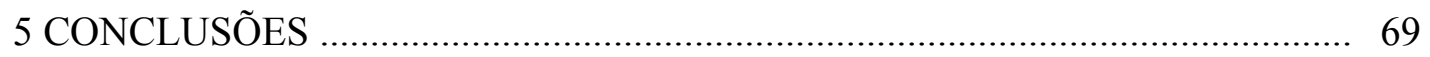

REFERÊNCIAS BIBLIOGRÁFICAS ............................................................. 71 


\section{LISTA DE FIGURAS}

Página

1 Fluxograma de beneficiamento do leite pasteurizado, evidenciando os pontos críticos de controle parcialmente eficaz (PCC2) e o totalmente eficaz (PCC1). Observam-se pontos importantes de contaminação (ロ), pontos de contaminação pouco importantes $(\mathbf{\Lambda})$, pontos de possível multiplicação de microrganismos $(+)$ e pontos de destruição térmica (x)

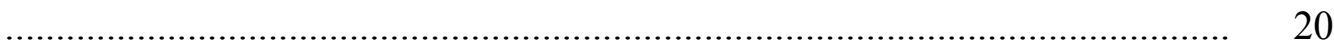

2 Pasteurização no laboratório em banho-maria a $62,8^{\circ} \mathrm{C} / 30^{\prime}$........................... 24

3 Preparo de diluições em série ..................................................................... 25

4 Procedimento para o plaqueamento e a contagem total de mesófilos, termófilos e psicrotróficos ………........................................................... 26

$5 \quad$ Procedimento para a estimativa do NMP de coliformes totais e fecais ........ 27

6 Teste confirmativo para coliformes totais em CVBLB a $35^{\circ} \mathrm{C}$ e confirmativo para coliformes fecais a $45^{\circ} \mathrm{C}$ em caldo EC ........................... 28

7 Placas de SimPlate ${ }^{\circledR}$ mostrando teste positivo para coliformes totais (cor púrpura) e E. coli (azul fluorescente)

8 Preparo para a contagem e o isolamento de Staphylococcus coagulase positiva

9 Colônias típicas de Staphylococcus coagulase positiva em meio BPA

10 Procedimento para a análise de Salmonella usando o kit 1-2 test da Biocontrol 
Médias das contagens de mesófilos, termófilos e psicrotróficos, antes e após

11 a pasteurização (past) em laboratório

12 Médias do NMP de coliformes totais encontradas para as amostras de leite pasteurizado tipos A, B, C e leite cru analisadas antes da pasteurização no laboratório e após a mesma

13 Médias do NMP de coliformes fecais $\left(45^{\circ} \mathrm{C}\right)$ obtidas pela técnica dos tubos múltiplos e de E. coli pelo método SimPlate ${ }^{\circledR}$, encontradas para as amostras de leite tipos A, B, C e leite cru analisadas antes da pasteurização no laboratório e após a mesma

14 Dispersão dos resultados das contagens (NMP) de coliformes totais em leite tipos A, B, C e cru obtidos pelos métodos NMP (tubos múltiplos) e SimPlate ${ }^{\circledR}$

15 Dispersão dos resultados das contagens (NMP) de coliformes fecais/E. coli em leite tipos A, B, C e cru obtidos pelos métodos NMP (tubos múltiplos) e SimPlate ${ }^{\circledR}$

16 Porcentagens de amostras de leite pasteurizado tipo A acima e dentro dos limites microbiológicos do DIPOA (Brasil, 2002)

17 Porcentagens de amostras de leite pasteurizado tipo B acima e dentro dos limites microbiológicos do DIPOA (Brasil, 2002)

18 Porcentagens de amostras de leite pasteurizado tipo $\mathrm{C}$ acima e dentro dos limites microbiológicos do DIPOA (Brasil, 2002)

19 Porcentagens de amostras de leite tipo pasteurizado acima e dentro dos limites microbiológicos da ANVISA (Brasil, 2001)

20 Médias das reduções logarítmicas conseguidas pela pasteurização realizada no laboratório para as amostras de leite pasteurizado tipos A, B, C e leite cru 


\section{LISTA DE TABELAS}

Página

1 Padrões microbiológicos para o leite tipo A, B e demais tipos........................... 34

2 Padrões microbiológicos para o leite tipo A, B e C............................................ 34

3 Padrões microbiológicos para leite pasteurizado (todos os tipos)....................... 34

4. Contagens totais de aeróbios mesófilos, termófilos e psicrotróficos pelo método convencional (PCA) em amostras de leite pasteurizado tipos A, B, C e leite cru, obtidas no comércio de Piracicaba, antes e após a pasteurização em laboratório.

$5 \quad$ Número Mais Provável (NMP) de coliformes totais pelo método convencional

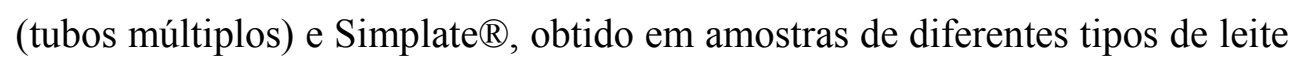
coletados no comércio de Piracicaba antes e após pasteurização em laboratório.

6 Número Mais Provável (NMP) de coliformes à $45^{\circ} \mathrm{C}$ pelo método convencional (tubos múltiplos) e E. coli pelo Simplate ${ }^{\circledR}$ encontrado em amostras de leite obtidas no comércio de Piracicaba antes e após pasteurização em laboratório.

7 Resumo das comparações estatísticas entre os métodos NMP (tubos múltiplos) e SimPlate ${ }^{\circledR}$ para contagem de coliformes totais e fecais/E. coli nas amostras de leite tipos A, B, C e cru.

8 Contagens de Staphylococcus coagulase positiva obtidas em amostras de leite adquiridas no comércio local de Piracicaba antes e após pasteurização em laboratório

9 Amostras de leite pasteurizado tipos A, B, C em desacordo com os padrões microbiológicos estabelecidos pelo DIPOA (Brasil, 2002).

10 Eficácia da pasteurização (log) realizada no laboratório, das amostras de leite tipos A, B, C e cru obtidas no comércio de Piracicaba. 


\title{
CONDIÇÕES MICROBIOLÓGICAS E AVALIAÇÃO DA PASTEURIZAÇÃO EM AMOSTRAS DE LEITE COMERCIALIZADAS NO MUNICÍPIO DE PIRACICABA-SP
}

\author{
Autor: RICARDO PINHEIRO DE SOUZA OLIVEIRA \\ Orientador: Prof. Dr. CLÁUDIO ROSA GALLO
}

\section{RESUMO}

O leite é um dos alimentos mais completos da natureza e sua importância é baseada em seu elevado valor nutritivo, como riqueza de proteínas, vitaminas, gordura, sais minerais e a alta digestibilidade. Esses fatores são relevantes para considerá-lo um excelente meio de cultura para a maioria dos microrganismos. A pasteurização é necessária e tem a finalidade de eliminar os microrganismos patogênicos, além de diminuir ao máximo o número de microrganismos em geral, mas alguns deles ainda podem sobreviver ao tratamento térmico aplicado. O objetivo do presente trabalho foi avaliar a condição microbiológica e a eficácia da pasteurização industrial do leite tipos $\mathrm{A}, \mathrm{B}, \mathrm{C}$ e as condições microbiológicas do leite cru, através da enumeração de bactérias aeróbias mesófilas, termófilas e psicrotróficas, Staphylococcus coagulase positiva, determinação do Número Mais Provável (NMP) de coliformes totais e fecais e pesquisa de Salmonella spp. em 30 amostras de leite comercializado no município de PiracicabaSP. Com base na legislação do DIPOA (Brasil, 2002) os resultados mostraram que $44,4 \%$ das amostras de leite tipo A apresentaram-se fora do padrão microbiológico para aeróbios mesófilos. Para coliformes totais e fecais, o mesmo leite apresentou $66,7 \%$ e 
$55,6 \%$ das amostras respectivamente, em desacordo com a legislação vigente. No leite tipo $\mathrm{B}$, nenhuma amostra esteve fora do padrão microbiológico em relação a aeróbios mesófilos. Já para coliformes totais e fecais, 33,3\% das amostras estiveram em desacordo com a legislação em vigor. $\mathrm{O}$ leite tipo $\mathrm{C}$ foi o que apresentou resultado mais satisfatório, pois ao contrário do que se esperava, nenhuma amostra esteve fora do padrão em relação às análises microbiológicas realizadas no presente trabalho. O leite cru analisado apresentou valores elevados para todas as análises microbiológicas realizadas. Não foram encontradas amostras contaminadas com Salmonella spp. em todas as amostras de leite analisadas. O maior valor encontrado para Staphylococcus coagulase positiva foi $1,1 \times 10^{2} \mathrm{UFC} / \mathrm{mL}$, portanto, longe da dose infectiva, mas esse fato não deixa de ser preocupante, já que o leite é um ótimo substrato para bactérias. Após a pasteurização $\left(62,8^{\circ} \mathrm{C} / 30^{\prime}\right)$ realizada no Laboratório de Microbiologia de Alimentos, do Departamento de Agroindústria, Alimentos e Nutrição, da ESALQ, todas as amostras novamente analisadas para os parâmetros microbiológicos citados, se mostraram em acordo com a legislação nacional vigente (Brasil, 2002). Os resultados encontrados na presente pesquisa podem ser indicativos de prováveis falhas do binômio tempo/temperatura durante a pasteurização industrial; matéria-prima excessivamente contaminada; higienização e sanificação deficientes das linhas de produção ou contaminação pós-pasteurização. 


\title{
MICROBIOLOGICAL CONDITIONS AND ASSESSMENT OF PASTEURIZATION IN MILK SAMPLES COMMERCIALIZED IN PIRACICABA-SP
}

\author{
Author: RICARDO PINHEIRO DE SOUZA OLIVEIRA \\ Adviser: Prof. Dr. CLÁUDIO ROSA GALLO
}

\section{SUMMARY}

Milk is one of the most valuable of all foods in nature and its importance is based on its high nutritive value. Milk is rich in proteins, vitamins, fat, mineral salts, and high digestibility. These factors are relevant for it to be considered an excellent culture medium for most microorganisms. Pasteurization is necessary and its main purpose is to eliminate pathogenic microorganisms, in addition to reducing to the maximum the number of microorganisms in general. However, some of them may still outlive the thermal treatment applied. The aim of this project was to evaluate the microbiological conditions and efficiency of the industrial pasteurization of type-A,-B and-C milk, and the microbiological conditions of raw milk, through the number of mesophillic, thermophilic and psychrotrophic aerobe bacteria, Staphylococcus positive coagulase, through the determination of the Most Probable Number (MPN) of total and fecal coliforms, and also through the research on Salmonella spp. in 30 samples of milk commercialized in Piracicaba-SP. Based on DIPOA legislation (Brazil, 2002), the results showed that $44.4 \%$ of the type-A milk samples did not meet the microbiological standard for mesophillic aerobe for total and fecal coliforms, $66.7 \%$ and $55.6 \%$ of the same milk samples, respectively, were not in accordance with the present legislation. For 
the type-B milk, no sample failed to meet the microbiological standard in relation to mesophillic aerobes. However, for total and fecal coliforms, 33.3\% of the samples were in disagreement with the present legislation. Type-C milk was the one presenting the best result. All samples were in accordance with the microbiological analysis performed in this work. The raw milk examined showed high values for all microbiological analyses. No infected samples with Salmonella spp. were found in the analyzed milk samples. The greatest value found for Staphylococcus positive coagulase was $1.1 \times 10^{2}$ $\mathrm{UFC} / \mathrm{mL}$, thus, far from the infective dose, although somewhat concearning since milk is considered na excellent environment for the infestation of bacteria. After the pasteurization $\left(62.8^{\circ} \mathrm{C} / 30^{\prime}\right)$ performed in the Food Microbiology Laboratory, of the Agroindustry, Foods and Nutrition Department, ESALQ/USP, all samples that analyzed again, based on the microbiological parameters mentioned above, met the national legislation in force (Brazil, 2002). The results found in the research may be an indication of probable failures regarding time/temperature during the industrial pasteurization; infected raw-material; defecient sanitation of product lines or post-pasteurization contamination. 


\section{INTRODUÇÃO}

O leite é um alimento que possui um perfeito balanço de nutrientes, fornecendo ao homem macro e micronutrientes indispensáveis ao crescimento, desenvolvimento e manutenção da saúde. Como fonte de proteínas, lipídeos, carboidratos, minerais e vitaminas, torna-se um dos alimentos mais vulneráveis a alterações físico-químicas e deterioração por microrganismos. Estes contaminantes podem causar modificações físico-químicas e organolépticas, que limitam a durabilidade do leite e seus derivados, além de problemas econômicos e de saúde pública (Freitas et al., 2002; Lopez \& Stamford, 1997; Souza \& Cerqueira, 1996).

O Brasil apresenta grande potencial no consumo e na produção de lácteos. Apresenta uma das maiores taxas de crescimento na produção e vem participando do mercado exterior de forma incipiente. Apresenta também área disponível e uma diversidade de sistemas de produção viáveis. Além disso, devem-se considerar as boas relações diplomáticas com os principais mercados importadores, como os do Oriente Médio e Norte da África, possuindo uma cultura exportadora de agronegócio mundial (FNP, 2004).

No Brasil, apesar do desenvolvimento tecnológico atingido em certos laticínios, persistem ainda em nível de produção de leite, graves problemas que depreciam a matéria-prima, que impedem o seu beneficiamento para consumo "in natura" ou tornam o produto beneficiado impróprio para o consumo humano, mesmo nas regiões onde a pecuária leiteira é tradicional (Fonseca, 1998; Freitas et al., 2002; Nader Filho et al., 1997). 
A higiene e o controle do leite, assim como dos produtos lácteos, têm como objetivo básico assegurar a inocuidade. A presença de taxas suficientemente altas de certos microrganismos e suas toxinas constituem as causas mais freqüentes de problemas sanitários, além de grandes perdas econômicas.

Os procedimentos higiênicos dispensados durante a obtenção e a manutenção do leite até sua entrada no estabelecimento de beneficiamento determinaram o tipo e a quantidade desses contaminantes. A saúde do rebanho leiteiro, as boas práticas durante a ordenha, a conservação do leite em baixa temperatura até o momento do processamento são fundamentais para evitar o desenvolvimento dos microrganismos responsáveis pela sua deterioração. Estes cuidados são essenciais para fabricação de bons produtos derivados, já que o leite é utilizado como matéria-prima (Ponsano et al., 1999).

Atualmente, o leite utilizado pela indústria deve ser de altíssima qualidade para se obter o máximo de rendimento na produção de produtos lácteos e também aumentar o tempo de vida útil; portanto, o estabelecimento de normas e padrões oficiais tem levado as indústrias a implantarem sistemas que garantam a qualidade de seus produtos.

\subsection{Objetivos}

O presente trabalho teve como objetivos:

- Avaliar as condições microbiológicas e de pasteurização em amostras de leite comercializadas no município de Piracicaba-SP;

- Avaliar o método SimPlate ${ }^{\circledR}$ em comparação com o método convencional (NMP - tubos múltiplos) para enumeração de bactérias do grupo coliforme em amostras de leite pasteurizado tipos A, B, C e leite cru;

- Avaliar a eficácia da pasteurização realizada no Laboratório de Microbiologia de Alimentos do Departamento de Agroindústria, Alimentos e Nutrição da ESALQ/USP. 


\section{REVISÃO DE LITERATURA}

\subsection{A importância e a qualidade do leite}

Tendo em vista a importância do leite sob os aspectos nutricionais, econômicos, sociais e de saúde pública, a qualidade desse produto tem merecido a atenção de inúmeros pesquisadores em todo o mundo. A higiene leiteira, ou seja, a produção de leite limpo e sadio, tem por objetivo oferecer um produto com valor nutricional, não comprometendo a saúde humana. É inexistente uma barreira entre higiene e profilaxia, pois a profilaxia é a ciência que trata dos meios de impedir a eclosão e a transmissão de doenças; a higiene é a primeira medida a ser adotada ao se fazer profilaxia (Garcia et al., 2000).

A contaminação do leite inicia-se na fazenda, durante ou após a ordenha, devido à ineficiência de higienização de utensílios e do homem, além de doenças do rebanho. Não se deve esquecer que as dificuldades de transporte, falhas no processo de beneficiamento e a estocagem podem interferir diretamente sobre a qualidade do leite. Dessa forma, para que seja mantida a qualidade do leite é preciso produzí-lo, pasteurizálo e comercializá-lo de maneira correta, de acordo com os parâmetros técnicos estabelecidos pela legislação. Nos últimos anos, um número crescente de laticínios e cooperativas vem remunerando o produtor de leite de acordo com a qualidade da matéria-prima fornecida para a indústria (Franco \& Landgraf, 1996; Garcia et al., 2000).

Apesar dos padrões impostos pela legislação, verifica-se uma situação preocupante, pois não há uma realização diária das análises físico-químicas, enzimáticas e microbiológicas em algumas mini e micro-usinas de beneficiamento no Estado de São Paulo, o que impossibilita a avaliação da qualidade do leite destinado para o consumo 
humano. Esse fator inviabiliza a rápida identificação e imediata correção das prováveis falhas no processo de beneficiamento. Até mesmo nas grandes usinas de beneficiamento, subordinadas à fiscalização diária e permanente do Serviço de Inspeção Federal, podem surgir problemas relativos à qualidade do leite pasteurizado (Nader Filho et al., 1997).

Vale notar que o comércio informal de leite é uma grande ameaça à saúde pública. Segundo a Organização Mundial de Saúde (OMS), dezesseis doenças bacterianas e sete viróticas são veiculadas pelo produto comercializado nessas condições, dentre elas, a tuberculose e gastroenterites, conseqüentes da baixa qualidade do leite (Agnese, 2002).

\subsection{Etapas críticas para a contaminação do leite}

As etapas de ordenha e armazenamento do leite até que seja entregue na indústria são críticas para sua contaminação, que é extremamente variável. A grandeza e a diversidade da população contaminante variam consideravelmente e estão intimamente associadas à origem do leite (Harvey \& Hill, 1989; Pelczar et al., 1996).

A ordenha, preferencialmente mecânica, deve ocorrer dentro dos mais criteriosos padrões sanitários. Mesmo em condições ótimas, o leite apresentará uma carga microbiana que deve ser mantida constante, evitando a multiplicação da mesma no leite (Ajzental, 1994).

Segundo Bramley \& Mckinnon (1990), os níveis de contaminação no ar e o volume de ar que passa no interior dos equipamentos incorporam ao leite uma quantidade muito baixa de microrganismos, em torno de $<5 \mathrm{UFC} / \mathrm{mL}$ de leite produzido e $<1$ esporo de Bacillus.

\subsection{Contaminantes comuns do leite}

Quando o leite é proveniente de animais sadios e obtido em condições higiênicas adequadas, o número de microrganismos é baixo, sendo predominantes Micrococcus, Streptococcus e Corynebacterium, além de lactobacilos saprófitas do úbere e canais galactóforos (Jay, 1996). 
Normalmente, a microbiota contaminante do leite é composta por bactérias, enquanto as leveduras e fungos são mais raros de serem encontrados (Lima, 1998). Dentre os contaminantes estão as bactérias láticas, coliformes, Micrococcus, Staphylococcus, Enterococcus, Bacillus, esporos de Clostridium e bastonetes Gramnegativos (Jay, 1996). Em condições adequadas de manipulação e armazenamento, predomina a flora Gram-positiva (Jay, 1998).

\subsubsection{Bactérias aeróbias mesófilas}

Os mesófilos incluem um grupo de microrganismos capazes de se multiplicarem numa faixa de temperatura entre 20 e $45^{\circ} \mathrm{C}$, tendo uma temperatura ótima de crescimento a $32^{\circ} \mathrm{C}$ e, portanto, encontrando nas temperaturas ambientes de países de clima tropical, condições ótimas para o seu metabolismo (Franco \& Landgraf, 1996).

Esse grupo é muito importante, por incluir a maioria dos contaminantes do leite, tanto deterioradores como patógenos. É considerado um bom indicador de qualidade microbiológica, sendo a contagem microbiana em placa realizada para se avaliar as condições higiênicas na qual o produto foi processado (Jay, 1996; Teixeira et al., 2000).

Contagens microbianas elevadas de mesófilos no leite pasteurizado podem indicar uma matéria-prima excessivamente contaminada ou permanência em temperatura de abuso, manipulação inadequada, equipamentos da planta de processamento não adequadamente sanitizados e pasteurização deficiente (Rogick, 1987; Vieira, 1976).

O método de contagem de microrganismos em placas pode ser utilizado para contagem de grandes grupos microbianos, como aeróbios mesófilos, psicrotróficos, termófilos, variando-se apenas a temperatura e o tempo de incubação.

O meio de cultura mais utilizado na metodologia convencional é o Agar Padrão para Contagem (PCA) (Hajdenwurcel, 1998). Esta contagem detecta o número de bactérias aeróbias ou facultativas e mesófilas $\left(35-37^{\circ} \mathrm{C}\right)$, presentes em forma vegetativa ou também esporulada (Hayes, 1995). 


\subsubsection{Bactérias aeróbias termófilas e psicrotróficas}

As bactérias termófilas são definidas como aquelas cuja temperatura ótima de crescimento situa-se entre 55 e $65^{\circ} \mathrm{C}$, como máximo, para algumas espécies, podendo atingir entre 75 e $90^{\circ} \mathrm{C}$ e o mínimo em torno de $35^{\circ} \mathrm{C}$. O leite cru, normalmente, contém poucas bactérias termófilas, embora com capacidade de se desenvolverem no leite quando mantido a temperaturas elevadas, podendo atingir grande número destes microrganismos no produto. Essas bactérias constituem problema no leite pasteurizado quando algumas porções são mantidas, por algum tempo, entre 50 e $70^{\circ} \mathrm{C}$ (Silveira, 1998).

O termo psicrotrófico tem confundido os microbiologistas desde o começo do século XX. Outros termos são usados, tais como: psicrófilos, psicrófilos facultativos, tolerantes ao frio ou psicrotolerantes (Gounot, 1986). Segundo Collins (1981), de acordo com as normas da International Dairy Federation, os psicrotróficos foram definidos como sendo os microrganismos que podem crescer à $7^{\circ} \mathrm{C}$ ou menos, independente da temperatura ótima de crescimento. Esse grupo é extremamente importante em produtos que são conservados ou armazenados em condições de refrigeração por períodos longos (1 a 4 semanas). O problema torna-se ainda mais sério quando se considera que o uso intensivo da refrigeração, desde a fazenda até a residência do consumidor, pode provocar uma gradativa seleção para esse grupo. Tem-se observado que um grande número de espécies, consideradas restritamente mesófilas, já estão sendo incluídas também entre os psicrotróficos (Santana, 2001; Silveira, 1998).

A refrigeração do leite após a ordenha e sua conservação em baixas temperaturas $\left(4^{\circ} \mathrm{C}\right)$, condiciona o desenvolvimento da microbiota e pode impedir o crescimento de microrganismos mesófilos. Esse tratamento térmico logo após a obtenção do leite, tem ampliado consideravelmente o período de tempo em que se armazena o leite até a sua pasteurização, ocasionando uma redução no número de bactérias mesófilas, embora possa se observar um crescimento de microrganismos psicrotróficos, que posteriormente podem causar perdas econômicas (Santana, 2001; Wendpap \& Rosa, 1997). 
Os microrganismos psicrotróficos encontrados no leite são em sua maioria Gram-negativos, provenientes do meio ambiente e equipamentos de ordenha. Os Grampositivos também estão presentes, porém em menor quantidade. Os psicrotróficos Grampositivos mais freqüentes no leite cru resfriado pertencem aos gêneros Micrococcus, Bacillus e Arthrobacter. Mesmo quando presentes em pequenas quantidades no leite, podem causar alterações decorrentes de multiplicação com degradação de seus componentes. Apesar de serem facilmente destruídos pela pasteurização, suas enzimas proteolíticas e lipolíticas são termorresistentes e promovem alterações físicas e organolépticas no leite e seus derivados mesmo após o tratamento térmico (Andrade et al., 1998; Santana, 2001; Santos, 1999).

O microrganismo psicrotrófico encontrado com maior freqüência em leite refrigerado cru e pasteurizado é do gênero Pseudomonas, por apresentar melhor capacidade de crescimento em ambiente refrigerado do que outras bactérias Gramnegativas (Santos, 1999; Sorhaung \& Stepaniak, 1997).

Em um estudo de freqüência de psicrotróficos em leite e ambiente de ordenha observou-se que em leite cru, $81,62 \%$ dos mesófilos são microrganismos psicrotróficos, dos quais $63,35 \%$ são proteolíticos e $64,14 \%$ são lipolíticos. Em outra pesquisa, foi observado que alguns gêneros de coliformes são considerados psicrotróficos, representando $10-20 \%$ da microbiota isolada de leite cru estocado entre $5-7^{\circ} \mathrm{C}$ (Bramley \& Mckinnon,1990; Muir,1996; Santos ,1999).

\subsubsection{O grupo coliforme}

Os coliformes estão muito difundidos e podem ser detectados em vários tipos de alimentos, mas não indicam, necessariamente, uma contaminação de origem fecal, no sentido de envolver contato direto ou indireto com fezes. A presença destes microrganismos em leites crus é freqüentemente atribuída às práticas precárias de higiene durante a ordenha e nas etapas subseqüentes (Moreno et al., 1999).

De acordo com Oliveira \& Caruso (1996), testes para organismos coliformes em leite têm a finalidade de avaliar as condições sanitárias de produção, determinar a 
presença de infecções do úbere causada por certas espécies deste grupo e também avaliar a eficiência da pasteurização, já que o grupo de microrganismos coliformes totais e fecais é considerado indicador das condições higiênicas da produção e beneficiamento do leite pasteurizado.

A utilização do grupo coliforme como indicador das condições higiênicosanitárias em alimentos, é prática estabelecida há muitos anos. Dos agentes bacterianos, os coliformes são internacionalmente considerados microrganismos indicadores da segurança microbiológica de alimentos (Bonassi, 1984; Frazier \& Westhoff, 1993; Nascimento et al., 1991; Rogick, 1987; Vanderzant \& Splittstoesser, 1992).

\subsubsection{Coliformes totais}

O grupo dos coliformes totais compreende principalmente os gêneros Escherichia, Citrobacter, Enterobacter e Klebsiella. Encontram-se bactérias originárias do trato gastrintestinal de humanos e outros animais de sangue quente, como também diversos gêneros e espécies de bactérias não entéricas. Portanto, a enumeração em água e alimentos é menos representativa, como indicação de contaminação fecal do que a enumeração de coliformes fecais ou E. coli (Silva et al., 1997).

O grupo de microrganismos coliformes totais é restrito ao trato gastrintestinal de humanos e animais homeotérmicos. Este grupo inclui bactérias aeróbias e anaeróbias facultativas, Gram-negativas, não esporogênicas, com capacidade de fermentar a lactose com produção de gás num período de 48 horas a $35^{\circ} \mathrm{C}$ (Siqueira, 1995; Vanderzant \& Splittstoesser, 1992).

\subsubsection{Coliformes fecais}

Os coliformes fecais também são coliformes totais que continuam fermentando a lactose, com produção de gás quando incubados a $44-45,5^{\circ} \mathrm{C}$ (Vanderzant \& Splittstoesser, 1992). Neste grupo, são incluídas além da E. coli, espécies de Enterobacter e Klebsiella, embora algumas cepas dos gêneros Enterobacter e Klebsiella, 
podem não ter origem entérica (Hajdenwurcel, 1998).

\subsubsection{Escherichia coli}

Dentro do grupo dos coliformes fecais, a E. coli é a melhor indicadora de contaminação fecal direta ou indireta conhecida até o momento. Nas fezes humanas e de animais, cerca de 95\% dos coliformes existentes são Escherichia coli (Hajdenwurcel, 1998; Silva et al., 2000).

A presença dessa bactéria tem um significado importante, uma vez que existem linhagens patogênicas, com base nos fatores de virulência, manifestações clínicas e epidemiológicas para o homem e animais (Franco \& Landgraf, 1996).

\subsubsection{Staphylococcus coagulase positiva}

Os estafilococos apresentam-se na forma de cocos Gram-positivos, isolados ou agrupados em cachos, pares e tétrades. São anaeróbios facultativos, com maior crescimento sob condições aeróbias, não esporogênicos, produtores usuais de catalase e imóveis. São bactérias mesófilas apresentando temperatura de crescimento na faixa de $7^{\circ} \mathrm{C}$ a $47,8^{\circ} \mathrm{C}$, mas as enterotoxinas são produzidas entre 10 e $46^{\circ} \mathrm{C}$, com ótimo entre $40^{\circ} \mathrm{C}$ e $45^{\circ} \mathrm{C}$. As bactérias deste gênero são tolerantes a concentrações de 10 a $20 \%$ de $\mathrm{NaCl}$ e a nitratos. Crescem em valores de atividade de água inferiores aos considerados mínimos para as bactérias não-halófilas. O valor mínimo de atividade de água (Aa) considerado é de 0,86 , no entanto, em condições ideais, o desenvolvimento é possível em Aa de 0,83. Esse microrganismo cresce na faixa de $\mathrm{pH}$ entre 4 e 9,8, com ótimo entre 6 e 7 (Franco e Ladgraf, 1996; Vanderzant \& Splittstoesser, 1992).

Segundo Pereira et al. (2000), os estafilococos foram inicialmente observados por Kock, em 1878, a partir de material purulento; cultivado em meios líquidos por Pasteur, em 1880, e, a primeira publicação que versou sobre estes microrganismos, em forma de cocos, e sua constância em abscessos agudos e crônicos, tiveram lugar na Escócia, nos idos de 1881. Foi também como decorrência destes estudos que passaram a 
receber a denominação de Staphylococcus uma vez que, quando observados microscopicamente, apresentavam-se sob forma de grãos arranjados ou dispostos como cachos de uvas.

Atualmente o gênero Staphylococcus é composto por cerca de 27 espécies, sendo que algumas são freqüentemente associadas a uma ampla variedade de infecções de caráter oportunista, em seres humanos e animais. Entre elas se destacam, em patologia humana, as espécies: Staphylococcus aureus, Staphylococcus epidermidis, Staphylococcus saprophyticus e Staphylococcus haemolyticus. Tradicionalmente, os estafilococos são divididos em duas categorias: coagulase positivos e coagulase negativos. Essa divisão é baseada na capacidade de coagular o plasma sanguíneo, que é uma propriedade considerada, há muito tempo, como importante marcador de patogenicidade dos estafilococos. Entre os coagulase positivos, Staphylococcus aureus representa a espécie geralmente envolvida em infecções humanas (Trabulsi et al., 1999).

Staphylococcus aureus é o agente mais comum de infecções patogênicas, além de causar vários tipos de intoxicações, seja na vigência de um processo infeccioso ou não. Este microrganismo pode ser encontrado em várias partes do corpo, como fossas nasais, garganta, intestinos e pele. $\mathrm{O}$ número de portadores nasais do germe varia de $30 \%$ a $50 \%$, sendo mais elevado entre as pessoas que trabalham em hospitais (Trabulsi et al., 1999).

Staphylococcus aureus é o principal agente responsável pela intoxicação estafilocócica, que ocorre devido à ingestão de alimentos que apresentam toxina préformada. Essas toxinas são chamadas enterotoxinas, sendo conhecidas cinco imunologicamente distintas (A, B, C, D e E) (Franco \& Landgraf, 1996).

De acordo com Bergdoll (1989), citado por Pereira et al. (1999), as características físico-químicas das enterotoxinas estafilocócicas apresentam similaridades entre si, que podem assim ser resumidas: constituem proteínas simples de peso molecular situado entre 26.000 a $29.000 \mathrm{D}$ e estruturadas em uma única cadeia polipeptídica rica em lisina, tirosina e ácidos aspártico e glutâmico. No estado ativo, as enterotoxinas resistem à ação de enzimas proteolíticas como pepsina, tripsina, quimiotripsina, papaína e renina. 
As enterotoxinas estafilocócicas apresentam também a propriedade de termorresistência, o que constitui ponto crucial em controle de qualidade de alimentos, uma vez que a enterotoxina pode persistir no produto final, após o processamento térmico (Pereira et al., 1999).

O quadro clínico observado na intoxicação estafilocócica tem suas características estabelecidas no vômito e diarréia. Náusea, calafrios, dores abdominais e prostração ocorrem usualmente e o estado febril é de rara ocorrência. Os sintomas clínicos se manifestam após um curto período de incubação (em média 4 horas), apresentando durabilidade fugaz, com caráter geralmente não fatal, retratada por uma fase aguda de início abrupto, mas auto-limitada e com restabelecimento do doente observado em torno de 24 a 72 horas (Bergdoll, 1990a, citado por Pereira et al., 1999).

A dose tóxica mínima, em experimentos conduzidos com voluntários humanos, foi relatada como sendo $0,05 \mu \mathrm{g} / \mathrm{Kg}(3,5 \mu \mathrm{g} / \mathrm{homem}$ de $70 \mathrm{Kg})$, dose esta suficiente para provocar vômito e diarréia (Bergdoll, 1990a, citado por Pereira et al., 1999).

As células de Staphylococcus aureus apresentam alguns componentes de superfície, assim como produzem várias substâncias extracelulares, que contribuem para sua virulência, entre os quais a cápsula, peptidioglicano da parede celular, ácidos teicóicos, proteína A, adesinas, hemolisinas e leucocidinas (Trabulsi et al., 1999).

Segundo Nervino (1997) citado por Zoli et al. (2002), vários alimentos já foram envolvidos em surtos de intoxicação estafilocócica, entre eles carnes cozidas, leite, cremes, tortas recheadas com creme, saladas de batata, atum, frango e presunto. A falha na manipulação associada à conservação inadequada dos alimentos nos estabelecimentos comerciais e nos domicílios foi a grande responsável pelos surtos. Deve-se também levar em conta o cozimento ou descongelamento inadequado, aproveitamento de sobras alimentares e utilização de equipamentos contaminados. Alimentos submetidos a tratamento térmico após um período de manutenção em condições que permitam o crescimento podem não apresentar células viáveis de $S$. aureus, destruídas pelo calor, e mesmo assim conter toxinas estafilocócicas, que são resistentes ao calor (Silva et al., 1997). 
A contagem de S. aureus em alimentos é feita com a finalidade de relacionar este microrganismo à saúde pública, para confirmar o envolvimento em surtos de intoxicação alimentar, e para controlar a qualidade higiênico-sanitária dos processos de produção de alimentos. Neste último caso, S. aureus serve como indicador de contaminação pós-processo ou das condições de sanificação das superfícies destinadas ao contato com alimentos (Silva et al., 1997).

As principais características utilizadas no isolamento de $S$. aureus são as características seletivas, como habilidade de crescer na presença de $10 \%$ de $\mathrm{NaCl}, 0,01$ a $0,05 \%$ de telurito de potássio, 0,2 a $0,5 \%$ de cloreto de lítio, 0,12 a $1,26 \%$ de glicina e 40 $\mathrm{mg} / \mathrm{L}$ de polimixina, entre outras, e as características diferenciais, como a habilidade de reduzir o telurito de potássio, produzindo colônias pretas, a habilidade para hidrolisar a gema de ovo, por ação de lipases e/ou lecitinases, produzindo halos claros em redor das colônias, a capacidade de utilizar o manitol e de crescer a $42-43^{\circ} \mathrm{C}$ em condições seletivas, a atividade de coagulase e de termonuclease, entre outras (Trabulsi, et al., 1999; Vanderzant \& Splittstoesser, 1992).

Há vários meios disponíveis para a contagem direta em placas, combinando uma ou mais características seletivas/diferenciais, como o Agar Manitol Sal, Agar Vogel-Johnson, Agar Azida Gema de Ovo, Agar Fenolftaleína Fosfato de Polimixina, entre outros (Silva et. al, 1997). Estes meios não devem ser utilizados para alimentos onde seria possível a presença de células injuriadas, como alimentos desidratados ou congelados, pois são considerados restritivos para a reparação de injúria. O Agar BairdParker (BP) também é um meio muito utilizado para o isolamento de S. aureus. Combina telurito de potássio $(0,01 \%)$, glicina $(1,2 \%)$ e cloreto de lítio $(0,5 \%)$, como agentes seletivos, e a redução do telurito e a hidrólise da gema de ovo, como características diferenciais. O meio contém ainda $1 \%$ de piruvato de sódio, agente eficiente na reparação de células injuriadas, tanto quanto da catalase, evitando o acúmulo de peróxido de hidrogênio (tóxico para as células) produzido em condições aeróbias, durante o crescimento e reparação (Vanderzant \& Splittstoesser, 1992).

O Ágar BP pode ser utilizado para o plaqueamento direto de alimentos processados ou "in natura", tanto na enumeração com finalidades indicativas como na 
enumeração com finalidades de saúde pública. Entretanto, o Agar BP não é capaz de suprimir completamente o crescimento de competidores de S. aureus, particularmente outras espécies não patogênicas do gênero Staphylococcus que produzem colônias semelhantes, havendo necessidade de submeter à colônia típica, testes adicionais para confirmação definitiva, como os testes de coagulase, termonuclease e catalase (Siqueira, 1995).

As colônias de Staphylococcus aureus, quando cultivadas no meio Agar Baird-Parker, são negras, lustrosas, convexas. Possuem de 1 a $5 \mathrm{~mm}$ de diâmetro, rodeados por halo de 2 a $5 \mathrm{~mm}$ de largura. A formação de colônias negras circundadas por um halo é devido a redução do telurito a telureto, e a lipólise e proteólise da gema, respectivamente (Franco \& Landgraf, 1996; Siqueira, 1995).

Através da prova da coagulase verifica-se a capacidade de certos microrganismos de coagularem o plasma, devido à produção de coagulase. S. aureus produz grandes coágulos, podendo o plasma ser inteiramente coagulado. Na prova da catalase verifica-se a presença ou ausência da enzima catalase no microrganismo. $S$. aureus é catalase positivo (Siqueira, 1995).

\subsubsection{Salmonella}

O gênero Salmonella, descrito por Lignières em 1900, em homenagem ao bacteriologista americano D.E. Salmon que, juntamente com Theobald Smith em 1894 isolaram a Salmonella choleraesuis, pertence à família Enterobacteriaceae (Le Minor, 1984).

As salmonelas têm a forma de bastonetes curtos, medindo de 0,7 - 1,5 x 2,0 5,0 micra. São bactérias Gram-negativas; não esporuladas; móveis por meio de flagelos peritríquios (exceto S. gallinarum e S. pullorum); anaeróbias facultativas, mas que podem crescer em meio comum na presença de oxigênio livre; produzem catalase; utilizam o citrato como fonte de carbono (exceto $S$. typhi e $S$. paratyphi A); reduzem o nitrato a nitrito; produzem ácido e gás a partir da glicose; geralmente produzem sulfeto de hidrogênio em Agar Tríplice Açúcar-Ferro; fermentam o dulcitol, porém não 
fermentam a sacarose, a salicina, o inositol, a rafinose, a amidalina e a lactose (Le Minor, 1984; Oliveira, 1984; Pelczar et al., 1996).

As salmonelas são organismos mesófilos, com ótimo de crescimento no intervalo de 35 a $37^{\circ} \mathrm{C}$, evidenciando certo crescimento na faixa entre 5 e $47^{\circ} \mathrm{C}$, embora a velocidade do mesmo seja sensivelmente reduzida abaixo de $10^{\circ} \mathrm{C}$ (D'Aoust, 1989; Doyle \& Cliver, 1990; Roitman et al., 1988).

Segundo Frazier \& Westhoff (1993), a Aa mínima para o crescimento da bactéria varia com o tipo de alimento, mas em geral, é da ordem de 0,93 a 0,95. Outro parâmetro de fundamental importância a se considerar é o $\mathrm{pH}$. Geralmente, as salmonelas crescem no intervalo de 4,5 a 9,0, com ótimo na faixa de 6,5 a 7,5. O pH mínimo para o desenvolvimento varia com o sorotipo, temperatura de incubação, tipo de ácido, composição do substrato e tensão de oxigênio, mas, de modo geral, em valores de pH abaixo de 4,0 e acima de 9,0, as salmonelas são lentamente destruídas (D’Aoust, 1989; Doyle \& Cliver, 1990; Roitman et al., 1988).

A busca de uma metodologia adequada e eficiente para detectar Salmonella em alimentos tem sido constante para todos os profissionais que trabalham na pesquisa desta bactéria. Apesar de nos últimos anos muitos métodos com tecnologias avançadas terem sido desenvolvidos para diagnosticar Salmonella em alimentos, o método cultural clássico, apesar de sua morosidade e labor, continua sendo amplamente utilizado em laboratórios de monitoramento de Salmonella nas indústrias de alimentos e sua eficiência representa confiabilidade nos resultados obtidos e a segurança no controle desta bactéria (Giombelli, 2000).

O método tradicional para detecção de Salmonella em alimentos pode garantir o isolamento desta bactéria mesmo em situações desfavoráveis, como por exemplo, em alimentos com microbiota competidora. Ainda o isolamento e identificação de Salmonella são um problema para indústria de alimentos, pois demora um longo tempo para obtenção dos resultados, já que são necessários dois dias para as etapas de préenriquecimento e enriquecimento seletivo, além de três dias para as etapas de isolamento em ágar seletivo, identificação bioquímica e confirmação com testes sorológicos (Brasil, 1992; FDA, 1998; Giombelli \& Silva, 2001). 


\subsection{Inovação nos métodos de análise microbiológica}

A análise de leite e produtos lácteos, para se verificar quais e quantos microrganismos estão presentes, é fundamental para que se conheça as condições de higiene do alimento, e, conseqüentemente, os riscos que podem oferecer à saúde do consumidor.

A análise microbiológica de leite e produtos lácteos era realizada empregandose metodologias desenvolvidas no início do século. O significativo desenvolvimento tecnológico no setor alimentício, a implementação cada vez mais freqüente dos conceitos de APPCC (Análise de Perigos e Pontos Críticos de Controle) e de Boas Práticas de Fabricação (BPF), além da ampliação dos conhecimentos sobre os microrganismos importantes em alimentos, estão indicando que os métodos convencionais necessitam ser substituídos por métodos alternativos mais modernos, mais adequados à constante busca pelo aumento da produtividade e da eficiência. Entre os vários métodos alternativos atualmente disponíveis, merecem destaque os sistemas denominados "prontos para uso", que agilizam as análises microbiológicas, tornando-as mais rápidas, precisas e com menor custo (Franco, 1998; Teixeira et al., 2000).

\subsubsection{O sistema SimPlate ${ }^{\circledR}$ para coliformes totais e $E$. coli}

O método SimPlate ${ }^{\circledR}$ para contagem de coliformes totais e E. coli é baseado na tecnologia de substrato definido que correlaciona a presença de coliformes totais e $E$. coli com a presença de beta-galactosidase e beta-glucoronidase, respectivamente. $\mathrm{O}$ composto vermelho clorofenol b-D-galactopiranosídeo (CPRG), quando hidrolisado pela enzima b-galactosidase, produz o composto vermelho clorofenol (CPR) que possui coloração laranja a púrpura e o composto 4-metilumbeliferil b-d-glucoronídeo (MUG) quando hidrolizado pela enzima beta-glucoronidase produz o 4-metilumbeliferona (4UM) que apresenta cor azul fluorescente quando exposto a UV a 365nm (Hajdenwurcel, 1998).

O número de cavidades coloridas (laranja a púrpura) em cada placa é 
registrado como positivo para coliformes. As cavidades que fluorescem azul quando expostas a comprimento de onda ultravioleta $(365 \mathrm{~nm})$ são registradas como positivas para E. coli. O número de cavidades positivas é convertido em Número Mais Provável (NMP) de coliformes ou E. coli (Townsend et al., 1998).

\subsubsection{Kits rápidos para deteç̧ão de Salmonella}

Foram surgindo no mercado vários kits rápidos eficientes, merecendo destaque o 1-2 Test e o Salmonella Rapid Test. Os dois kits permitem uma rápida e precisa detecção da Salmonella.

\subsubsection{O kit 1-2 Test da BioControl}

O 1-2 Test da BioControl é um método rápido qualitativo para a detecção das espécies móveis de Salmonella. Os resultados estarão disponíveis em 2 dias, o que significa grande ganho de tempo, comparando com o método tradicional. Trata-se de um método aprovado pela AOAC (Association of Official Analytical Chemists International) para utilização em todos os tipos de alimentos.

O princípio se baseia na observação da imobilização da Salmonella pelos anticorpos polivalentes $\mathrm{H}$ (flagelar) contidos no meio de motilidade, com o desenvolvimento de uma banda visual bem definida (imunobanda).

A unidade teste é composta por dois compartimentos: câmara de inoculação, contendo caldo tetrationato-verde brilhante, e a câmara de motilidade, contendo um meio de motilidade não seletivo à base de peptona. A comunicação entre os compartimentos é vedada por um tampão, que deve ser removido antes da adição da amostra. Durante a incubação do kit inoculado, a Salmonella contida no caldo tetrationato-verde brilhante se move da câmara de inoculação para o meio de motilidade para reagir com os anticorpos, formando a imunobanda. 


\subsubsection{O kit Salmonella Rapid Test da Oxoid}

O Salmonella Rapid Test da Oxoid, é um método baseado no uso de 2 tubos onde no tubo A encontram-se os meios de cultivo Lisina Ferro Cistina Vermelho Neutro (indicador) e Rappaport Vassiliadis Modificado (seletivo). A enzima cistinadisulfohidrase hidrolisa a cistina com fomação de ácido pirúvico, amônia e ácido sulfídrico. O ácido sulfídrico se combina com o ferro formando o sulfeto de ferro de cor preta, podendo passar para o compartimento inferior.

No tubo B estão presentes os meios de cultivo Verde Brilhante Modificado (indicador) e Lisina Ferro Desoxicolato Modificado (seletivo). Neste tubo há a descarboxilação da lisina com a formação de ácido sulfídrico que se combina com o ferro, formando o sulfeto de ferro enegrecendo o compartimento inferior. A cor negra pode passar para o compartimento superior. No compartimento superior, a Salmonella não fermenta lactose (LAC) nem sacarose (SAC). Há a formação de compostos alcalinos e o indicador do meio (vermelho fenol) se manifesta deixando o meio vermelho.

Como qualquer método rápido microbiológico, se der negativo, não tem o microrganismo-alvo. Se der positivo (nos dois tubos ou em um tubo), confirmar com a prova sorológica (Salmonella Látex Test), através de reação de aglutinação frente a um anti-soro específico para Salmonella.

\subsection{Tratamentos térmicos utilizados no leite}

Dentre os vários processos industriais visando à conservação do leite destacam-se: pasteurização, esterilização, evaporação, condensação, desidratação e fermentações. No presente trabalho será dada ênfase à pasteurização.

\subsubsection{Pasteurização e sua importância}

A pasteurização do leite tem se constituído, de longa data, em valiosa arma na prevenção de zoonoses disseminadas por esse alimento. Este processo de pasteurização, 
mesmo quando eficiente na destruição dos agentes patogênicos, não é capaz de eliminar todos os microrganismos presentes no produto (Ajzental et al., 1996).

A pasteurização do leite pode ser efetuada de várias maneiras ou processos, utilizando-se dos mais variados tipos de equipamentos. Deve-se, no entanto ater aos objetivos da pasteurização, que é a eliminação total dos microrganismos patogênicos presentes no leite e a redução no número de microrganismos não patogênicos, conhecidos como microbiota banal (Sbampato, 1998).

Segundo Souza \& Cerqueira (1996) a eficiência do processo de pasteurização relaciona-se com a destruição de quase toda a microbiota banal do leite (97\%) e de $100 \%$ da flora patogênica, sem alterações da composição, equilíbrio físico-químico, sabor e odor do produto. A despeito de estarem estabelecidos internacionalmente os valores binômio temperatura-tempo de pasteurização, a variabilidade e a quantidade da microbiota bacteriana do leite constituem-se de fatores capazes de influir na qualidade do produto pasteurizado (Pelczar et al., 1996; Souza \& Cerqueira, 1996).

O leite pasteurizado deve ser classificado quanto ao teor de gordura como integral, padronizado a $3 \%(\mathrm{~g} / 100 \mathrm{~g})$, semidesnatado ou desnatado, e, quando destinado ao consumo humano direto na forma fluida, submetido a tratamento térmico na faixa de temperatura de 72 a $75^{\circ} \mathrm{C}$ durante 15 a 20 s, em equipamento de pasteurização, dotado de painel de controle com termo-registrador e termo-regulador automáticos, válvula automática de desvio de fluxo, termômetros e torneiras de prova, seguindo-se de resfriamento imediato até temperatura igual ou inferior a $4^{\circ} \mathrm{C}$ e envase em circuito fechado no menor prazo possível, sob condições que minimizem contaminações( Pelczar et al., 1996).

Os processos de pasteurização, UHT e ultrafiltração originam produtos lácteos livres de microrganismos patogênicos. Estes tratamentos térmicos garantem a ausência de Salmonella, Campylobacter, Staphylococcus, Brucella, Yersinia, Shigella, Pseudomonas, Listeria, Coxiella, Corynebacterum, Streptococcus, desde que as tecnologias envolvidas para o processamento sejam rigorosamente cumpridas (Ajzental, 1994).

A taxa de redução microbiana do processo de pasteurização rápida (HTST) 
para leite beneficiado em entrepostos, usinas (tipo C) e em granjas leiteiras (tipo A) foi maior $(\mathrm{p}>0,05)$ do que a do leite submetido à pasteurização lenta (LTLT) em banhomaria (integral/fazenda) (Souza \& Cerqueira, 1996).

Segundo Furtado (1988) e Sbampato (1998), o leite pasteurizado pelo sistema ejetor de vapor apresentou teores mais elevados de ácidos graxos livres, os glóbulos de gordura apresentaram-se menos aglomerados, o soro apresentou menor perda de gordura, além do maior rendimento de fabricação $\mathrm{L}$ de leite/ $\mathrm{Kg}$ de queijo, quando comparado com a pasteurização pelo sistema HTST.

\subsubsection{Pontos críticos de controle no leite pasteurizado}

Análise de Perigos e Pontos Críticos de Controle (APPCC), é um sistema de análise que identifica perigos específicos e medidas preventivas para seu controle, objetivando a segurança do alimento, e contempla para a aplicação, nas indústrias sob inspeção do SIF, também os aspectos de garantia de qualidade. Baseia-se na prevenção, eliminação ou redução dos perigos em todas as etapas da cadeia produtiva. Constitui-se de sete princípios básicos como a identificação do perigo; identificação do ponto crítico; estabelecimento do limite crítico; monitorização; ações corretivas; procedimentos de verificação e registros dos resultados (Franco \& Landgraf, 1996; Hajdenwurcel et al., 2002).

Os Pontos de Controle Críticos (PCC), definidos na análise, serão aqueles pontos do processo onde a aplicação de uma medida de controle elimina ou reduz o perigo a um nível aceitável, ou seja, onde não signifique um problema de saúde para o consumidor. Uma boa análise de perigos nos facilitará determinar as etapas realmente críticas para a inocuidade do produto, já que na prática o ideal é mantê-los em um mínimo, de forma que possa dar a máxima atenção às medidas preventivas essenciais para a inocuidade (Franco \& Landgraf, 1996; Hajdenwurcel et al., 2002).

No momento da chegada do leite cru à indústria é imprescindível uma criteriosa seleção deste produto, devendo o mesmo ser conservado em tanque de estocagem a $5^{\circ} \mathrm{C}$ ou menos. Como esta temperatura não é capaz de eliminar o perigo 
microbiológico, mas apenas reduzí-lo a níveis aceitáveis, evitando a multiplicação da maioria das bactérias patogênicas, a conservação do leite no tanque de estocagem é considerada um ponto crítico de controle parcialmente eficaz (PCC2) (Figura 1). O processo de pasteurização, por sua vez, é um ponto crítico de controle totalmente eficaz (PCC1) (Figura 1), pois destrói as bactérias patogênicas, eliminando o perigo microbiológico. O conhecimento de que a pasteurização não é capaz de eliminar todas as toxinas, enzimas e esporos microbianos que podem estar presentes no leite cru leva a propor que outros PCCs antes e após este tratamento térmico, devem ser controlados, bem como a temperatura de refrigeração durante a estocagem do produto (Lopez \& Stamford, 1997).

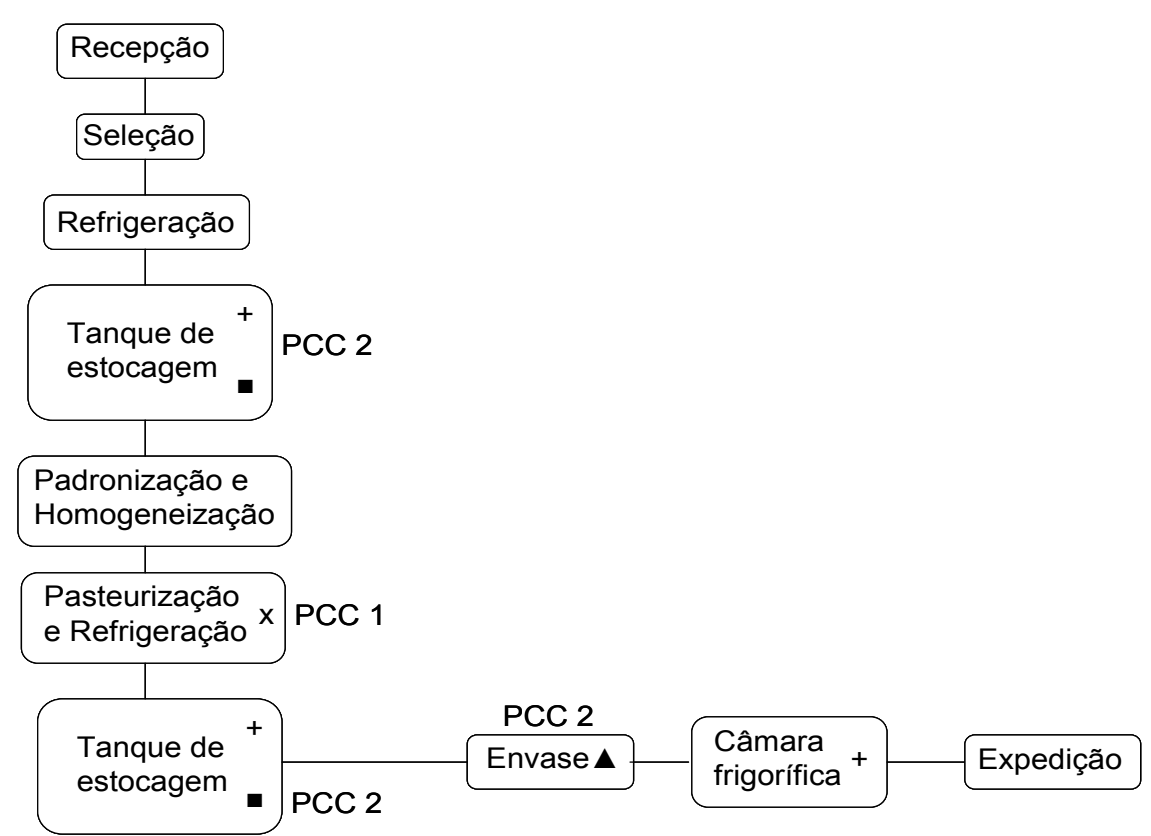

Fonte: Lopez \& Stamford, 1997

Figura 1 - Fluxograma de beneficiamento do leite pasteurizado, evidenciando os pontos críticos de controle parcialmente eficaz (PCC2) e o totalmente eficaz (PCC1). Observam-se pontos importantes de contaminação (घ), pontos de contaminação pouco importantes $(\boldsymbol{\Delta})$, pontos de possível multiplicação de microrganismos $(+)$ e pontos de destruição térmica $(\mathrm{x})$ 


\subsection{Classificação do leite}

A classificação do leite elaborada pelo Ministério da Agricultura, Pecuária e Abastecimento - DIPOA (Departamento de Inspeção de Produtos de Origem Animal), através da Instrução Normativa $n^{\circ} 51$, de 18 de Setembro de 2002, estabelece:

\section{Leite Tipo A}

Produzido em granja leiteira, com rebanho acompanhado por veterinário do Serviço de Inspeção. Deve ser pasteurizado e resfriado imediatamente após a ordenha, que obrigatoriamente é mecânica. Imediatamente após a pasteurização o produto assim processado deve apresentar teste qualitativo negativo para fosfatase alcalina e teste positivo para peroxidase. O leite deve ser resfriado e transportado à temperatura de $4^{\circ} \mathrm{C}$.

O leite A pode ser dividido em:

- Leite Pasteurizado tipo A Integral;

- Leite Pasteurizado tipo A Padronizado;

- Leite Pasteurizado tipo A Semidesnatado;

- Leite Pasteurizado tipo A Desnatado;

\section{Leite Tipo B}

Produzido em estábulo leiteiro, com rebanho acompanhado por veterinário do Serviço de Inspeção. Após a ordenha pode ser resfriado e transportado para ser pasteurizado em usinas de beneficiamento ou entreposto-usina, num período de 3 horas após a ordenha. Este prazo pode ser prolongado por mais 2 horas, desde que o leite tenha sido resfriado à temperatura de $7^{0} \mathrm{C}$. Imediatamente após a pasteurização, o produto assim processado deve apresentar teste qualitativo negativo para fosfatase alcalina e teste positivo para peroxidase.

O leite B pode ser dividido em:

- Leite cru Refrigerado tipo B;

- Leite Pasteurizado tipo B Integral; 
- Leite Pasteurizado tipo B Padronizado;

- Leite Pasteurizado tipo B Semidesnatado;

- Leite Pasteurizado tipo B Desnatado.

\section{Leite tipo C}

O leite cru tipo $\mathrm{C}$ é transportado em vasilhame adequado e individual de capacidade até 50 litros e entregue em estabelecimento industrial adequado até as 10:00 $\mathrm{h}$ do dia de sua obtenção, em temperatura ambiente. Após ser entregue em posto de refrigeração de leite ou estabelecimento industrial adequado, é mantido em temperatura igual ou inferior a $4^{\circ} \mathrm{C}$. Este leite, após sofrer refrigeração em posto de refrigeração, permanece estocado no período máximo de $24 \mathrm{~h}$, sendo remetido em seguida ao estabelecimento beneficiador. Em um período máximo de 12 h, o leite é transportado para outra indústria, visando processamento final, onde deve apresentar, no momento do seu recebimento, temperatura igual ou inferior a $7^{\circ} \mathrm{C}$. Imediatamente após a pasteurização, o produto assim processado deve apresentar teste negativo para fosfatase alcalina e teste positivo para peroxidase.

O leite tipo C é dividido em:

- Leite cru tipo C;

- Leite cru Refrigerado tipo C;

- Leite Pasteurizado tipo C Integral;

- Leite Pasteurizado tipo C Padronizado;

- Leite Pasteurizado tipo C Semidesnatado;

- Leite Pasteurizado tipo C Desnatado. 


\section{MATERIAL E MÉTODOS}

\subsection{Amostragem}

As amostras de leite pasteurizado dos tipos A, B e C, foram obtidas em diferentes pontos de venda no município de Piracicaba-SP. As coletas foram efetuadas em estabelecimentos comerciais de pequeno, médio e grande portes, em diferentes bairros com alternância a cada amostra. Foram coletadas 3 amostras para cada uma das 3 marcas de leite para cada tipo do produto. Essas amostras sofreram uma nova pasteurização no Laboratório de Microbiologia de Alimentos do Departamento de Agroindústria, Alimentos e Nutrição da ESALQ-USP, para se verificar a eficiência deste tratamento térmico, quando comparado a pasteurização industrial aplicada às amostras coletadas.

Também foi avaliada a qualidade microbiológica do leite cru, valendo ressaltar que nos locais de coleta das amostras de leite pasteurizado, não é comercializado o produto cru.

\subsection{Metodologia}

As amostras foram analisadas de acordo com a metodologia padrão descrita por: Vanderzant \& Splittstoesser, 1992 e Association of Official Analytical Chemists (AOAC, 2000). 


\subsection{Preparo das amostras}

As análises foram realizadas no Laboratório de Microbiologia de Alimentos do Departamento de Agroindústria, Alimentos e Nutrição da ESALQ-USP.

Foram analisadas 9 amostras de leite pasteurizado tipo A, 9 amostras de leite pasteurizado tipo B, 9 amostras de leite pasteurizado tipo C e 3 amostras de leite cru, totalizando 30 amostras.

Para todas as amostras foram realizadas análises microbiológicas para contagem total de bactérias psicrotróficas, mesófilas, termófilas; coliformes totais e fecais (NMP); coliformes totais e E. coli (SimPlate); contagem de Staphylococcus coagulase positiva e análise para Salmonella. Após a retirada da alíquota necessária para tais análises, procedeu-se a pasteurização do restante do leite de cada amostra. Essa pasteurização foi realizada em banho-maria a 62,8 $8^{\circ} \mathrm{C} / 30^{\prime}$ (Figura 2), e novamente todos os parâmetros microbiológicos mencionados foram analisados. Tal procedimento teve o objetivo de avaliar a eficácia do processo de pasteurização industrial que as amostras haviam sofrido, bem como avaliar os efeitos benéficos de tal tratamento térmico nas amostras de leite cru. Assim, foram analisadas 30+30, ou seja, um total de 60 amostras de leite.

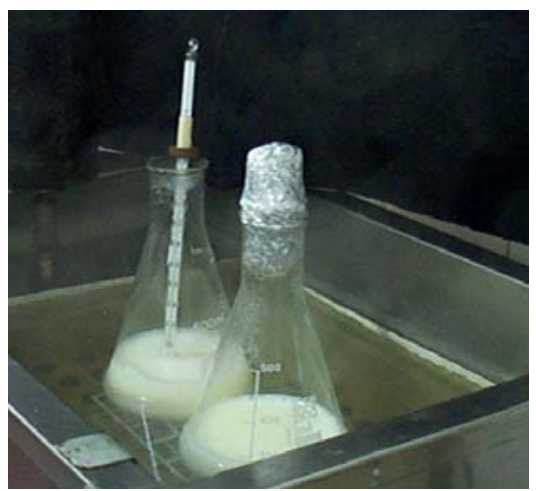

Figura 2 - Pasteurização no laboratório em banho-maria a $62,8^{\circ} \mathrm{C} / 30^{\prime}$ 
As amostras, ao chegarem ao laboratório, foram homogeneizadas na própria embalagem para que os microrganismos se distribuíssem uniformemente. As embalagens foram desinfetadas externamente com álcool etílico a 70\%. Foram abertas e transferidas para erlenmeyer esterilizado, a fim de facilitar o preparo das diluições e a pasteurização no laboratório.

Foram utilizados $50 \mathrm{~mL}$ de cada amostra de leite colocados em frascos erlenmeyer previamente esterilizados, contendo $450 \mathrm{~mL}$ de água peptonada $0,1 \%$ esterilizada, obtendo-se assim, a diluição $10^{-1}$. A partir dessa diluição, foram feitas diluições em série até a obtenção da diluição $10^{-5}$ (Figura 3 ).

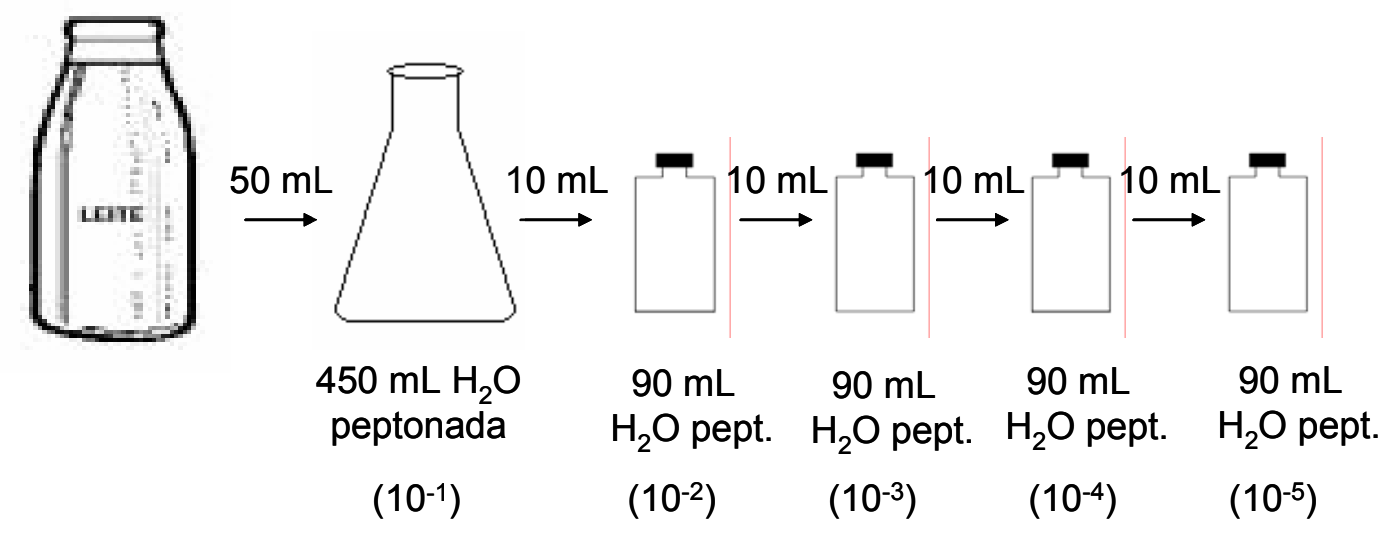

Figura 3 - Preparo de diluições em série

\subsection{Contagem total de microrganismos aeróbios mesófilos, termófilos e psicrotróficos}

A partir das amostras sem diluição e das diluições $10^{-1}, 10^{-2}, 10^{-3}, 10^{-4}$ e $10^{-5}$ realizou-se plaqueamento em profundidade em PCA (Agar Padrão de Contagem), utilizado para contagem dos grupos microbianos, aeróbios mesófilos, psicrotróficos e termófilos, com incubação a $35^{\circ} \mathrm{C} / 48 \mathrm{~h}, 7^{\circ} \mathrm{C} / 10$ dias e $50^{\circ} \mathrm{C} / 48 \mathrm{~h}$, respectivamente (Figura 4). Transcorrido o tempo de incubação fez-se a contagem do número de colônias, com o auxílio de um contador de colônias (Phoenix EC-589); multiplicou-se a média aritmética das duplicatas pelo respectivo fator de diluição. Os resultados foram expressos em $\mathrm{UFC} / \mathrm{mL}$ de leite. 


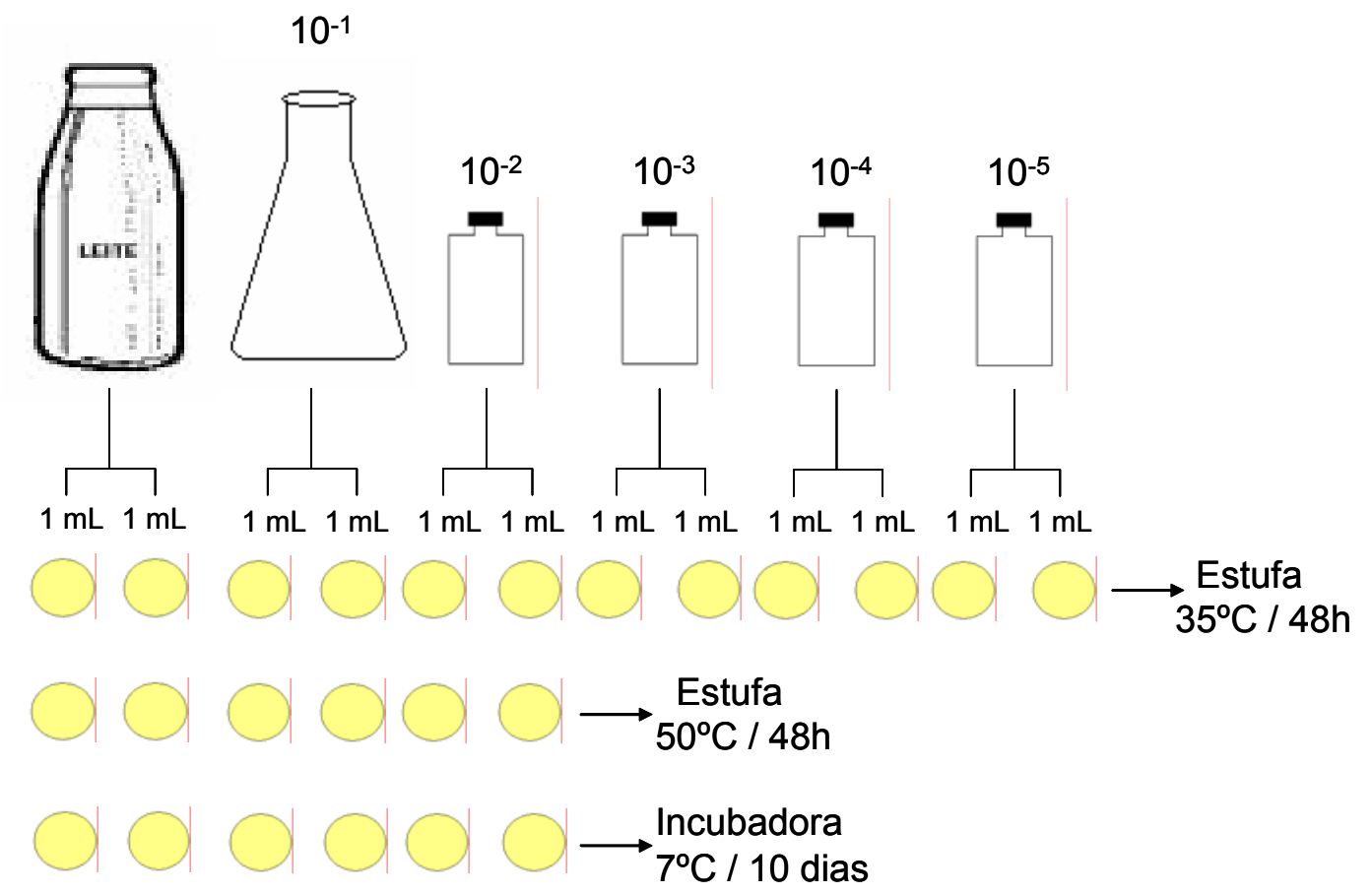

Figura 4 - Procedimento para o plaqueamento e a contagem total de mesófilos, termófilos e psicrotróficos

\subsection{Número Mais Provável de coliformes totais e fecais}

De acordo com a metodologia de Vanderzant \& Splittstoesser (1992), alíquotas de $1 \mathrm{~mL}$ das diluições $10^{-1}, 10^{-2}, 10^{-3}$ foram transferidas para $10 \mathrm{~mL}$ de Caldo Verde Brilhante Lactose Bile(CVBLB 2\%) em 3 séries de 5 tubos (contendo tubo de Duhram) (Figura 5) que foram incubados por $24 / 48$ horas a $35^{\circ} \mathrm{C}$ para o teste confirmativo de coliformes totais (Figuras 5 e 6). Após a incubação dos mesmos, foram observados tubos que apresentaram produção de gás, dos quais com auxílio de alça níquel-cromo foram retiradas alíquotas e transferidas para tubos com caldo EC (contendo tubo de Duhram) e incubados por 24 horas a $45^{\circ} \mathrm{C}$ para o teste confirmativo de coliformes fecais (Figuras 5 e 6). Mediante a consulta à Tabela de Hoskins (1933) citado por Peeler et al. (1992), foi calculado o Número Mais Provável de coliformes totais e fecais por mililitro de leite para cada amostra. 
Segundo a norma da ABNT (MB-3463 de 1991), há um ressalvo nessa técnica para produtos lácteos, onde a prova presuntiva não é efetuada, sendo as inoculações realizadas diretamente em CVBLB 2\% que é um meio de cultivo bastante seletivo devido à presença de verde brilhante e sais biliares. Portanto, o meio inibe o crescimento de microrganismos Gram-positivos e oferece condições de desenvolvimento para microrganismos mais adaptados às condições gastrintestinais, favorecendo o crescimento de bactérias do grupo coliforme, que utilizam a lactose presente no meio resultando na produção de gás.
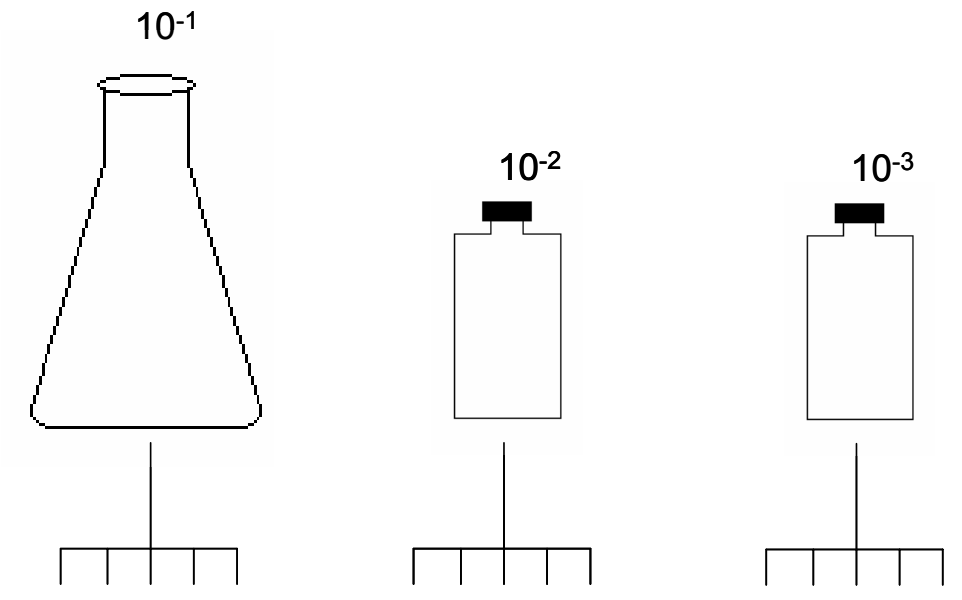

$1 \mathrm{~mL}$ em cada tubo $1 \mathrm{~mL}$ em cada tubo $1 \mathrm{~mL}$ em cada tubo

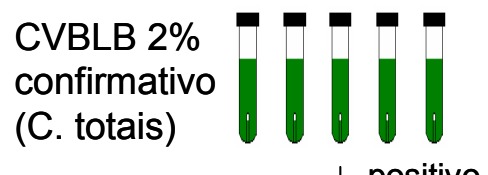

(C. totais)

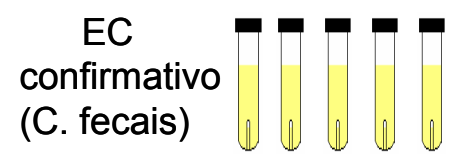

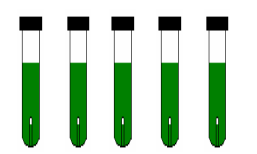

| positivo
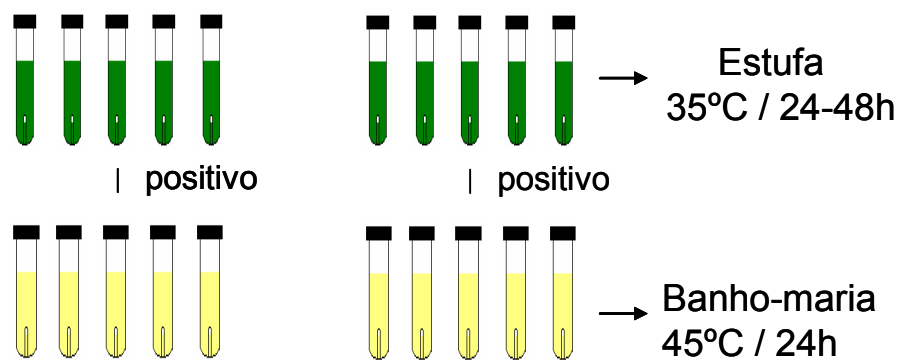

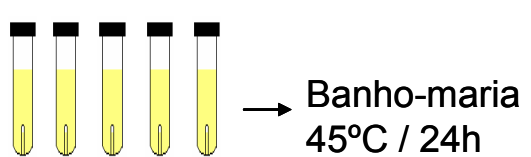

Figura 5 - Procedimento para a estimativa do NMP de coliformes totais e fecais 


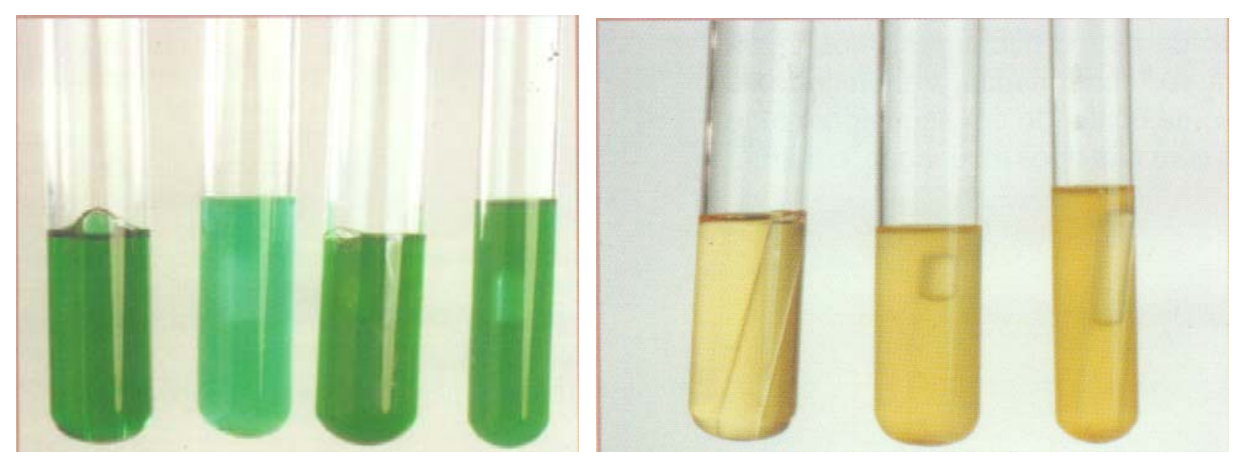

Fonte: Hajdenwurcel, 1998

Figura 6 - Teste confirmativo para coliformes totais em CVBLB a $35^{\circ} \mathrm{C}$ e confirmativo para coliformes fecais a $45^{\circ} \mathrm{C}$ em caldo EC

\subsection{Numero Mais Provável de coliformes totais e $E$. coli pelo sistema SimPlate ${ }^{\circledR}$}

As placas foram inoculadas usando diluições $10^{0}$ e $10^{-1}$. Foi inoculado $1 \mathrm{~mL}$ das diluições no centro da placa e adicionados $9 \mathrm{~mL}$ de meio de cultura específico para coliformes totais e E. coli. As placas foram homogeneizadas e o excesso de meio de cultura descartado; a seguir foram invertidas e incubadas a $35^{\circ} \mathrm{C}$ por 24 horas. Após o período de incubação, as cavidades das placas que apresentavam coloração de laranja à púrpura eram contadas para a estimativa do NMP de coliformes totais. A seguir, as placas eram expostas à luz UV(365nm) e as cavidades que apresentavam fluorescência eram contadas para a estimativa do NMP de E. coli (Figura 7). O número de cavidades positivas presentes no SimPlate ${ }^{\circledR}$ foi transformado em NMP de coliformes totais e E.coli/mL de leite, através de consulta à Tabela própria do método. 

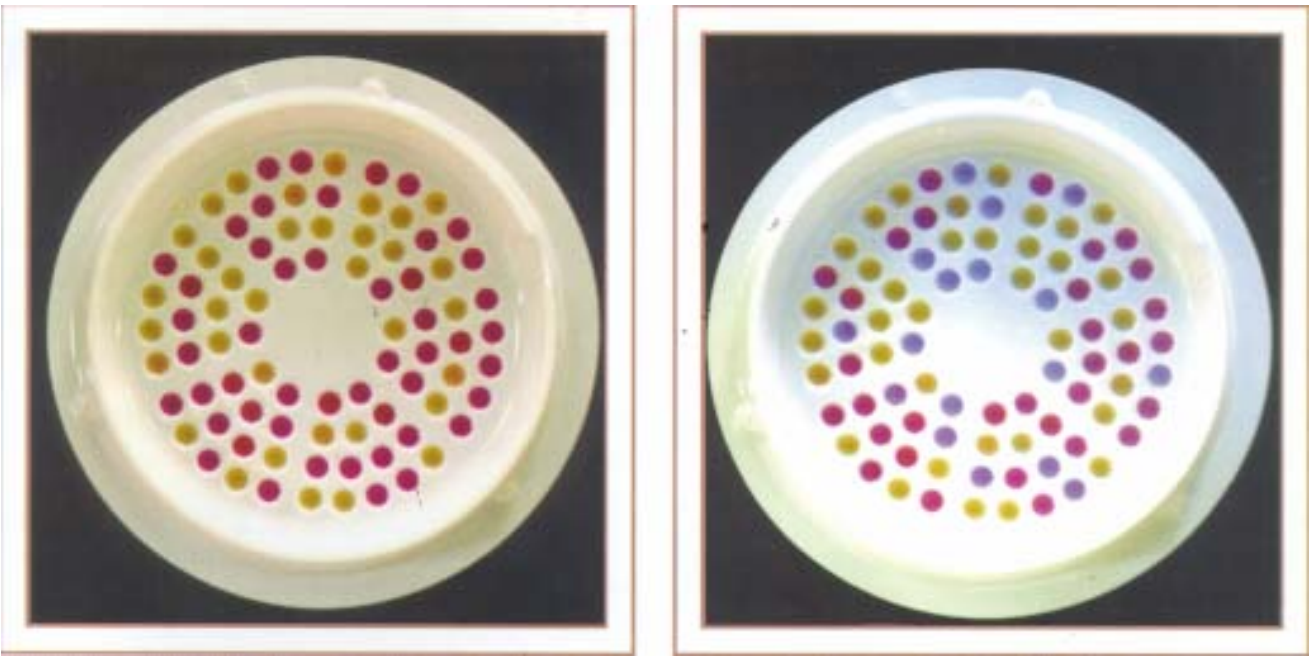

Fonte: Hajdenwurcel, 1998

Figura 7 - Placas de SimPlate ${ }^{\circledR}$ mostrando teste positivo para coliformes totais (cor púrpura) e E. coli (azul fluorescente)

\subsection{Análise estatística}

Para a análise estatística, as contagens foram transformadas em logarítmo de base $10(\log X+2)$. Foi utilizada análise de regressão linear simples para comparação dos métodos de NMP (tubos múltiplos) e SimPlate ${ }^{\circledR}$ (SAS, 1996). A análise de regressão é um sistema freqüentemente utilizado para descrever relação entre dois métodos (McAllister et al., 1987). Para esta análise estatística, os critérios tradicionais de equivalência entre os dois métodos são coeficiente angular próximo de 1,0; coeficiente linear próximo de zero e coeficiente de correlação >0,9 (Matner et al., 1990).

\subsection{Contagem de Staphylococcus coagulase positiva}

Para a detecção de Staphylococcus coagulase positiva foi utilizado o método de contagem direta em placas, com semeadura em superfície e espalhamento com alça de Drigalsky descrito por Vanderzant \& Splittstoesser (1992). 
A partir da amostra pura, alíquotas de $0,4+0,3+0,3 \mathrm{~mL}$, totalizando $1 \mathrm{~mL}$, foram espalhadas. Também a partir da amostra pura, bem como das diluições $10^{-1}$ e $10^{-2}$, alíquotas de 0,1 mL foram inoculadas e espalhadas com alça de Drigalsky (Figura 8). Todas essas alíquotas foram espalhadas em meio Agar Baird-Parker (BPA), em placas de Petri previamente preparadas. Após o espalhamento e secagem completa do inóculo, as placas foram invertidas e incubadas a $35-37^{\circ} \mathrm{C} / 24-48 \mathrm{~h}$.

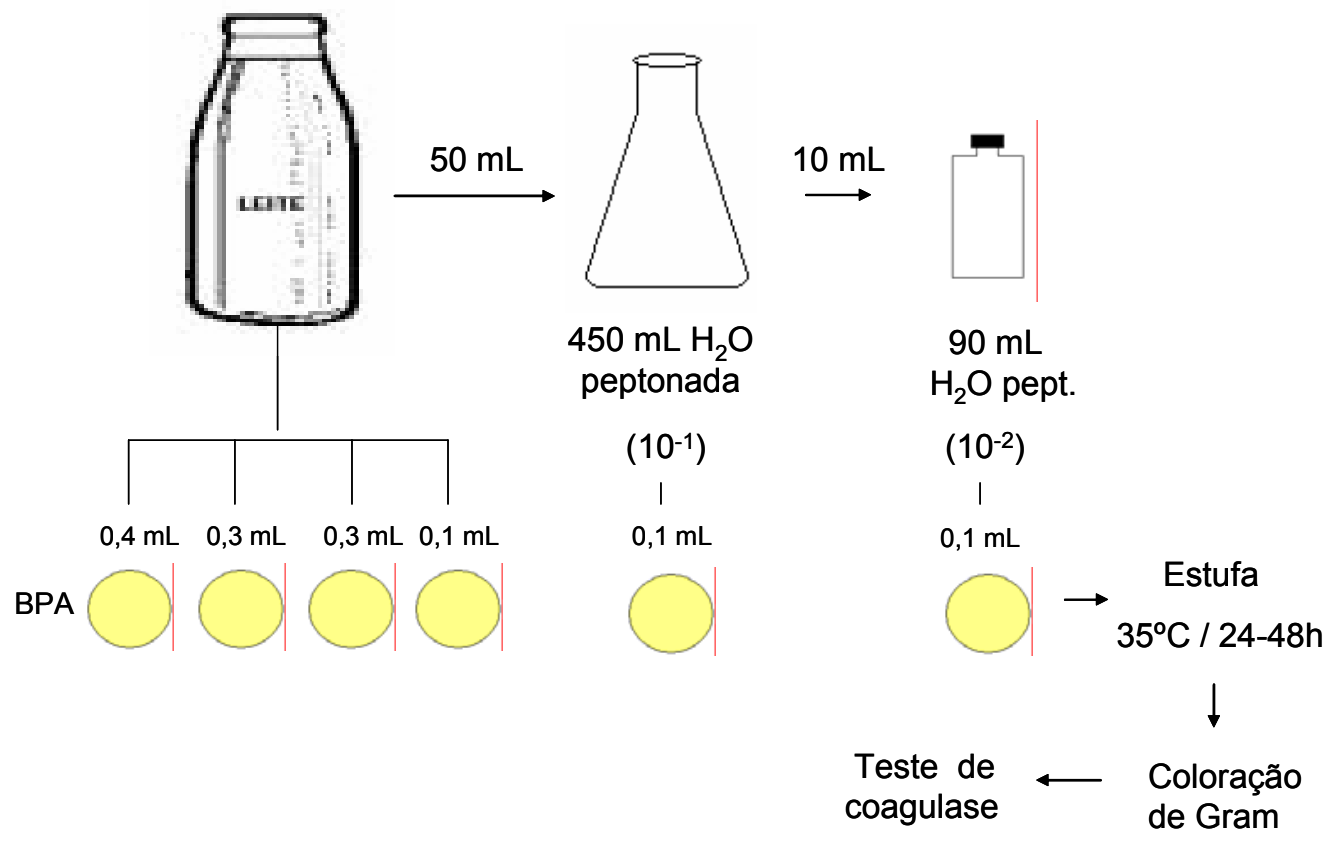

Figura 8 - Preparo para a contagem e o isolamento de Staphylococcus coagulase positiva

Para a contagem presuntiva utilizaram-se todas as placas contendo 20 a 200 colônias e com o auxílio de um microscópio estereoscópico foram contadas as colônias típicas, ou seja, colônias pretas (devido a redução do telurito de potássio a telureto), circulares, pequenas, com bordas perfeitas, lisas, convexas, rodeadas por uma zona opaca e/ou um halo transparente (lecitinase positiva) (Figura 9). Eventualmente, as colônias atípicas, porém suspeitas, também foram selecionadas para o teste de produção de coagulase. Normalmente estas colônias são pretas, lustrosas, de forma irregular sem halo opaco ou transparente, podendo ser colônias de S. epidermidis. Podem aparecer 
colônias pequenas, pretas e sem halo de clarificação que são características de Micrococos. Também leveduras e Bacillus, eventualmente podem crescer neste meio, porém as colônias são pardo-escuras e brancas, respectivamente, não sendo nesse caso selecionadas para a realização da prova de coagulase.

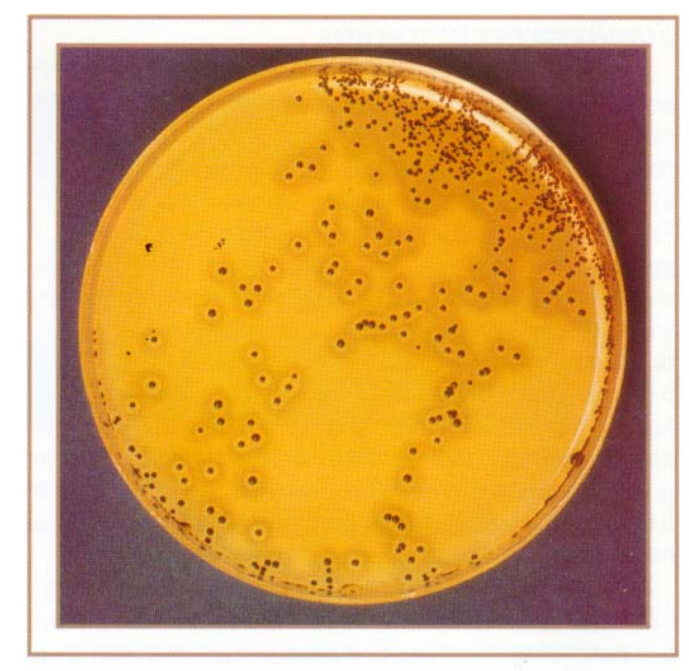

Fonte: Hajdenwurcel, 1998

Figura 9 - Colônias típicas de Staphylococcus coagulase positiva em meio BPA

Para o teste de coagulase, retirou-se a colônia típica ou suspeita do meio BPA com o auxílio de uma alça níquel-cromo, inoculando-a em tubo estéril de hemólise com 0,5mL de coagu-plasma. A alçada das colônias típicas ou suspeitas de Staphylococcus foi dissolvida, atritando a ponta da alça nas paredes do tubo inclinado em mais ou menos $45^{\circ}$. Os tubos foram incubados a $37^{\circ} \mathrm{C} / 4 \mathrm{~h}$ (ou até no máximo 24 horas) procurando a formação de coágulo, que caracteriza positividade da prova.

O cálculo da população de Staphylococcus coagulase positiva foi realizado através da contagem em placas das colônias típicas ou suspeitas e selecionadas, as quais apresentaram resultados positivos com coagulação do plasma sanguíneo. 


\subsection{Análise de Salmonella}

Para a análise de Salmonella, (Figura 10) as amostras foram submetidas a um pré-enriquecimento, onde foram pipetados $25 \mathrm{~mL}$ de cada amostra de leite e transferidos para um erlenmeyer contendo $225 \mathrm{~mL}$ de caldo lactosado esterilizado. As amostras assim diluídas foram homogeneizadas e incubadas a $37^{\circ} \mathrm{C}$ por $24 \mathrm{~h}$.

Para a detecção de Salmonella spp. foi utilizado o kit rápido 1-2 Test, da BioControl. Trata-se de um método aprovado pela Association of Official Analytical Chemists (AOAC, 2000), qualitativo para detecção das espécies móveis de Salmonella.

Uma alíquota de $0,1 \mathrm{~mL}$ da amostra pré-enriquecida em Caldo Lactosado foi inoculada na câmara de inoculação. O "tip" presente na tampa da câmara de motilidade, o qual forma um vão no gel, foi retirado para a adição da solução de anticorpos. Posteriormente, o kit inoculado com a amostra foi incubado por $14-30$ horas a $35^{\circ} \mathrm{C}$, para poder ser observada ou não a formação da imunobanda.

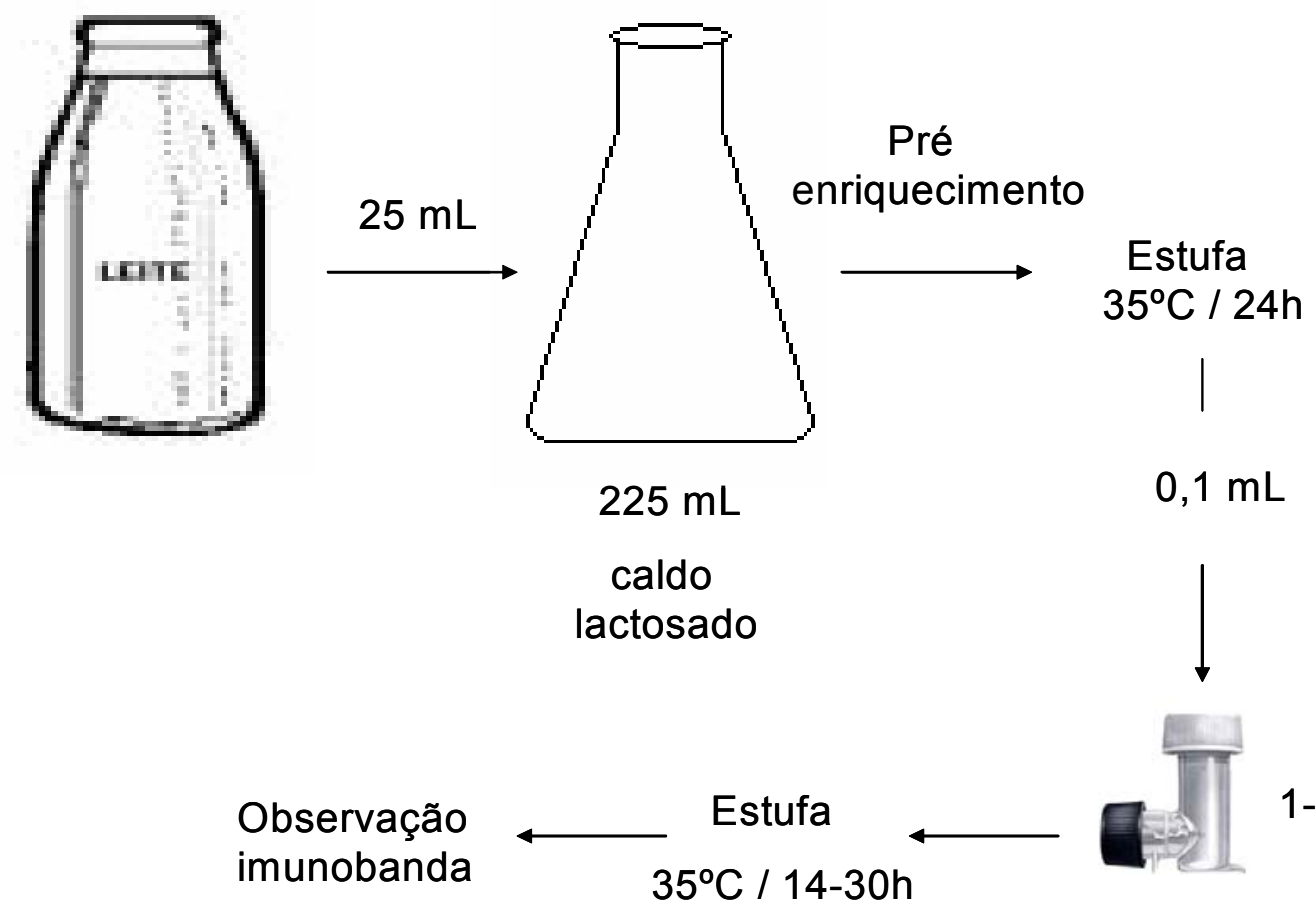

Figura 10 - Procedimento para a análise de Salmonella usando o kit 1-2 test da Biocontrol 


\section{RESULTADOS E DISCUSSÃO}

\subsection{Padrões microbiológicos}

Os resultados de todas as análises realizadas foram comparados com os padrões microbiológicos previstos pela legislação brasileira, para os diferentes tipos de leite.

Os padrões microbiológicos do leite foram baseados no Ministério da Agricultura, Pecuária e Abastecimento, através do Regulamento de Inspeção Industrial e Sanitária de Produtos de Origem Animal (RIISPOA), aprovado pelo decreto n.30.691, de 29/03/52; alterado pelo decreto n. 1.255 de 25/06/62 (Brasil, 1980). Esse padrão foi usado no presente trabalho, para verificar as mudanças da legislação em comparação com as legislações do DIPOA (Brasil, 2002) e ANVISA (Brasil, 2001), as quais estão em vigor.

Os padrões microbiológicos para leite estabelecidos pelo Departamento de Inspeção de Produtos de Origem Animal (DIPOA) encontram-se na Instrução Normativa $n^{0} 51$ de 18/09/02 (Brasil, 2002) e os da Agência Nacional de Vigilância Sanitária ANVISA, na Resolução RDC n ${ }^{\circ} 12$ de 02/01/01 do Ministério da Saúde (Brasil, 2001).

Os 3 padrões microbiológicos citados e que foram utilizados na presente pesquisa para avaliação das condições microbiológicas das amostras de leite analisadas, encontram-se nas Tabelas 1, 2 e 3. 
Tabela 1. Padrões microbiológicos para o leite tipo A, B e demais tipos

\begin{tabular}{|c|c|c|c|c|c|c|}
\hline \multirow[t]{3}{*}{ Microrganismos } & \multicolumn{6}{|c|}{ Leite } \\
\hline & \multicolumn{2}{|c|}{ A } & \multicolumn{2}{|c|}{ B } & \multicolumn{2}{|c|}{ Demais Tipos } \\
\hline & $\begin{array}{l}\text { Antes da } \\
\text { Past }\end{array}$ & Após Past & $\begin{array}{c}\text { Antes da } \\
\text { Past }\end{array}$ & Após Past & $\begin{array}{c}\text { Antes da } \\
\text { Past }\end{array}$ & Após Past \\
\hline $\begin{array}{c}\text { Contagem Total de } \\
\text { Mesófilos } \\
\text { (UFC/mL) }\end{array}$ & $1,0 \times 10^{4}$ & $5,0 \times 10^{2}$ & $5,0 \times 10^{5}$ & $4,0 \times 10^{4}$ & - & $1,5 \times 10^{5}$ \\
\hline $\begin{array}{l}\text { Coliformes Fecais } \\
(\mathrm{NMP} / \mathrm{mL})\end{array}$ & \multicolumn{2}{|c|}{ Ausência em $1 \mathrm{~mL}$} & \multicolumn{2}{|c|}{1} & \multicolumn{2}{|c|}{5} \\
\hline Salmonella $(25 \mathrm{~mL})$ & \multicolumn{2}{|c|}{ Ausência } & \multicolumn{2}{|c|}{ Ausência } & Ausência & \\
\hline
\end{tabular}

Fonte: RIISPOA (Regulamento de Inspeção Industrial de Produtos de Origem Animal), 1980

Tabela 2. Padrões microbiológicos para o leite tipo A, B e C

\begin{tabular}{lccc}
\hline Microrganismos & \multicolumn{3}{c}{ Leite } \\
& A & B & C \\
\hline $\begin{array}{c}\text { Contagem padrão em } \\
\text { Placas (UFC/mL) }\end{array}$ & $1,0 \times 10^{3}$ & $8,0 \times 10^{4}$ & $3,0 \times 10^{5}$ \\
$\begin{array}{c}\text { Coliformes Totais } \\
(\mathrm{NMP} / \mathrm{mL})\end{array}$ & $<1$ & 5 & 4 \\
$\begin{array}{c}\text { Coliformes Fecais } \\
(\mathrm{NMP} / \mathrm{mL})\end{array}$ & Ausência & 2 & 2 \\
Salmonella $(25 \mathrm{~mL})$ & Ausência & Ausência & Ausência \\
\hline
\end{tabular}

Fonte: DIPOA (Departamento de Inspeção de Produtos de Origem Animal), 2002

Tabela 3. Padrões microbiológicos para leite pasteurizado (todos os tipos)

\begin{tabular}{cc}
\hline Microrganismos & Leite Pasteurizado \\
\hline Coliformes a $45^{\circ} \mathrm{C}(\mathrm{NMP} / \mathrm{mL})$ & $1-4$ \\
Salmonella $(25 \mathrm{~mL})$ & Ausência \\
\hline
\end{tabular}

Fonte: ANVISA (Agência Nacional de Vigilância Sanitária), 2001

\subsection{Contagem total de aeróbios mesófilos, termófilos e psicrotróficos}

Após a incubação a $35^{\circ} \mathrm{C} / 48 \mathrm{~h}$ (mesófilos), $7^{\circ} \mathrm{C} / 10$ dias (psicrotróficos) e $50^{\circ} \mathrm{C} / 48 \mathrm{~h}$ (termófilos) realizou-se a contagem de colônias para as amostras de leite pasteurizado tipos A, B, C e leite cru antes e após a pasteurização em laboratório (Tabela 4). Também foi feita a média das contagens para os tipos de leite analisados e os valores foram transformados $(\log x+2)$ (Figura 11) para melhor visualização dos dados. 
Tabela 4. Contagens totais de aeróbios mesófilos, termófilos e psicrotróficos pelo método convencional (PCA) em amostras de leite pasteurizado tipos A, B, C e leite cru, obtidas no comércio de Piracicaba, antes e após a pasteurização em laboratório

\begin{tabular}{|c|c|c|c|c|c|c|}
\hline Amostras & Mesófilos & Mesof Past. & $\begin{array}{l}\text { Termófilos } \\
\text { (UFC/mL) }\end{array}$ & $\begin{array}{c}\text { Termof } \\
\text { Past. }\end{array}$ & Psicrotróficos & $\begin{array}{c}\text { Psicrot } \\
\text { Past. }\end{array}$ \\
\hline A I 1 & $2,2 \times 10^{3}$ & $2,3 \times 10^{2}$ & $1,0 \times 10^{1}$ & 0 & $1,9 \times 10^{2}$ & $1,1 \times 10^{1}$ \\
\hline A I 2 & $2,9 \times 10^{3}$ & $8,0 \times 10^{2}$ & 0 & 0 & $1,6 \times 10^{2}$ & $6,0 \times 10^{1}$ \\
\hline A I 3 & $1,6 \times 10^{6}$ & $1,8 \times 10^{3}$ & $1,6 \times 10^{2}$ & $8,5 \times 10^{2}$ & $8,3 \times 10^{2}$ & $2,6 \times 10^{1}$ \\
\hline A II 4 & $1,9 \times 10^{3}$ & $1,9 \times 10^{2}$ & $2,5 \times 10^{1}$ & $1,3 \times 10^{1}$ & $2,7 \times 10^{2}$ & 0 \\
\hline A II 5 & $1,0 \times 10^{3}$ & $1,0 \times 10^{2}$ & $1,0 \times 10^{1}$ & 5 & $1,2 \times 10^{2}$ & 0 \\
\hline A II 6 & $2,6 \times 10^{2}$ & $7,0 \times 10^{1}$ & $3,6 \times 10^{1}$ & $1,9 \times 10^{1}$ & $2,4 \times 10^{2}$ & 0 \\
\hline A III 7 & $3,6 \times 10^{2}$ & $3,5 \times 10^{1}$ & 0 & 0 & $2,0 \times 10^{2}$ & $1,5 \times 10^{1}$ \\
\hline A III 8 & $1,7 \times 10^{2}$ & $6,1 \times 10^{1}$ & $1,0 \times 10^{1}$ & 0 & $1,3 \times 10^{2}$ & 0 \\
\hline A III 9 & $1,7 \times 10^{2}$ & $2,4 \times 10^{1}$ & 0 & 0 & $1,9 \times 10^{1}$ & 0 \\
\hline média & $1,8 \times 10^{5}$ & $3,7 \times 10^{2}$ & $1,1 \times 10^{2}$ & $2,2 \times 10^{1}$ & $2,3 \times 10^{2}$ & $1,2 \times 10^{1}$ \\
\hline B I 1 & $1,1 \times 10^{4}$ & $4,5 \times 10^{3}$ & $1,5 \times 10^{1}$ & $\begin{array}{l}4 \\
0\end{array}$ & $1,6 \times 10^{2}$ & 0 \\
\hline B I 2 & $8,7 \times 10^{3}$ & $4,3 \times 10^{3}$ & 0 & 0 & $5,5 \times 10^{1}$ & 0 \\
\hline B I 3 & $1,6 \times 10^{4}$ & $1,5 \times 10^{3}$ & 0 & 0 & $7,4 \times 10^{2}$ & 0 \\
\hline B II 4 & $7,2 \times 10^{2}$ & $1,3 \times 10^{2}$ & 5 & 0 & $3,5 \times 10^{1}$ & 0 \\
\hline B II 5 & $95 \times 10^{2}$ & $7,5 \times 10^{1}$ & $1,0 \times 10^{1}$ & 5 & $6,0 \times 10^{1}$ & 0 \\
\hline B II 6 & $9,1 \times 10^{2}$ & $1,0 \times 10^{2}$ & $1,5 \times 10^{1}$ & $1,0 \times 10^{1}$ & $1,2 \times 10^{2}$ & 0 \\
\hline B III 7 & $1,4 \times 10^{3}$ & $4,5 \times 10^{1}$ & $1,2 \times 10^{1}$ & 0 & $3,5 \times 10^{1}$ & 0 \\
\hline B III 8 & $1,4 \times 10^{3}$ & $6,5 \times 10^{1}$ & $1,5 \times 10^{1}$ & 0 & $1,2 \times 10^{1}$ & 5 \\
\hline B III 9 & $1,3 \times 10^{3}$ & $2,5 \times 10^{1}$ & $1,0 \times 10^{1}$ & 0 & $6,0 \times 10^{1}$ & 0 \\
\hline média & $4,7 \times 10^{3}$ & $1,2 \times 10^{3}$ & 9,1 & 1,7 & $1,4 \times 10^{2}$ & 0,5 \\
\hline C I 1 & $3,0 \times 10^{3}$ & $8,3 \times 10^{2}$ & 0 & 0 & $2,1 \times 10^{3}$ & $1,6 \times 10^{2}$ \\
\hline C I 2 & $6,0 \times 10^{3}$ & $4,0 \times 10^{2}$ & $1,5 \times 10^{1}$ & 0 & $4,5 \times 10^{3}$ & $1,0 \times 10^{2}$ \\
\hline C I 3 & $8,7 \times 10^{3}$ & $6,1 \times 10^{2}$ & $1,0 \times 10^{1}$ & 0 & $1,1 \times 10^{3}$ & $1,3 \times 10^{2}$ \\
\hline C II 4 & $2,5 \times 10^{4}$ & $2,5 \times 10^{3}$ & $4,5 \times 10^{1}$ & $2,5 \times 10^{1}$ & $7,5 \times 10^{2}$ & $6,5 \times 10^{1}$ \\
\hline C II 5 & $1,3 \times 10^{4}$ & $1,8 \times 10^{3}$ & $1,0 \times 10^{1}$ & 0 & $5,5 \times 10^{3}$ & $9,0 \times 10^{1}$ \\
\hline C II 6 & $2,0 \times 10^{4}$ & $3,0 \times 10^{3}$ & $2,0 \times 10^{1}$ & $1,0 \times 10^{1}$ & $8,0 \times 10^{2}$ & $4,5 \times 10^{1}$ \\
\hline C III 7 & $4,0 \times 10^{2}$ & $3,5 \times 10^{1}$ & $1,3 \times 10^{2}$ & $7,0 \times 10^{1}$ & $1,1 \times 10^{2}$ & $1,0 \times 10^{1}$ \\
\hline C III 8 & $6,4 \times 10^{2}$ & $1,0 \times 10^{1}$ & $5,5 \times 10^{1}$ & $3,0 \times 10^{1}$ & $7,0 \times 10^{1}$ & 5 \\
\hline C III 9 & $7,6 \times 10^{2}$ & $1,5 \times 10^{1}$ & $6,5 \times 10^{1}$ & $3,5 \times 10^{1}$ & $4,5 \times 10^{1}$ & 3 \\
\hline média & $8,6 \times 10^{3}$ & $1,0 \times 10^{3}$ & $3,9 \times 10^{1}$ & $1,9 \times 10^{1}$ & $1,6 \times 10^{3}$ & $6,8 \times 10^{1}$ \\
\hline Cru 1 & $5,8 \times 10^{7}$ & $7,1 \times 10^{2}$ & $1,5 \times 10^{1}$ & $1,0 \times 10^{1}$ & $1,1 \times 10^{2}$ & 0 \\
\hline Cru 2 & $9,1 \times 10^{7}$ & $8,0 \times 10^{2}$ & 5 & 5 & $6,5 \times 10^{3}$ & 0 \\
\hline Cru 3 & $2,5 \times 10^{6}$ & $3,3 \times 10^{3}$ & $4,0 \times 10^{1}$ & $3,0 \times 10^{1}$ & $8,5 \times 10^{3}$ & 5 \\
\hline média & $5,1 \times 10^{7}$ & $1,6 \times 10^{3}$ & $2,0 \times 10^{1}$ & $1,5 \times 10^{1}$ & $5,0 \times 10^{3}$ & 1,7 \\
\hline
\end{tabular}

A-B-C-Cru: tipos de leite

I-II-III: marca

Números: número de amostras 


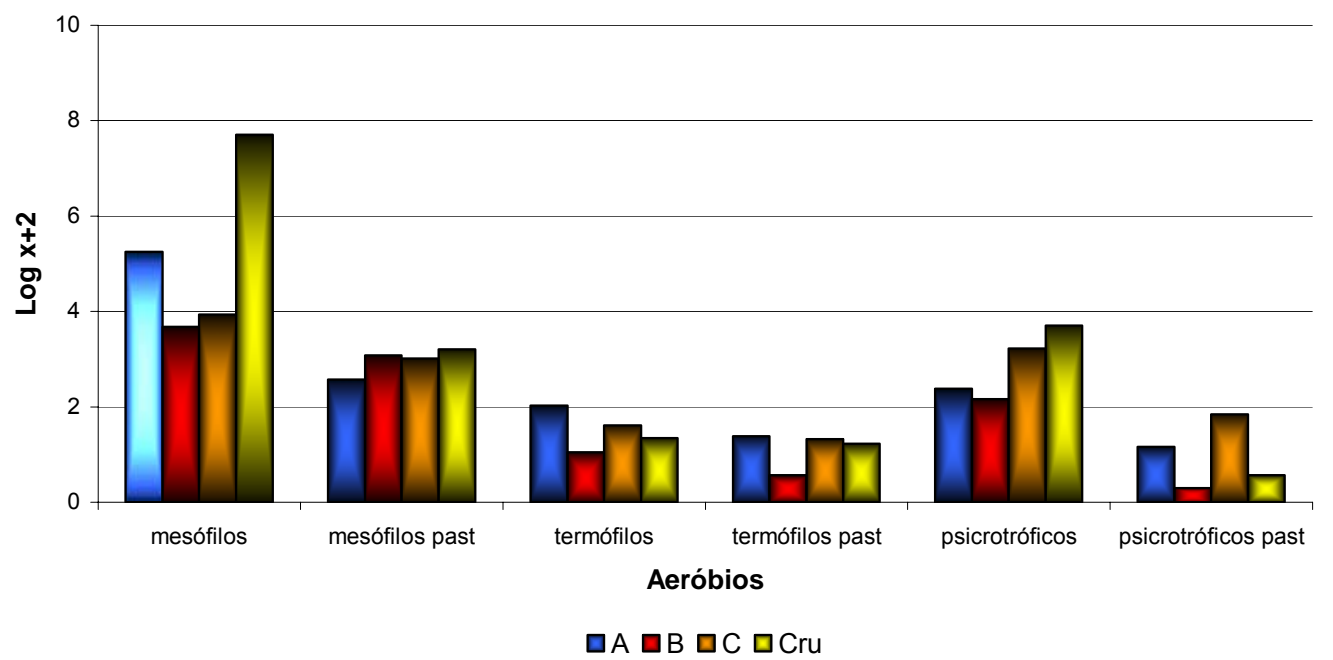

Figura 11 - Médias das contagens de mesófilos, termófilos e psicrotróficos, antes e após a pasteurização (past) em laboratório

\subsubsection{Aeróbios mesófilos}

Nas amostras de leite do tipo A, as contagens de mesófilos (Tabela 4) variaram de $1,7 \times 10^{2}$ a $1,6 \times 10^{6} \mathrm{UFC} / \mathrm{mL}$, sendo que $4(44,4 \%)$ amostras apresentaram valores acima dos tolerados pelo Departamento de Inspeção de Produtos de Origem Animal - DIPOA (Brasil, 2002) e 5 (55,6\%) amostras acima dos padrões mencionados pelo RIISPOA (Brasil, 1980).

Nas amostras de leite tipo $B$ os valores encontrados nas contagens de mesófilos variaram de 7,2 × $10^{2}$ a $1,6 \times 10^{4} \mathrm{UFC} / \mathrm{mL}$, portanto, nenhuma amostra analisada apresentou contagens acima das toleradas pelos padrões do RIISPOA (Brasil, 1980) e do DIPOA (Brasil, 2002).

Nas amostras de leite tipo C, as contagens de mesófilos variaram de 4,0 × $10^{2}$ a $2,5 \times 10^{4} \mathrm{UFC} / \mathrm{mL}$, portanto, também nenhuma amostra apresentou irregularidade em relação aos padrões citados anteriormente.

No caso da amostra AII5, em relação à contagem de microrganismos mesófilos, vale destacar que a legislação DIPOA (Brasil, 2002) é menos exigente em 
relação a que estava em vigência em 1980. Esta amostra não seria aprovada como foi pela legislação em vigor.

Após a nova pasteurização no laboratório das amostras de leite tipos A, B e C, somente uma amostra $(11,1 \%)$ de leite tipo A apresentou valor acima do permitido pela legislação, já que esta se encontrava muito contaminada quando foi obtida no comércio $\left(1,6 \times 10^{6} \mathrm{UFC} / \mathrm{mL}\right)$.

As 3 amostras de leite cru analisadas apresentaram contagens de mesófilos entre $2,5 \times 10^{6}$ e 9,1 x $10^{7} \mathrm{UFC} / \mathrm{mL}$. Pelos valores citados na Tabela 1 , tais amostras não estariam satisfazendo as exigências para contagem de mesófilos em leite tipos A e B, antes da pasteurização. No entanto, após a pasteurização $\left(62,8^{\circ} \mathrm{C} / 30^{\prime}\right)$ no laboratório, 2 $(66,7 \%)$ atenderiam aos padrões DIPOA (Brasil, 2002) para leite pasteurizado tipo A e 1 $(33,3 \%)$ atenderia aos padrões do mesmo órgão para leite pasteurizado tipo B. Se a comparação fosse feita com os padrões RIISPOA (Brasil, 1980), as 3 amostras de leite cru, após a pasteurização no laboratório, atenderiam as especificações para leite pasteurizado tipo B.

No trabalho de Tavares (1996) os valores encontrados em 24 amostras de leite pasteurizado tipo A analisadas variaram de $8,5 \times 10^{1}$ a $3,7 \times 10^{5} \mathrm{UFC}$ de mesófilos $/ \mathrm{mL}$. Em 36 amostras de leite pasteurizado tipo B os valores variaram de $1,8 \times 10^{4}$ a $5,2 \mathrm{x}$ $10^{6}$ UFC de mesófilos/mL e em 48 amostras de leite pasteurizado tipo $\mathrm{C}$ os valores tiveram variação de 5,2 x $10^{3}$ a $1,6 \times 10^{7} \mathrm{UFC}$ de mesófilos $/ \mathrm{mL}$.

Nader Filho et al. (1997) observaram que de 28 amostras de leite pasteurizado tipo A integral analisadas, $3(10,7 \%)$ tiveram valores de mesófilos acima dos permitidos pela legislação.

$\mathrm{Na}$ presente pesquisa, os percentuais de amostras em desacordo com os padrões estabelecidos para a contagem de mesófilos em leite pasteurizado tipo A, superaram os valores encontrados por Santos et al. (1999).

Os valores das contagens de mesófilos, realizadas por Freitas et al. (2002), foram de $1,0 \times 10^{1}$ a $2,3 \times 10^{7} \mathrm{UFC} / \mathrm{mL}$ em 13 amostras de leite pasteurizado tipo A integral, $1,0 \times 10^{1}$ a 2,5 x $10^{7} \mathrm{UFC} / \mathrm{mL}$ em 13 amostras de leite pasteurizado desnatado, $1,0 \times 10^{1}$ a incontáveis em 31 amostras de leite pasteurizado tipo C, 9,2 × $10^{5}$ a 
incontáveis em 12 amostras de leite cru.

Nader Filho (1996) ao avaliar características microbiológicas das amostras de leite pasteurizado tipo B, colhidas logo após o envase, em algumas usinas de beneficiamento do Estado de São Paulo, subordinadas ao Serviço de Inspeção Federal (SIF), observaram que $65 \%$ das amostras analisadas apresentavam-se fora dos padrões legais.

Os percentuais de amostras acima dos padrões para a contagem de mesófilos no leite tipo B, foram inferiores aos valores encontrados por Santos et al. (1999) e Polegato (1999).

Wendpap \& Rosa (1997) observaram que de 50 amostras de leite pasteurizado tipo C, 8 (16\%) estavam em desacordo com os padrões microbiológicos. Comparando estes resultados à pesquisa de Wendpap \& Rosa (1995), observa-se que houve queda da qualidade microbiológica deste produto, visto que na ocasião 3\% das unidades amostrais apresentavam contagens microbiológicas acima dos padrões.

No trabalho de Leite et al. (2002) as contagens de bactérias aeróbias mesófilas variaram entre $1,4 \times 10^{2}$ a $2,2 \times 10^{6} \mathrm{UFC} / \mathrm{mL}$, das quais, apenas uma amostra encontrava-se fora do valor limite aceitável para padrão de leite tipo C.

$\mathrm{Na}$ presente pesquisa, os percentuais de amostras em desacordo com os padrões estabelecidos para a contagem de mesófilos em leite pasteurizado tipo C foram inferiores aos valores encontrados por Wendpap \& Rosa (1995), Wendpap \& Rosa (1997), Gonçalves \& Franco (1998), Hoffman et al. (1999), Padilha \& Fernandes (1999), Polegato (1999), Santos et al. (1999), Leite Jr \& Torrano (2000) e Freitas et al. (2002). A média percentual encontrada por esses autores foi $39 \%$ de amostras de leite tipo C acima dos limites impostos pela legislação.

Na pesquisa realizada por Vieira et al. (1995), foram encontradas contagens de mesófilos acima de $6,8 \times 10^{6} \mathrm{UFC} / \mathrm{mL}$ em 8 amostras de leite cru.

Santos \& Bergmann (2003) estudando amostras de leite cru transportadas em temperatura ambiente, observaram que 57,6\% apresentaram contagens de 7,0 x 106 , enquanto Chung et al. (1984) observaram que em 56,4\% das amostras que foram deixadas por 3 horas à temperatura ambiente, antes da realização da análise, as 
contagens estiveram acima de $4,0 \times 10^{6} \mathrm{UFC} / \mathrm{mL}$.

Villar et al. (1996) encontraram contagens de mesófilos $(\log \mathrm{UFC} / \mathrm{mL})$ variando de 4,26 a 5,61 com média de 4,88. Também as contagens encontradas por Mutukumira et al. (1996) em 10 amostras de leite cru mantido à temperatura de $4^{\circ} \mathrm{C}$, variaram de $6,2 \times 10^{3}$ a 7,8 x $10^{7} \mathrm{UFC} / \mathrm{mL}$. Em 98,4\% das amostras encontraram-se valores acima de $1,0 \times 10^{5} \mathrm{UFC} / \mathrm{mL}$. No trabalho de Barros et al. (1999), 87\% das amostras mantidas sob a refrigeração tiveram valores de mesófilos dentro dos padrões exigidos pela legislação.

Os valores encontrados no presente trabalho para as contagens de mesófilos no leite cru, foram parecidos aos valores encontrados por Freitas et al. (2002).

Hoje, tanto os padrões da ANVISA (Brasil, 2001) como os do DIPOA (Brasil, 2002), não mencionam parâmetros microbiológicos para leite cru.

Nota-se uma certa coerência entre os \% de amostras de leite pasteurizado tipo A analisadas na presente pesquisa para mesófilos aeróbios e que se mostraram fora dos padrões DIPOA (Brasil, 2002) com os resultados mencionados pelos trabalhos citados. Em relação às amostras de leite pasteurizado tipos $\mathrm{B}$ e $\mathrm{C}$, analisadas no presente trabalho, se apresentaram em melhores condições microbiológicas para as contagens de mesófilos aeróbios, uma vez que $100 \%$ delas estiveram em conformidade com os padrões DIPOA (Brasil, 2002).

\subsubsection{Aeróbios psicrotróficos}

Atualmente não existe uma legislação referente a contagens de psicrotróficos para leite, portanto, não existem muitos trabalhos enfocando esse grupo de microrganismos.

No presente trabalho as contagens de psicrotróficos, considerando todas as amostras analisadas (leite A, B, C e cru) variaram de $1,2 \times 10^{1}$ a $8,5 \times 10^{3} \mathrm{UFC}$ de psicrotróficos $/ \mathrm{mL}$.

Segundo Sorhaung \& Stepaniak (1997) as alterações organolépticas e estruturais de queijos, causadas por enzimas proteolíticas de psicrotróficos foram 
encontradas quando as contagens desses microrganismos no leite estavam entre 2,0 x $10^{6}$ a 2,0 x $10^{8} \mathrm{UFC} / \mathrm{mL}$. Pode se inferir que todas as amostras de leite analisadas neste trabalho não deveriam ter alterações organolépticas devido a microrganismos psicrotróficos, pois as contagens estiveram muito abaixo das mencionadas no trabalho citado.

Na pesquisa de Tavares (1996) os valores encontrados em 24 amostras de leite pasteurizado tipo A variaram de $1,1 \times 10^{2}$ a $5,9 \times 10^{3} \mathrm{UFC}$ de psicrotróficos $/ \mathrm{mL}$. Em 36 amostras de leite pasteurizado tipo $B$ os valores variaram de $1,2 \times 10^{2}$ a 4,6 x $10^{4}$ UFC de psicrotróficos $/ \mathrm{mL}$ e em 48 amostras de leite pasteurizado tipo $\mathrm{C}$ os valores tiveram variação de $1,2 \times 10^{2}$ a $3,4 \times 10^{5} \mathrm{UFC}$ de psicrotróficos $/ \mathrm{mL}$. Tais contagens, de uma forma geral, estiveram bem acima das encontradas na presente pesquisa.

Os psicrotróficos termodúricos constituem um importante grupo de microrganismos que, além de multiplicarem-se bem a temperatura de refrigeração, podem sobreviver à temperatura de pasteurização. Estes são classificados como Grampositivos formadores ou não de esporos, pertencentes principalmente ao gênero Bacillus (Muir, 1996; Santos ,1999; Sorhaung \& Stepaniak, 1997).

Normalmente, as enzimas proteolíticas (termoestáveis) produzidas por psicrotróficos promovem quebra de proteínas, provocando alterações físicas e organolépticas que comprometem o consumo e a produção de derivados do leite (Santos, 1999; Shah,1994).

\subsubsection{Aeróbios termófilos}

Assim como para os microrganismos psicrotróficos, não existe uma legislação referente a contagens de microrganismos termófilos para leite, portanto, não existem muitos trabalhos enfocando esse grupo de microrganismos.

No presente trabalho, as contagens de termófilos variaram de $<10$ a $1,6 \times 10^{2}$ UFC/mL. Não foi encontrada nenhuma referência bibliográfica atual a respeito de termófilos em leite, talvez por não haver legislação recente que estipule a tolerância desse grupo de microrganismos nesse substrato. 
No trabalho de Tavares (1996) os valores encontrados em 24 amostras de leite pasteurizado tipo A variaram de $2,0 \times 10^{1}$ a $3,8 \times 10^{3} \mathrm{UFC}$ de termófilos $/ \mathrm{mL}$. Em 36 amostras de leite pasteurizado tipo B os valores variaram de $2,5 \times 10^{1}$ a $1,5 \times 10^{4}$ UFC de termófilos $/ \mathrm{mL}$ e em 48 amostras de leite pasteurizado tipo $\mathrm{C}$ os valores tiveram variação de 5,0 × $10^{1}$ a 2,3 $\times 10^{5} \mathrm{UFC}$ de termófilos $/ \mathrm{mL}$. Aqui também as contagens de termófilos foram superiores às encontradas na presente pesquisa para o mesmo grupo de microrganismos.

Nota-se que o maior valor encontrado na presente pesquisa em relação aos microrganismos termófilos foi em uma amostra de leite tipo A enquanto no trabalho de Tavares (1996) foi em leite tipo C.

É importante salientar que a legislação deveria também se preocupar com outros tipos de bactérias que possam causar alterações organolépticas e conseqüentemente perda nutricional do leite, como por exemplo, psicrotróficos e termófilos.

\subsection{NMP de coliformes totais}

$\mathrm{Na}$ Tabela 5, estão representados os NMP de coliformes totais presentes nos leites de diferentes marcas dos tipos A, B, C e cru, analisadas pelo método convencional (tubos múltiplos) e SimPlate ${ }^{\circledR}$. Também foi feita a média dos valores para os tipos de leite analisados (Figura 12) para melhor visualização dos dados. 
Tabela 5. Número Mais Provável (NMP) de coliformes totais pelo método convencional (tubos múltiplos) e Simplate ${ }^{\circledR}$, obtido em amostras de diferentes tipos de leite coletados no comércio de Piracicaba antes e após pasteurização em laboratório

\begin{tabular}{|c|c|c|c|c|}
\hline Amostras & $\begin{array}{l}\text { Tubos Múltiplos } \\
\text { (NMP/mL) }\end{array}$ & $\begin{array}{l}\text { Tubos Múltiplos } \\
\text { Past. (NMP/mL) }\end{array}$ & $\begin{array}{c}\text { SimPlate } \\
(\mathrm{NMP} / \mathrm{mL})\end{array}$ & $\begin{array}{c}\text { SimPlate } \\
\text { Past.(NMP/mL) }\end{array}$ \\
\hline A I 1 & $<2$ & $<2$ & $<2$ & $<2$ \\
\hline A I 2 & 2 & $<2$ & 6 & $<2$ \\
\hline A I 3 & $2,1 \times 10^{1}$ & 2 & $7,3 \times 10^{1}$ & $<2$ \\
\hline A II 4 & 6 & $<2$ & 8 & $<2$ \\
\hline A II 5 & 4 & $<2$ & 4 & $<2$ \\
\hline A II 6 & 2 & $<2$ & 2 & $<2$ \\
\hline A III 7 & 4 & $<2$ & 4 & $<2$ \\
\hline A III 8 & $<2$ & $<2$ & $<2$ & $<2$ \\
\hline A III 9 & $<2$ & $<2$ & $<2$ & $<2$ \\
\hline média & 4,3 & 0,2 & $1,1 \times 10^{1}$ & 0 \\
\hline B I 1 & $2,1 \times 10^{1}$ & $<2$ & $3,2 \times 10^{1}$ & $<2$ \\
\hline B I 2 & 7 & $<2$ & $1,2 \times 10^{1}$ & $<2$ \\
\hline B I 3 & $7,9 \times 10^{1}$ & $<2$ & $9,6 \times 10^{1}$ & $<2$ \\
\hline B II 4 & $<2$ & $<2$ & $<2$ & $<2$ \\
\hline B II 5 & $<2$ & $<2$ & $<2$ & $<2$ \\
\hline B II 6 & $<2$ & $<2$ & $<2$ & $<2$ \\
\hline B III 7 & $<2$ & $<2$ & $<2$ & $<2$ \\
\hline B III 8 & 2 & $<2$ & 2 & $<2$ \\
\hline B III 9 & $<2$ & $<2$ & $<2$ & $<2$ \\
\hline média & $1,2 \times 10^{1}$ & 0 & $1,6 \times 10^{1}$ & 0 \\
\hline C I 1 & $<2$ & $<2$ & $<2$ & $<2$ \\
\hline C I 2 & $<2$ & $<2$ & $<2$ & $<2$ \\
\hline C I 3 & $<2$ & $<2$ & $<2$ & $<2$ \\
\hline C II 4 & 2 & $<2$ & 2 & $<2$ \\
\hline C II 5 & $<2$ & $<2$ & $<2$ & $<2$ \\
\hline C II 6 & $<2$ & $<2$ & $<2$ & $<2$ \\
\hline C III 7 & $<2$ & $<2$ & $<2$ & $<2$ \\
\hline C III 8 & $<2$ & $<2$ & $<2$ & $<2$ \\
\hline C III 9 & $<2$ & $<2$ & $<2$ & $<2$ \\
\hline Média & 0,2 & 0 & 0,2 & 0 \\
\hline Cru 1 & $1,1 \times 10^{2}$ & $<2$ & $2,6 \times 10^{1}$ & $<2$ \\
\hline Cru 2 & $4,9 \times 10^{1}$ & $<2$ & $2,2 \times 10^{1}$ & $<2$ \\
\hline Cru 3 & $1,6 \times 10^{3}$ & $<2$ & $7,4 \times 10^{2}$ & $<2$ \\
\hline média & $5,9 \times 10^{2}$ & 0 & $2,6 \times 10^{2}$ & 0 \\
\hline
\end{tabular}

A-B-C-Cru: tipos de leite I-II-III: marca

Números: número de amostras 


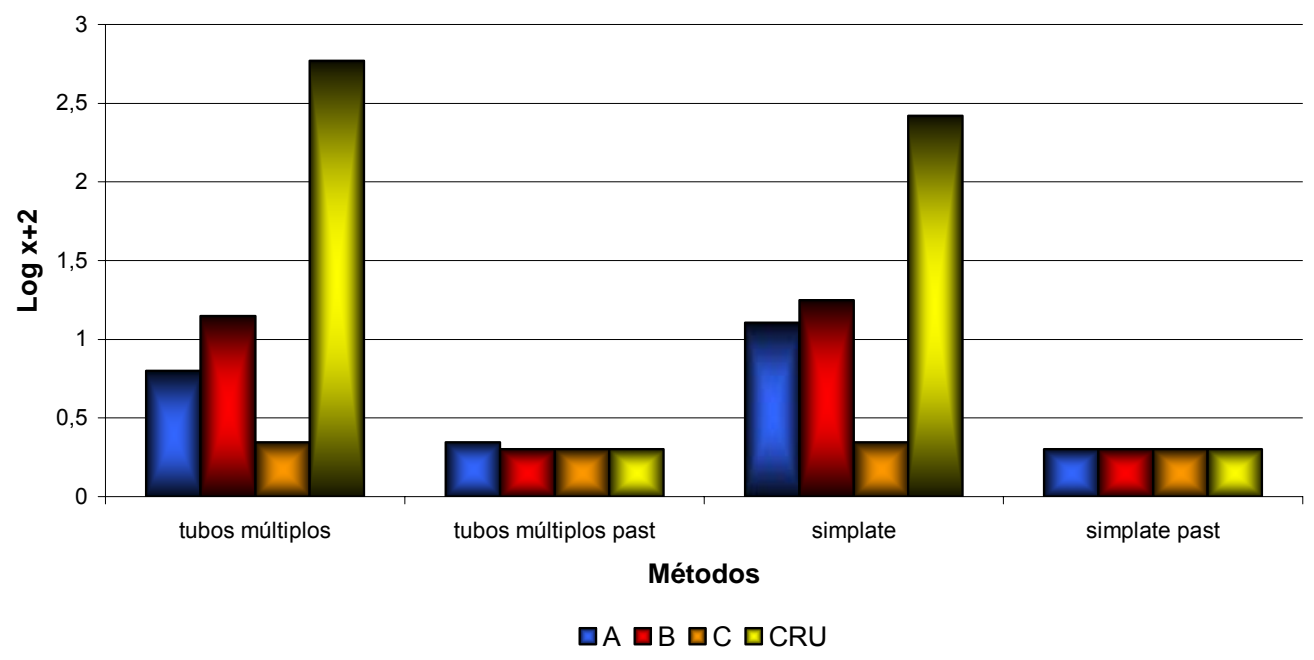

Figura 12 - Médias do NMP de coliformes totais encontradas para as amostras de leite pasteurizado tipos A, B, C e leite cru analisadas antes da pasteurização no laboratório e após a mesma

Vale lembrar que a menção $<2 \mathrm{NMP} / \mathrm{mL}$ diz respeito à ausência de tubos positivos, ou seja, nenhum dos tubos inoculados mostrou fermentação da lactose com produção de gás. Assim, para o cálculo das médias e para a análise estatística dos dados, a fim de estabelecer comparação entre os métodos NMP (tubos múltiplos) e Simplate ${ }^{\circledR}$, tais valores foram considerados como zero, ou ausência de coliformes $/ \mathrm{mL}$ de leite.

Segundo a Instrução Normativa $\mathrm{n}^{\mathrm{0}} 51$, do Departamento de Inspeção de Produtos de Origem Animal - DIPOA (Brasil, 2002), a tolerância para coliformes totais no leite pasteurizado tipos A, B e C é $<1,5$ e $4 \mathrm{NMP} / \mathrm{mL}$, respectivamente. Atualmente a RDC nº12 - ANVISA (Brasil, 2001) somente refere-se à tolerância de até 4 NMP de coliformes a $45^{\circ} \mathrm{C} / \mathrm{mL}$ de leite pasteurizado. 


\subsubsection{Análise de coliformes totais por tubos múltiplos}

As amostras de leite pasteurizado tipos A, B e C e do leite cru apresentaram valores variando de $<2$ a $2,1 \times 10^{1} ;<2$ a $7,9 \times 10^{1} ;<2$ a 2 e $4,9 \times 10^{1}$ a $1,6 \times 10^{3}$ NMP de coliformes totais/mL, respectivamente. Em relação ao leite tipo A, $6(66,7 \%)$ amostras estiveram fora dos padrões exigidos pelo Departamento de Inspeção de Produtos de Origem Animal - DIPOA (Brasil, 2002). Para o leite tipos B e C, 3 (33,3\%) amostras e $0(0,0 \%)$ amostras, respectivamente, estiveram fora dos padrões exigidos pelo DIPOA. As 3 amostras de leite cru apresentaram valores elevados, mas vale salientar que não existem parâmetros microbiológicos para o mesmo. Os valores encontrados como NMP de coliformes totais $/ \mathrm{mL}$ de leite cru foram muito superiores aos encontrados para as amostras de leite pasteurizado, reforçando a importância da pasteurização do leite. Enfatizando a importância da pasteurização do leite, basta verificar que tal processo realizado no laboratório levou as amostras adquiridas de leite cru, a apresentarem ausência de coliformes após o tratamento térmico.

Ao pasteurizar todas as amostras no laboratório, os valores diminuíram drasticamente, permanecendo acima do padrão apenas uma amostra de leite tipo A e, mesmo assim, com apenas $2 \mathrm{NMP} / \mathrm{mL}$. Devido a tal constatação, algumas hipóteses podem ser levantadas em relação as amostras de leite pasteurizado adquiridas para a presente pesquisa: matéria-prima excessivamente contaminada, pasteurização industrial não adequada, condições de transporte, distribuição, armazenamento e comercialização do leite nos pontos de venda inadequadas, o que teria permitido sobrevivência e multiplicação bacteriana.

\subsubsection{Análise de coliformes totais pelo método SimPlate ${ }^{\circledR}$}

Pelo método SimPlate ${ }^{\circledR}$, as amostras de leite pasteurizado tipos A, B e C e o leite cru apresentaram contagens variando de $<2$ a $7,3 \times 10^{1} ;<2$ a 9,6 $\times 10^{1} ;<2$ a 2 e 2,2 x $10^{1}$ a $7,3 \times 10^{2} \mathrm{NMP}$ de coliformes totais $/ \mathrm{mL}$, respectivamente. Em relação ao leite tipo A, $6(66,7 \%)$ amostras estiveram acima dos padrões exigidos pelo Departamento de 
Inspeção de Produtos de Origem Animal (DIPOA). Para o leite tipos B e C, 3 (33,3\%) e $0(0,0 \%)$ amostras, respectivamente, estiveram acima dos padrões exigidos pelo DIPOA. Nota-se que os mesmos percentuais de amostras consideradas fora dos padrões do DIPOA (Brasil, 2002) para coliformes totais, quando se utilizou a metodologia SimPlate ${ }^{\circledR}$, foram encontrados para as mesmas amostras analisadas para coliformes totais quando a metodologia utilizada foi a de tubos múltiplos. As 3 amostras do leite cru também apresentaram valores elevados, embora os padrões para esse tipo de leite não sejam mencionados pelos parâmetros citados no presente trabalho. As contagens de coliformes totais/mL de leite cru foram superiores aos encontrados para as amostras de leite pasteurizado, o que mostra a eficácia da pasteurização na destruição bacteriana.

Após a pasteurização de todas as amostras de leite no laboratório, os valores não estiveram acima do padrão em nenhuma amostra analisada pelo sistema SimPlate ${ }^{\circledR}$.

O número de amostras fora dos padrões na contagem de coliformes totais no leite tipo A e no leite tipo B superaram os valores encontrados por Wendpap \& Rosa (1995), Santos et al. (1999), Leite Jr \& Torrano (2000). Os valores encontrados por esses pesquisadores variaram de 5 a 5,9 x $10^{1} \mathrm{NMP}$ coliformes totais $/ \mathrm{mL}$.

Na pesquisa de Freitas et al. (2002), das 37 amostras de leite pasteurizado desnatado tipo B analisadas, 10 (27\%) excederam o padrão microbiológico para coliformes totais. Em relação ao leite pasteurizado tipo C, de 51 amostras analisadas, 10 $(19,6 \%)$ excederam o limite para coliformes totais e as amostras de leite cru analisadas apresentaram valores entre 5,1 x 10 e 7,9 x 10² NMP de coliformes totais $/ \mathrm{mL}$.

$\mathrm{O}$ número de amostras fora dos padrões na contagem de coliformes totais no leite pasteurizado tipo $\mathrm{C}$, encontrado no presente trabalho, foi inferior aos encontrados por Wendpap \& Rosa (1995), Nader Filho (1996), Wendpap \& Rosa (1997), Gonçalves \& Franco (1998), Padilha \& Fernandes (1999), Santos et al. (1999), Leite Jr \& Torrano (2000) e Freitas et al. (2002). Os valores encontrados por esses pesquisadores variaram de 8 a $1,7 \times 10^{2} \mathrm{NMP} / \mathrm{mL}$.

No trabalho de Tavares (1996) os valores encontrados em 24 amostras de leite pasteurizado tipo A variaram de 0,36 a $29 \mathrm{NMP}$ de coliformes totais $/ \mathrm{mL}$. Em 36 amostras de leite pasteurizado tipo $\mathrm{B}$ os valores variaram de 0,91 a >110 NMP de 
coliformes totais/mL e em 48 amostras de leite pasteurizado tipo $\mathrm{C}$ os valores tiveram variação de 0,36 a >110 NMP de coliformes totais/mL sendo, portanto, de uma forma geral, superiores aos encontrados na presente pesquisa.

Os valores de NMP para coliformes totais, no leite cru, encontrados na presente pesquisa foram superiores aos valores citados por Freitas et al. (2002), valendo ressaltar que no presente trabalho foram utilizadas menos amostras.

Vieira et al. (1995), encontraram em relação a coliformes totais valores entre $4,5 \times 10^{1}$ e $1,2 \times 10^{3} \mathrm{NMP} / \mathrm{mL}$ em 8 amostras de leite cru. Tanto os padrões do DIPOA (Brasil, 2002) e da ANVISA (Brasil, 2001) não citam parâmetros para leite cru.

\subsection{Número Mais Provável (NMP) de coliformes fecais}

$\mathrm{Na}$ Tabela 6, são apresentados os NMP de coliformes fecais $\left(45^{\circ} \mathrm{C}\right)$ encontrados nas amostras de leites pasteurizados de diferentes marcas dos tipos A, B, C e leite cru, analisadas pelo método convencional (tubos múltiplos) e de E. coli pelo método SimPlate ${ }^{\circledR}$. Nesta Tabela, o valor $<2$ foi considerado zero, tanto para o cálculo das médias, como para a análise estatística, a fim de se estabelecer comparação entre os métodos NMP (tubos múltiplos) e SimPlate ${ }^{\circledR}$. Também foi feita a média dos valores para os tipos de leite analisados (Figura 13) para melhor visualização dos dados. 
Tabela 6. Número Mais Provável (NMP) de coliformes à $45^{\circ} \mathrm{C}$ pelo método convencional (tubos múltiplos) e E. coli pelo Simplate ${ }^{\circledR}$ encontrado em amostras de leite obtidas no comércio de Piracicaba antes e após pasteurização em laboratório

\begin{tabular}{|c|c|c|c|c|}
\hline Amostras & $\begin{array}{c}\text { Tubos } \\
\text { Múltiplos } \\
\text { (NMP/mL) }\end{array}$ & $\begin{array}{l}\text { Tubos Múltiplos } \\
\text { Past. (NMP/mL) }\end{array}$ & $\begin{array}{c}\text { SimPlate } \\
(\mathrm{NMP} / \mathrm{mL})\end{array}$ & $\begin{array}{c}\text { SimPlate } \\
\text { Past.(NMP/mL) }\end{array}$ \\
\hline A I 1 & $<2$ & $<2$ & $<2$ & $<2$ \\
\hline A I 2 & 2 & $<2$ & $<2$ & $<2$ \\
\hline A I 3 & $2,8 \times 10^{1}$ & $<2$ & $2,1 \times 10^{1}$ & $<2$ \\
\hline A II 4 & 4 & $<2$ & 2 & $<2$ \\
\hline A II 5 & 4 & $<2$ & 2 & $<2$ \\
\hline A II 6 & 4 & $<2$ & 2 & $<2$ \\
\hline A III 7 & $<2$ & $<2$ & $<2$ & $<2$ \\
\hline A III 8 & $<2$ & $<2$ & $<2$ & $<2$ \\
\hline A III 9 & $<2$ & $<2$ & $<2$ & $<2$ \\
\hline média & 4,7 & 0 & 3 & 0 \\
\hline B I 1 & $1,4 \times 10^{1}$ & $<2$ & $1,0 \times 10^{1}$ & $<2$ \\
\hline B I 2 & 6 & $<2$ & 4 & $<2$ \\
\hline B I 3 & $2,4 \times 10^{1}$ & $<2$ & $1,7 \times 10^{1}$ & $<2$ \\
\hline B II 4 & $<2$ & $<2$ & $<2$ & $<2$ \\
\hline B II 5 & $<2$ & $<2$ & $<2$ & $<2$ \\
\hline B II 6 & $<2$ & $<2$ & $<2$ & $<2$ \\
\hline B III 7 & $<2$ & $<2$ & $<2$ & $<2$ \\
\hline B III 8 & $<2$ & $<2$ & $<2$ & $<2$ \\
\hline B III 9 & $<2$ & $<2$ & $<2$ & $<2$ \\
\hline média & 4,9 & 0 & 3,4 & 0 \\
\hline C I 1 & $<2$ & $<2$ & $<2$ & $<2$ \\
\hline C I 2 & $<2$ & $<2$ & $<2$ & $<2$ \\
\hline C I 3 & $<2$ & $<2$ & $<2$ & $<2$ \\
\hline C II 4 & 2 & $<2$ & 2 & $<2$ \\
\hline C II 5 & $<2$ & $<2$ & $<2$ & $<2$ \\
\hline C II 6 & $<2$ & $<2$ & $<2$ & $<2$ \\
\hline C III 7 & $<2$ & $<2$ & $<2$ & $<2$ \\
\hline C III 8 & $<2$ & $<2$ & $<2$ & $<2$ \\
\hline C III 9 & $<2$ & $<2$ & $<2$ & $<2$ \\
\hline média & 0,2 & 0 & 0,2 & 0 \\
\hline Cru 1 & $4,6 \times 10^{1}$ & $<2$ & $1,2 \times 10^{1}$ & $<2$ \\
\hline Cru 2 & $2,2 \times 10^{1}$ & $<2$ & 8 & $<2$ \\
\hline Cru 3 & $9,2 \times 10^{2}$ & $<2$ & $3,7 \times 10^{2}$ & $<2$ \\
\hline média & $3,3 \times 10^{2}$ & 0 & $1,3 \times 10^{2}$ & 0 \\
\hline
\end{tabular}

A-B-C-Cru: tipos de leite

I-II-III: marca

Números: número de amostras 


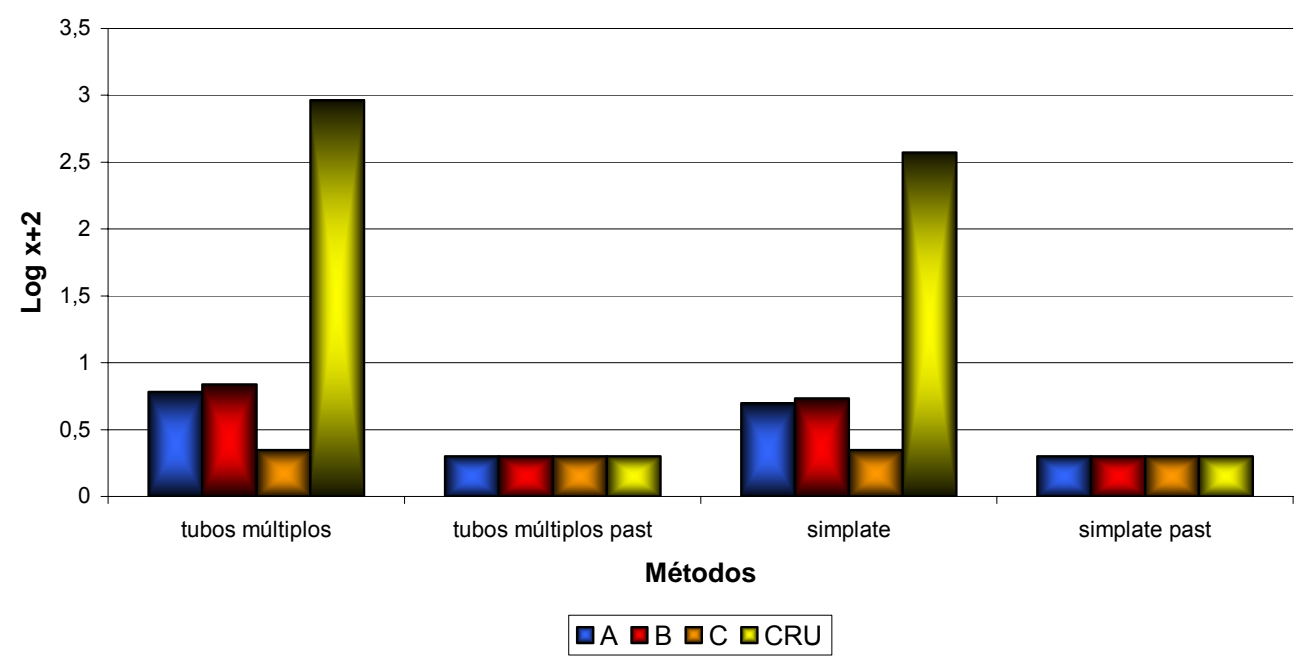

Figura 13 - Médias do NMP de coliformes fecais $\left(45^{\circ} \mathrm{C}\right)$ obtidas pela técnica dos tubos múltiplos e de E. coli pelo método SimPlate ${ }^{\circledR}$, encontradas para as amostras de leite tipos A, B, C e leite cru analisadas antes da pasteurização no laboratório e após a mesma

\subsubsection{Análise de coliformes fecais por tubos múltiplos}

As amostras de leite pasteurizado tipo A analisadas no presente trabalho apresentaram valores de coliformes fecais variando de $<2$ a $2,8 \times 10^{1} \mathrm{NMP} / \mathrm{mL}$. Tanto para o Departamento de Inspeção de Produtos de Origem Animal - DIPOA (Brasil, 2002), quanto para o RIISPOA (Brasil, 1980), 5 (55,6\%) amostras estariam acima do padrão estabelecido para coliformes fecais. Para a ANVISA (Brasil, 2001), 4 amostras (14,8\%) (1 do leite tipo A e 3 do tipo B) estariam com valores acima do tolerado, já que esta legislação não utiliza a classificação para os tipos de leite pasteurizado.

No leite tipo B, $3(33,3 \%)$ amostras analisadas estiveram em desacordo com a legislação do DIPOA (Brasil, 2002) e RIISPOA (Brasil, 1980). Os valores variaram de $<2$ a $2,4 \times 10^{1} \mathrm{NMP} / \mathrm{mL}$.

Os valores obtidos para leite tipo $\mathrm{C}$ variaram de $<2$ a $2 \mathrm{NMP} / \mathrm{mL}$, portanto de acordo com os padrões tolerados para coliformes fecais estabelecidos pelos órgãos mencionados. 
As amostras de leite cru apresentaram valores elevados nas 3 amostras analisadas, com variação entre 4,6 e 9,2 x 10² NMP de coliformes fecais/mL. Ao serem pasteurizadas no Laboratório de Microbiologia de Alimentos da ESALQ/USP, todas as amostras apresentaram valores $<2 \mathrm{NMP} / \mathrm{mL}$ de coliformes fecais, confirmando o benefício deste tratamento térmico na redução da carga bacteriana.

\subsubsection{Análise de $E$. coli pelo método SimPlate ${ }^{\circledR}$}

Pelo método SimPlate ${ }^{\circledR}$, o leite tipo A apresentou valores que variaram de $<2$ a 2,1 x $10^{1} \mathrm{NMP}$ de E.coli/mL, sendo que $4(44,4 \%)$ amostras analisadas apresentaram-se fora do padrão imposto pelo RIISPOA (Brasil, 1980) e pelo Departamento de Inspeção de Produtos de Origem Animal - DIPOA (Brasil, 2002). Quando comparado aos padrões da ANVISA (Brasil, 2001), 3 amostras (11,1\%) (1 do leite tipo A e 2 do tipo B) analisadas estiveram acima do valor preconizado, embora esta legislação não mencione os tipos de leite, classificando apenas como leite pasteurizado.

Para o leite tipo B, $3(33,3 \%)$ amostras analisadas na presente pesquisa apresentaram-se em desacordo à legislação do RIISPOA (Brasil, 1980) e do Departamento de Inspeção de Produtos de Origem Animal - DIPOA (Brasil, 2002). Os valores encontrados variaram de $<2$ a $1,7 \times 10^{1} \mathrm{NMP}$ de E.coli $/ \mathrm{mL}$.

Os valores encontrados para as amostras de leite tipo $\mathrm{C}$ analisadas variaram de $<2$ a 2 NMP de E.coli/mL sendo que nenhuma amostra esteve acima dos padrões previstos na legislação brasileira. Ao se realizar a pasteurização no laboratório de microbiologia de alimentos, todas as amostras, inclusive as de leite cru, apresentaram valores $<2$ NMP de E.coli $/ \mathrm{mL}$.

A presença de coliformes fecais acima dos limites estabelecidos pela legislação em muitas das amostras analisadas serve de alerta para o risco que a população está sujeita ao consumir leite pasteurizado. Cabe lembrar que a pasteurização do leite foi estabelecida para melhorar suas qualidades nutricionais evitando exposição ao calor excessivo da fervura e eliminando os microrganismos patogênicos acaso presentes. 
A presença de coliformes fecais acima dos limites estabelecidos pela legislação evidencia riscos quanto a presença de patógenos intestinais. Tais riscos devem servir como alerta aos órgãos fiscalizadores, para que melhores práticas de fabricação sejam implementadas, bem como melhor monitoramento de pontos críticos e de controle seja efetuado, a fim de que a população que consome tais produtos, não fique exposta a riscos de toxinfecções alimentares.

$\mathrm{O}$ número de amostras de leite tipo $\mathrm{A}$ e do tipo $\mathrm{B}$ analisadas no presente trabalho que se mostraram acima dos padrões legais quanto à enumeração de coliformes fecais, superaram os valores encontrados por Santos et al. (1999).

Nader Filho et al. (1997) revelaram que em 140 amostras de leite pasteurizado tipo A integral, processado por mini e micro-usinas, 19 (13,5\%) estavam acima do limite em relação aos coliformes fecais.

$\mathrm{Na}$ pesquisa de Tavares (1996) não foram encontrados coliformes fecais em 24 amostras de leite pasteurizado tipo A analisadas. Em 36 amostras de leite pasteurizado tipo B os valores variaram de 0,3 a 2,8 NMP de coliformes fecais/mL e em 48 amostras de leite pasteurizado tipo $\mathrm{C}$ os valores tiveram variação de 0,36 a 24 NMP de coliformes fecais $/ \mathrm{mL}$.

Neste trabalho, os percentuais de amostras de leite pasteurizado tipos A e B que estiveram fora dos padrões estabelecidos pela legislação vigente, quanto a coliformes fecais, superaram os encontrados por Santos et al. (1999) e Leite Jr \& Torrano (2000).

O número de amostras fora dos padrões na contagem de coliformes fecais no leite pasteurizado tipo $\mathrm{C}$ encontrado na presente pesquisa foi inferior aos determinados por Wendpap \& Rosa (1995), Nader Filho (1996), Wendpap \& Rosa (1997), Hoffman et al. (1999), Padilha \& Fernandes (1999), Santos et al. (1999), Leite Jr \& Torrano (2000) e Freitas et al. (2002). Os valores encontrados por esses pesquisadores variaram de 7,0 a $6,8 \times 10^{1} \mathrm{NMP} / \mathrm{mL}$.

No trabalho de Vieira et al. (1995), foi detectada a presença de coliformes fecais em 8 amostras de leite cru. Os valores estavam entre $2,8 \times 10^{1}$ e $9,4 \times 10^{2}$ 
NMP/mL Tanto os padrões do DIPOA (Brasil, 2002) e da ANVISA (Brasil, 2001) não citam parâmetros para leite cru.

Catão \& Ceballos (2001) evidenciaram elevada contaminação por coliformes totais e fecais em amostras de leite cru e pasteurizado. Das 30 amostras analisadas, 10 $(33,3 \%)$ apresentaram contaminação por coliformes totais e $3(10 \%)$ para coliformes fecais acima dos padrões vigentes.

Em 511 análises realizadas em leites tipos A, B e C, 94 (18,4\%) amostras de leite tipo $\mathrm{C}$ apresentaram-se acima do limite máximo preconizado para coliformes totais. Em relação aos coliformes fecais, 65 (12,7\%) amostras estiveram com contagens acima do limite para o leite tipo C (Santos, 1999).

Segundo Leite Jr. \& Torrano (1997) a variação sazonal evidencia as maiores ocorrências médias mensais para coliformes totais e fecais em leite. Para coliformes totais, as maiores médias, ocorreram no mês de abril, início do período chuvoso atingindo $8,9 \times 10^{1} \mathrm{NMP} / \mathrm{mL}$. Para coliformes fecais, as maiores médias foram verificadas no mês de junho, mês com elevada precipitação pluviométrica, atingindo valores de $2,3 \times 10^{1} \mathrm{NMP} / \mathrm{mL}$.

Considerando os padrões estipulados pelo RIISPOA (Brasil, 1980) para leite pasteurizado tipo C, das 30 amostras analisadas por Souza \& Cerqueira (1996), 2 (6,6\%) continham números de coliformes fecais superiores aos estabelecidos pela referida regulamentação.

Wendpap \& Rosa (1997) analisando o leite pasteurizado tipo C comercializado em Cuiabá, verificaram que, das cinco marcas avaliadas, quatro apresentaram contagens elevadas de coliformes totais e fecais, que deveriam ter sido eliminados durante o processamento térmico. Do total de 50 amostras analisadas, 15 (30\%) estiveram em desacordo aos padrões legais para coliformes totais e 9 (18\%) amostras para coliformes fecais. Comparando estes resultados à pesquisa de Wendpap \& Rosa (1995), referentes às mesmas determinações, observa-se que 20 (40\%) unidades amostrais apresentaram coliformes totais e $6(12 \%)$ amostras coliformes fecais, acima dos padrões legais vigentes. 
Normalmente o leite tipo C é considerado um produto de baixa qualidade, já que a matéria-prima possui deficiência higiênico-sanitária na sua produção.

Barros et al. (1999), ao analisarem 38 amostras de leite tipo C provenientes de pequenas fazendas, observaram que $6(15,8 \%)$ apresentavam contagens microbiológicas elevadas para coliformes fecais.

Freitas et al. (2002), ao analisarem 51 amostras de leite do tipo C, verificaram que $17(33,3 \%)$ amostras excederam aos padrões microbiológicos em relação a coliformes fecais.

Leite et al. (2002) observaram que, das 20 amostras de leite tipo $\mathrm{C}$ analisadas, $13(65 \%)$ amostras apresentaram contaminações por coliformes totais com valores variando de 4 a 2,4 x $10^{3} \mathrm{NMP} / \mathrm{mL}$. Quanto aos coliformes fecais, obteve-se um resultado de 7 (35\%) amostras contaminadas, com valores que variaram de 9 a 2,4 x $10^{3}$ $\mathrm{NMP} / \mathrm{mL}$, estando, portanto, em condições inaceitáveis.

\subsection{Comparação entre os métodos tubos múltiplos e SimPlate ${ }^{\circledR}$}

Para a enumeração de coliformes totais e fecais, o coeficientes de correlação entre os métodos avaliados foram considerados bons (Tabela 7, Figuras 14 e 15).

Townsend \& Naqui (1998) explicam que o NMP do SimPlate ${ }^{\circledR}$ utiliza o mesmo príncipio matemático que o NMP convencional pela técnica dos tubos múltiplos, porém é mais preciso devido ao grande número de cavidades disponíveis nas placas SimPlate ${ }^{\circledR}$. Assim, o NMP determinado por SimPlate ${ }^{\circledR}$ é altamente correlacionado com métodos de contagens de colônias. Os dados obtidos no presente trabalho reforçam a afirmativa de que o coeficiente de correlação encontrado entre NMP dos tubos múltiplos e do SimPlate ${ }^{\circledR}$, bem como os valores de intercepto e inclinação foram satisfatórios.

Dessa maneira, pode-se aceitar que, para coliformes totais, 92,89\% dos resultados obtidos por tubos múltiplos podem ser relacionados com os dados gerados por SimPlate ${ }^{\circledR}$. Da mesma forma, para coliformes fecais, 97,11\% dos resultados dos tubos múltiplos podem ser relacionados com os dados do SimPlate ${ }^{\circledR}$. Esta alta correlação deixa 
claro que os coliformes fecais estimados pela técnica dos tubos múltiplos se referiam quase que exclusivamente a $E$. coli, que é a bactéria coliforme fecal detectada pela técnica do SimPlate ${ }^{\circledR}$.

Barancelli (2002) ao realizar análise estatística para comparação desses dois métodos para coliformes totais, encontrou em 27 amostras analisadas, coeficiente de correlação 0,95, coeficiente angular 0,93 e coeficiente linear 0,36. Em comparação com a presente pesquisa, os valores foram semelhantes.

Tabela 7. Resumo das comparações estatísticas entre os métodos NMP (tubos múltiplos) e SimPlate ${ }^{\circledR}$ para contagem de coliformes totais e fecais/E. coli nas amostras de leite tipos A, B, C e cru

\begin{tabular}{ccc}
\hline $\begin{array}{c}\text { Medida } \\
\text { de performance }\end{array}$ & $\begin{array}{c}\text { Tubos múltiplos } \mathbf{x} \\
\text { SimPlate (Totais) }\end{array}$ & $\begin{array}{c}\text { Tubos múltiplos x } \\
\text { SimPlate (Fecais/E. coli) }\end{array}$ \\
\hline Coeficiente de correlação & 0,9289 & 0,9711 \\
Coeficiente angular & 0,9015 & 0,8110 \\
Coeficiente linear & 0,0761 & 0,038 \\
Número de amostras & 30 & 30 \\
\hline
\end{tabular}

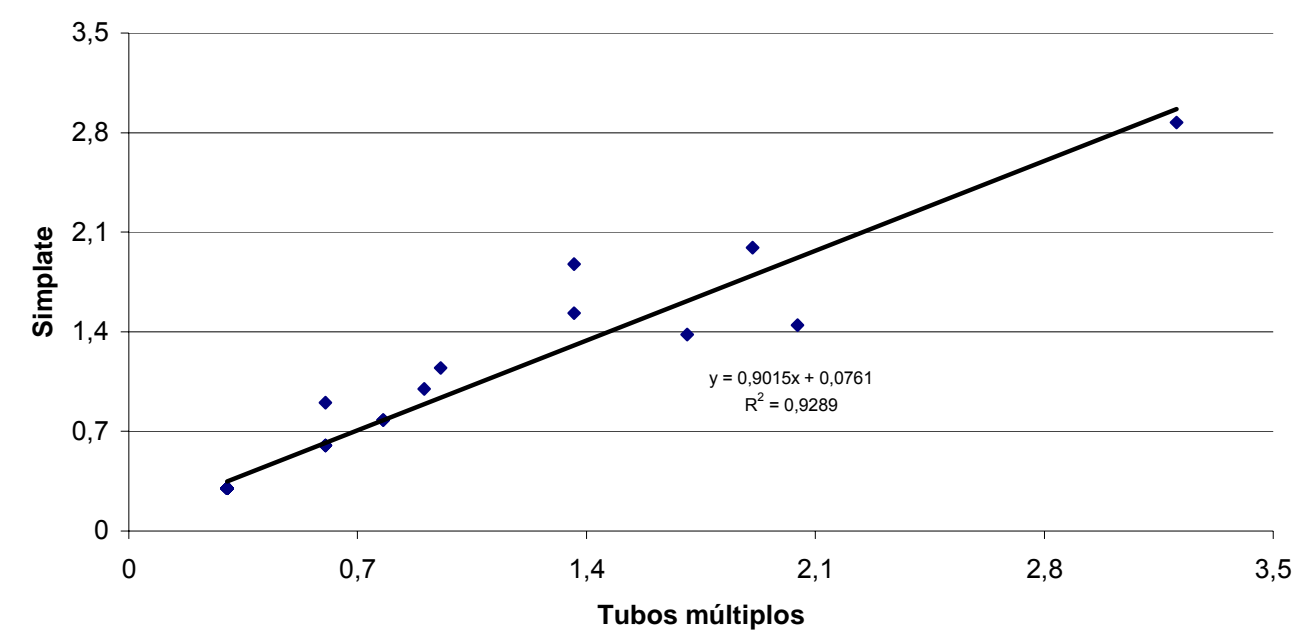

Figura 14 - Dispersão dos resultados das contagens (NMP) de coliformes totais em leite tipos A, B, C e cru obtidos pelos métodos NMP (tubos múltiplos) e SimPlate ${ }^{\circledR}$ 


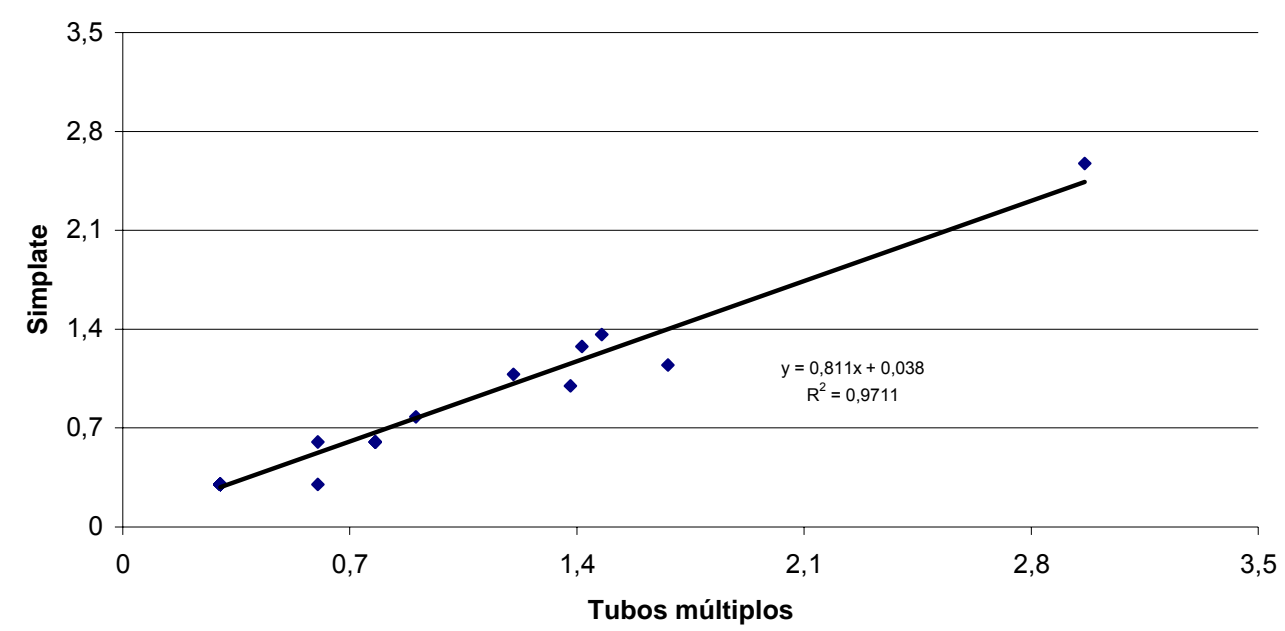

Figura 15 - Dispersão dos resultados das contagens (NMP) de coliformes fecais/E. coli em leite tipos A, B, C e cru obtidos pelos métodos NMP (tubos múltiplos) e SimPlate ${ }^{\circledR}$

\subsection{Contagem de Staphylococcus coagulase positiva}

Os resultados obtidos para as contagens de Staphylococcus coagulase positiva para leite tipos A, B, C e cru, encontram-se na Tabela 8. A legislação não prevê um parâmetro aceitável para este grupo de bactérias para o leite, mas estabelece limites para outros alimentos que situam-se entre $10^{2}$ e $10^{3} \mathrm{UFC} / \mathrm{g}$ ou $\mathrm{mL}$. Isso, provavelmente, se deve ao fato de que na literatura é citado que valores normalmente acima de $10^{6}$ UFC de S. aureus são normalmente necessários para a detecção de enterotoxinas no alimento. 
Tabela 8. Contagens de Staphylococcus coagulase positiva obtidas em amostras de leite adquiridas no comércio local de Piracicaba antes e após pasteurização em laboratório

\begin{tabular}{|c|c|c|}
\hline Amostras & $\begin{array}{c}\text { Staphylococcus coag. positiva } \\
\text { (UFC/mL) }\end{array}$ & $\begin{array}{l}\text { Staphylococcus coag. positiva Past } \\
\text { (UFC/mL) }\end{array}$ \\
\hline A I 1 & $1,0 \times 10^{1}$ & 0 \\
\hline A I 2 & 0 & 0 \\
\hline A I 3 & $1,1 \times 10^{2}$ & 0 \\
\hline A II 4 & $3,0 \times 10^{1}$ & 0 \\
\hline A II 5 & $1,1 \times 10^{1}$ & 0 \\
\hline A II 6 & 0 & 0 \\
\hline A III 7 & 0 & 0 \\
\hline A III 8 & 0 & 0 \\
\hline A III 9 & 0 & 0 \\
\hline média & $1,8 \times 10^{1}$ & 0 \\
\hline B I 1 & 0 & 0 \\
\hline B I 2 & 0 & 0 \\
\hline B I 3 & $8,0 \times 10^{1}$ & 0 \\
\hline B II 4 & 0 & 0 \\
\hline B II 5 & 0 & 0 \\
\hline B II 6 & 0 & 0 \\
\hline B III 7 & 0 & 0 \\
\hline B III 8 & 0 & 0 \\
\hline B III 9 & 0 & 0 \\
\hline média & 8,9 & 0 \\
\hline C I 1 & $1,0 \times 10^{1}$ & 0 \\
\hline C I 2 & $2,0 \times 10^{1}$ & 0 \\
\hline C I 3 & $1,0 \times 10^{1}$ & 0 \\
\hline C II 4 & $2,0 \times 10^{1}$ & 0 \\
\hline C II 5 & 0 & 0 \\
\hline C II 6 & 0 & 0 \\
\hline C III 7 & $3,0 \times 10^{1}$ & 0 \\
\hline C III 8 & 0 & 0 \\
\hline C III 9 & 0 & 0 \\
\hline média & $1,0 \times 10^{1}$ & 0 \\
\hline Cru 1 & $3,0 \times 10^{1}$ & 0 \\
\hline Cru 2 & $4,0 \times 10^{1}$ & 0 \\
\hline Cru 3 & $1,1 \times 10^{2}$ & 0 \\
\hline média & $6,0 \times 10^{1}$ & 0 \\
\hline
\end{tabular}

A-B-C-Cru: tipos de leite

I-II-III: marca

Números: número de amostras 
Na presente pesquisa foram analisadas amostras de leite pasteurizado tipos A, $\mathrm{B}$ e $\mathrm{C}$, e que, por sofrerem esse tipo de tratamento térmico, não poderiam apresentar bactéria potencialmente patogênica, como Staphylococcus aureus e/ou Staphylococcus coagulase positiva.

Embora o maior valor encontrado tenha sido de $1,1 \times 10^{2} \mathrm{UFC} / \mathrm{mL}$ e, portanto, longe da dose infectiva, preocupa o fato por ser o leite considerado um ótimo substrato para bactérias. Portanto, quando submetido a condições inadequadas de tempo e temperatura, pode permitir uma rápida multiplicação das mesmas. Assim, o risco de Staphylococcus potencialmente patogênicos atingirem níveis elevados e produção de toxinas em condições inadequadas, poderia levar a casos de intoxicação no caso de ingestão de tais amostras.

As amostras de leite cru analisadas e que apresentaram altas contaminações bacterianas, mostrando-se em condições higiênico-sanitárias insatisfatórias, após a pasteurização, apresentaram reduções elevadas das bactérias e eliminação de patógenos, como os Staphylococcus coagulase positiva, colocando-as em condições satisfatórias para o consumo humano, mostrando o grande benefício trazido pela pasteurização do leite.

Outro fato preocupante, é que a detecção desse grupo de bactérias evidencia falhas no processo de pasteurização, uma vez que essas bactérias são destruídas por esse processo. Após a pasteurização das amostras de leite no laboratório $\left(62,8^{\circ} \mathrm{C} / 30^{\prime}\right)$ nenhuma delas apresentou Staphylococcus coagulase positiva.

Ao examinar os resultados da Tabela 8 , nota-se que 44,4\% das amostras de leite tipo A analisadas apresentaram Staphylococcus coagulase positiva, bem como $11,1 \%$ das amostras de leite tipo B e 55,6\% das amostras de leite tipo C.

As gôndolas dos estabelecimentos comerciais, nas quais as amostras de leite tipos $\mathrm{A}, \mathrm{B}$ e $\mathrm{C}$ analisadas nos presente trabalho foram adquiridas, mostraram uma variação de temperatura entre 7 e $8^{\circ} \mathrm{C}$. Tais valores de temperatura demonstram boas condições de armazenamento do leite durante a comercialização. Entretanto, nada pode ser afirmado a respeito das condições durante a distribuição do produto, uma vez que essa fase não foi monitorada. 
$\mathrm{Na}$ literatura, o leite aparece como alimento envolvido em surtos de toxinfecções alimentares. Os dados obtidos no presente trabalho, com detecção, embora em números baixos de Staphylococcus coagulase positiva, nas amostras de leite tipos A, B e C, adquiridos no comércio de Piracicaba, alertam para potencial risco de intoxicação alimentar, caso condições adequadas de comercialização não sejam seguidas.

No trabalho de Leite et al. (2002) não foi observada a presença de Staphylococcus coagulase positiva em leite integral pasteurizado tipo C.

Wendpap \& Rosa (1997) também não encontraram Staphylococcus coagulase positiva em 5 marcas de leite tipo $\mathrm{C}$, em um total de 50 amostras analisadas.

No entanto, das 511 amostras de leite pasteurizado analisadas por Santos et al. (1999), 167 amostras foram submetidas à pesquisa de Staphylococcus coagulase positiva, sendo que $24(14,4 \%)$ destas apresentaram resultado positivo assim distribuídos: 1 amostra de leite pasteurizado tipo A, 5 de tipo B, 16 do tipo C e 2 amostras de leite desnatado. A variação do número desses microrganismos obtida em $\mathrm{NMP} / \mathrm{mL}$, foi: tipo A $(0,36)$, tipo B $(0,3$ a 9,3), tipo C $(0,3$ a 4,4) e desnatado (de 0,76 a 2,1). Tais valores são inferiores aos detectados na presente pesquisa, onde para as amostras de leite tipo A os valores variaram entre $<10$ a $1,1 \times 10^{2} \mathrm{UFC} / \mathrm{mL}$; as do tipo $\mathrm{B}$ entre $<10$ a $8,0 \times 10^{1} \mathrm{UFC} / \mathrm{mL}$ e as do tipo $\mathrm{C}$ entre $<10$ a $3,0 \times 10^{1} \mathrm{UFC} / \mathrm{mL}$.

\subsection{Deteç̧ão de Salmonella}

Em nenhuma das amostras de leite analisadas no presente trabalho foi detectada a presença de Salmonella em $25 \mathrm{~mL}$, atendendo, portanto, as legislações em vigor, ou seja, a Resolução RDC nº12 da ANVISA (Brasil, 2001) e a Instrução Normativa $\mathrm{n}^{\circ} 51$ do DIPOA (Brasil, 2002).

A incidência real de Salmonella nas toxinfecções alimentares é desconhecida, uma vez que pequenos surtos não são freqüentemente relatados para as autoridades de saúde pública (Giombelli \& Silva, 2001).

No trabalho de Wendpap \& Rosa (1997) não foi encontrada Salmonella em 5 marcas de leite tipo $\mathrm{C}$, em um total de 50 amostras analisadas. 
Também Freitas et al. (2002) e Santos et al. (1999), ao analisarem amostras de leite pasteurizado não encontraram Salmonella em $25 \mathrm{~mL}$ do produto, mostrando que tais amostras se encontraram em acordo com os padrões legais vigentes.

Leite et al. (2002), também não encontraram amostras do leite pasteurizado tipo C contaminadas por Salmonella.

Hoffman et al. (1999), no entanto, detectaram a presença de Salmonella em $21,4 \%$ das 28 amostras de leite tipo C analisadas.

\subsection{Condições microbiológicas gerais das amostras de leite pasteurizado analisadas}

Na Tabela 9 são apresentados os números de amostras e as porcentagens de leite $\mathrm{A}, \mathrm{B}$ e $\mathrm{C}$ em desacordo com os padrões microbiológicos estabelecidos pela legislação do DIPOA (Brasil, 2002), atualmente em vigor. A legislação imposta pela ANVISA (Brasil, 2001) não menciona todos os parâmetros microbiológicos, portanto não foi utilizada aqui, assim como os parâmetros do RIISPOA (Brasil, 1980), que não estão mais em vigor.

Tabela 9. Amostras de leite pasteurizado tipos A, B, C em desacordo com os padrões microbiológicos estabelecidos pelo DIPOA (Brasil, 2002)

\begin{tabular}{ccccccc}
\hline $\begin{array}{c}\text { Tipos } \\
\text { de } \\
\text { Leite }\end{array}$ & $\begin{array}{c}\text { Amostras } \\
\text { analisadas }\end{array}$ & & Padrões Bacteriológicos & & $\begin{array}{c}\text { Amostras } \\
\text { em } \\
\text { desacordo }\end{array}$ \\
\hline \multicolumn{1}{c}{} & \multicolumn{1}{c}{$\begin{array}{c}\text { Contagem } \\
\text { Padrão }\end{array}$} & $\begin{array}{c}\text { Coliformes } \\
\text { Totais }\end{array}$ & $\begin{array}{c}\text { Coliformes } \\
\text { Fecais }\end{array}$ & Salmonella & \\
\hline A & 9 & $4(44,4 \%)$ & $6(66,7 \%)$ & $5(55,6 \%)$ & 0 & $15(41,7 \%)$ \\
B & 9 & 0 & $3(33,3 \%)$ & $3(33,3 \%)$ & 0 & $6(16,7 \%)$ \\
C & 9 & 0 & 0 & 0 & 0 & $0(0 \%)$ \\
\hline
\end{tabular}

Observa-se na Tabela 9, que 41,7\% das amostras de leite pasteurizado tipo A estiveram em desacordo com os padrões microbiológicos do DIPOA (Brasil, 2002) utilizados. Nas amostras de leite tipo B, 16,7\% estiveram em desacordo com a legislação citada. Já as amostras de leite tipo C analisadas, apresentaram os melhores resultados, 
pois todas as amostras seriam aprovadas no caso de uma inspeção. Normalmente este tipo de leite pode ser produzido em qualquer tipo de propriedade, com inspeção periódica do rebanho. A ordenha normalmente é manual e o resfriamento do leite não é obrigatório. Também, não há menção de tempo máximo entre ordenha e transporte para o beneficiamento.

Há que se levar em conta que o maior índice de reprovação das amostras do leite tipo A, tem como uma das causas a maior exigência da legislação em relação aos outros tipos de leite. Porém, vale salientar que o consumidor pagou mais caro (praticamente o dobro do preço) pelo leite do tipo A. O valor em reais (R\$) do leite tipo A varia nos estabelecimentos comerciais, mas em média o preço é R \$ 1,90/litro. O leite tipo $\mathrm{C}$ custa de $\mathrm{R} \$ 0,80$ a $\mathrm{R} \$ 1,00$. Pelo fato dos padrões microbiológicos para o leite $\mathrm{C}$ serem menos rigorosos, teoricamente é mais fácil de se manter dentro dos padrões. Ainda pode ser discutido que um leite tipo A rejeitado ou fora dos padrões não é necessariamente um leite de pior qualidade microbiológica que um leite tipo $\mathrm{C}$ dentro das normas. Mas de qualquer maneira, as pessoas estão comprando leite A esperando uma qualidade superior e que não está sendo mantida, se forem observados os resultados da presente pesquisa.

Ainda, existem especificações e medidas a serem adotadas para a obtenção de um leite tipo A e que se forem rigorosamente seguidas, o produto irá atender as exigências legais. Portanto, não se justifica que um \% tão elevado de amostras de leite pasteurizado tipo A não tenha se apresentado em acordo com os padrões microbiológicos vigentes no país.

Em relação à contagem de bactérias mesófilas aeróbias, somente as amostras do leite tipo A apresentaram valores acima dos tolerados, com 44,4\% das amostras em desacordo com os padrões estabelecidos pelo DIPOA (Brasil, 2002) e 55,6\% em desacordo com os padrões do RIISPOA (Brasil, 1980). Diferentemente do esperado, as amostras de leite tipo $\mathrm{C}$ analisadas, mostraram-se em vários parâmetros microbiológicos, em melhores condições do que amostras de leite tipos A e B (Figuras 16, 17 e 18).

Em relação às análises realizadas para a enumeração do número mais provável de coliformes totais, $66,7 \%$ das amostras de leite pasteurizado tipo A, 33,3\% das 
amostras de leite tipo B e nenhuma das amostras de leite tipo $\mathrm{C}$, estiveram em desacordo com os padrões mencionados pelo Departamento de Inspeção de Produtos de Origem Animal - DIPOA (Brasil, 2002) (Figuras 16, 17 e 18).

A enumeração de coliformes fecais mostrou que 55,6\% das amostras de leite A, 33,3\% das amostras de leite B e nenhuma das amostras de leite C, estavam com valores acima dos tolerados pelos padrões legais vigentes (Figuras 16, 17 e 18).

Contagem padrão em placas

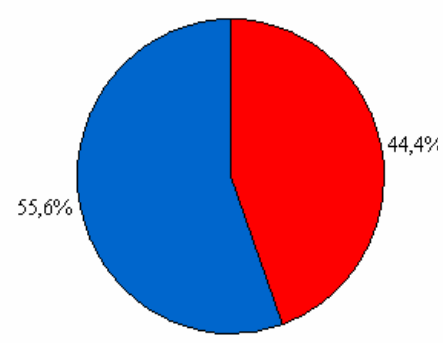

$\square \%$ acima do limite $\square \%$ aprovado

Coliformes fecais

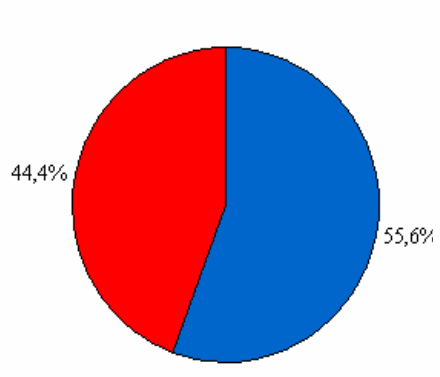

¿\% acima do limite $\square \%$ aprovado
Coliformes totais

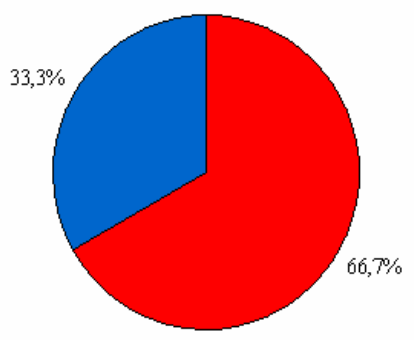

$\square \%$ acima do limite $\square \%$ aprovado

Salmonella

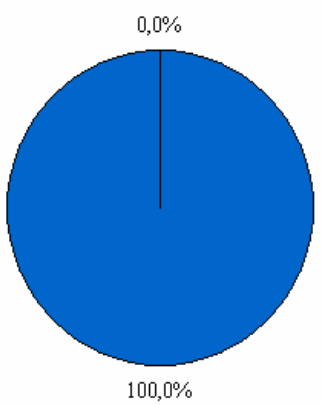

$\square \%$ acima do limite $\square \%$ aprovado

Figura 16 - Porcentagens de amostras de leite pasteurizado tipo A acima e dentro dos limites microbiológicos do DIPOA (Brasil, 2002) 
Contagem padrão em placas

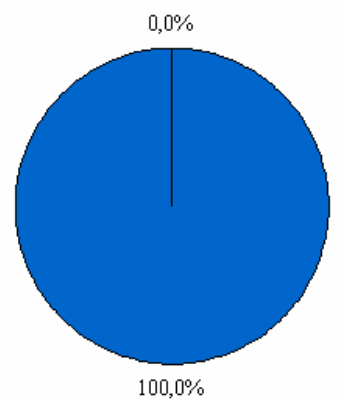

प\% acima do limite $\square \%$ aprovado

Coliformes fecais

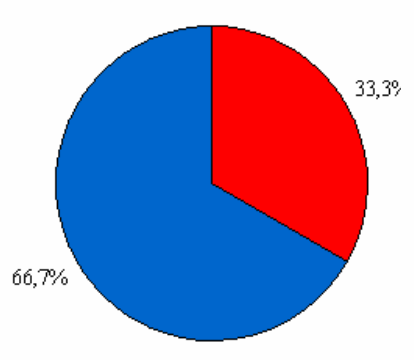

$\square \%$ acima do limite $\square \%$ aprovado
Coliformes totais

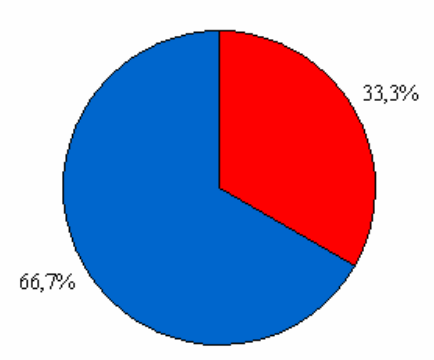

$\square \%$ acima do limite $\square \%$ aprovado

Salmonella

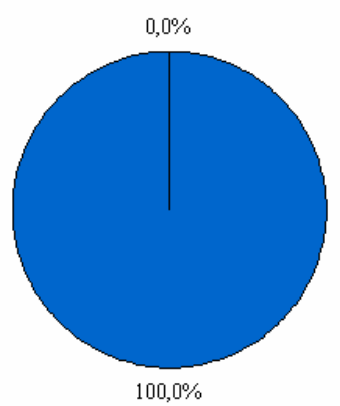

$\square \%$ acima do limite $\square \%$ aprovado

Figura 17 - Porcentagens de amostras de leite pasteurizado tipo B acima e dentro dos limites microbiológicos do DIPOA (Brasil, 2002) 
Contagem padrão em placas

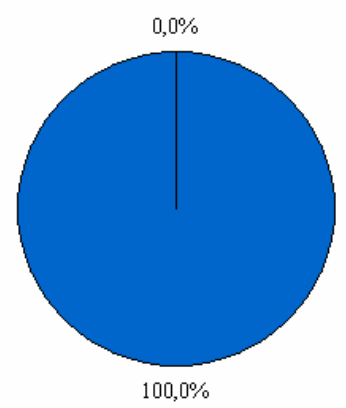

$\square \%$ acima do limite $\square \%$ aprovado

Coliformes fecais

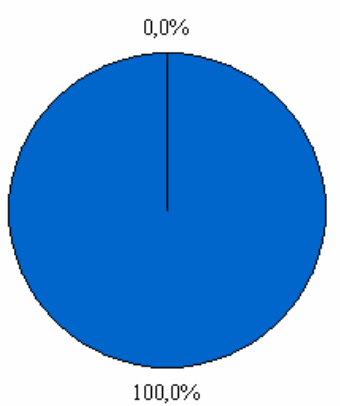

$\square \%$ acima do limite $\square \%$ aprovado
Coliformes totais

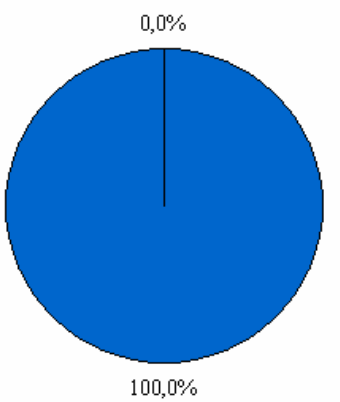

$\square \%$ acima do limite $\square \%$ aprovado

Salmonella

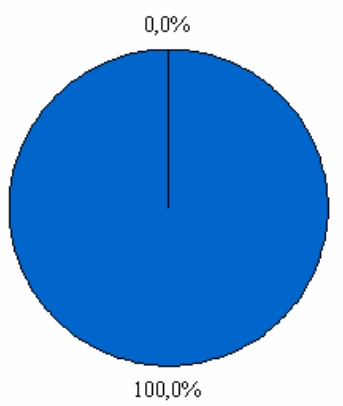

प\% acima do limite $\square \%$ aprovado

Figura 18 - Porcentagens de amostras de leite pasteurizado tipo $\mathrm{C}$ acima e dentro dos limites microbiológicos do DIPOA (Brasil, 2002)

Os padrões estabelecidos pela ANVISA (Brasil, 2001) para coliformes fecais (coliformes a $45^{\circ} \mathrm{C}$ ) em leite pasteurizado são bem mais tolerantes que os demais mencionados. Vale notar que a ANVISA usa a classificação leite pasteurizado não mencionando os tipos de leite, portanto, 4 (14,8\%) amostras de leite pasteurizado, (1 do leite tipo A e 3 do leite tipo B) (Figura 19) estariam em desacordo com os padrões da ANVISA (Brasil, 2001). 
Coliformes a $45^{\circ} \mathrm{C}$

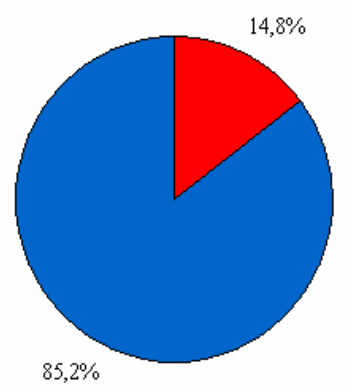

$\square \%$ acima do limite $\square \%$ aprovado
Salmonella

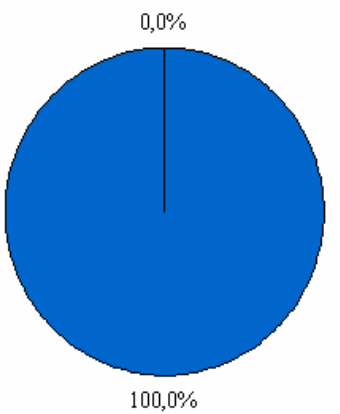

$\square \%$ acima do limite $\square \%$ aprovado

Figura 19 - Porcentagens de amostras de leite tipo pasteurizado acima e dentro dos limites microbiológicos da ANVISA (Brasil, 2001)

Observa-se que nenhuma amostra de leite analisada no presente trabalho, tanto pasteurizado como cru, apresentou Salmonella em $25 \mathrm{~mL}$, o que as coloca em acordo com os três padrões utilizados (RIISPOA, ANVISA e DIPOA).

As amostras analisadas evidenciaram a necessidade de uma melhor orientação e fiscalização da produção e comercialização principalmente do leite tipo A. A maioria dos pesquisadores citados encontrou índices de contaminação maiores principalmente em amostras de leite tipo C. Os resultados das análises microbiológicas encontrados no presente trabalho para leite pasteurizado tipo $\mathrm{C}$ foram de um modo geral melhores, quando comparados aos encontrados para leite pasteurizado tipos A e B.

Segundo Tavares (1996) as amostras de leite pasteurizado tipo A, mostraram melhores condições higiênico-sanitárias em relação às dos tipos $\mathrm{B}$ e $\mathrm{C}$, porém as contagens de microrganismos mesófilos estiveram em altos percentuais acima dos padrões normais de vigilância. Os leites tipos A e B apresentaram más condições higiênico-sanitárias. Entre os leites tipos $\mathrm{B}$ e $\mathrm{C}$ observou-se diferenças em relação às condições microbiológicas, sendo que em certas amostras a contaminação foi maior no leite tipo B. 
Apesar de algumas diferenças em relação aos percentuais de amostras de leite pasteurizado que se apresentaram fora dos padrões microbiológicos vigentes, nota-se que mesmo decorridos 9 anos após a pesquisa de Tavares (1996), a qualidade microbiológica de leite pasteurizado comercializado em Piracicaba, continua deixando muito a desejar.

Brandão \& Reis Jr. (1995) reportam que em países desenvolvidos não se admite que o leite, sendo um produto destinado principalmente às camadas sociais consideradas de risco, seja obtido sem condições mínimas de higiene, estabelecidas pelo governo. Esclarecem ainda que, em países desenvolvidos só existe leite tipo A e defendem a mudança da legislação brasileira para eliminação dos leites tipos B e C, para o surgimento de um novo tipo de leite A. Consideram inadmissível que no século XXI ainda esteja sendo produzido leite tipo C.

Vale notar que em países subdesenvolvidos essa afirmação não pode ser aplicada, pois as camadas pobres não teriam condições financeiras de consumir leite tipo A. Nota-se que para produzir leite esterilizado não precisa utilizar leite tipo A, assim como para os derivados do leite. Também é importante salientar que a qualidade de um produto não pode ser resolvida somente pela legislação.

$\mathrm{Na}$ atualidade a ferramenta mais avançada para proteger os produtos alimentícios de perigos microbiológicos, físicos e químicos é o sistema de análise de perigos e pontos críticos de controle (HACCP). Com base científica, o sistema tem por finalidade identificar perigos específicos e estabelecer medidas preventivas de controle em toda a cadeia alimentar, envolvendo a produção primária, as indústrias, os transportadores, os consumidores, os inspetores e fiscalizadores e os fornecedores de produtos e serviços de qualquer natureza que se relacione com a segurança do alimento (Freitas et al, 2002; Leite Jr \& Torrano, 2000; Santos et al.,1999). 
Torna-se evidente que problemas sanitários têm ocorrido na obtenção, tratamento e conservação do leite e, portanto, devem ser implementadas medidas com ações que possam identificar falhas no processo de obtenção do produto e maior rigor na fiscalização pelos órgãos competentes. Devem também serem implantados programas de qualidade que garantam um controle efetivo das condições higiênico-sanitárias das indústrias durante todo o processo até a distribuição e comercialização, para obtenção de um produto de melhor qualidade para a população.

\subsection{Eficácia da pasteurização}

A Tabela 10 mostra a eficácia da pasteurização, realizada no Laboratório de Microbiologia de Alimentos da ESALQ-USP, em relação aos microrganismos aeróbios mesófilos, termófilos e psicrotróficos. Também foi feita a média dos valores de reduções logarítmicas para os tipos de leite analisados (Figura 20) para melhor visualização dos dados. 
Tabela 10. Eficácia da pasteurização $(\log )$ realizada no laboratório, das amostras de leite tipos A, B, C e cru obtidas no comércio de Piracicaba

\begin{tabular}{cccc}
\hline Amostras & Mesófilos & Termófilos & Psicrotróficos \\
\hline A I 1 & 0,97 & 0,77 & 1,17 \\
A I 2 & 0,56 & 0 & 0,42 \\
A I 3 & 2,95 & 0,72 & 1,47 \\
A II 4 & 0,99 & 0,25 & 2,13 \\
A II 5 & 0,11 & 0,23 & 1,78 \\
A II 6 & 0,56 & 0,25 & 2,00 \\
A III 7 & 0,99 & 0 & 1,07 \\
A III 8 & 0,43 & 0,78 & 1,82 \\
A III 9 & 0,82 & 0 & 1,02 \\
média & 1,03 & 0,41 & 1,43 \\
B I 1 & 0,39 & 0,93 & 1,91 \\
B I 2 & 0,30 & 0 & 1,45 \\
B I 3 & 1,03 & 0 & 2,57 \\
B II 4 & 0,74 & 0,54 & 1,27 \\
B II 5 & 1,09 & 0,23 & 1,49 \\
B II 6 & 0,95 & 0,15 & 1,78 \\
B III 7 & 1,47 & 0,84 & 1,27 \\
B III 8 & 1,32 & 0,93 & 0,84 \\
B III 9 & 1,68 & 0,78 & 1,49 \\
média & 0,99 & 0,49 & 1,56 \\
C I 1 & 0,56 & 0 & 1,11 \\
C I 2 & 1,17 & 0,93 & 1,64 \\
C I 3 & 1,15 & 0,78 & 0,92 \\
C II 4 & 0,99 & 0,24 & 1,05 \\
C II 5 & 0,85 & 0,78 & 1,77 \\
C II 6 & 0,82 & 0,26 & 1,23 \\
C III 7 & 1,03 & 0,26 & 0,97 \\
C III 8 & 1,73 & 0,25 & 1,01 \\
C III 9 & 1,65 & 0,26 & 0,97 \\
média & 1,11 & 0,42 & 1,19 \\
Cru 1 & 4,91 & 0,15 & 1,75 \\
Cru 2 & 5,05 & 0 & 3,51 \\
Cru 3 & 2,88 & 0,12 & 3,08 \\
média & 4,28 & 0,09 & 2,78 \\
\hline A-C-Crus & &
\end{tabular}

A-B-C-Cru: tipos de leite

I-II-III: marca

Números: número de amostras 


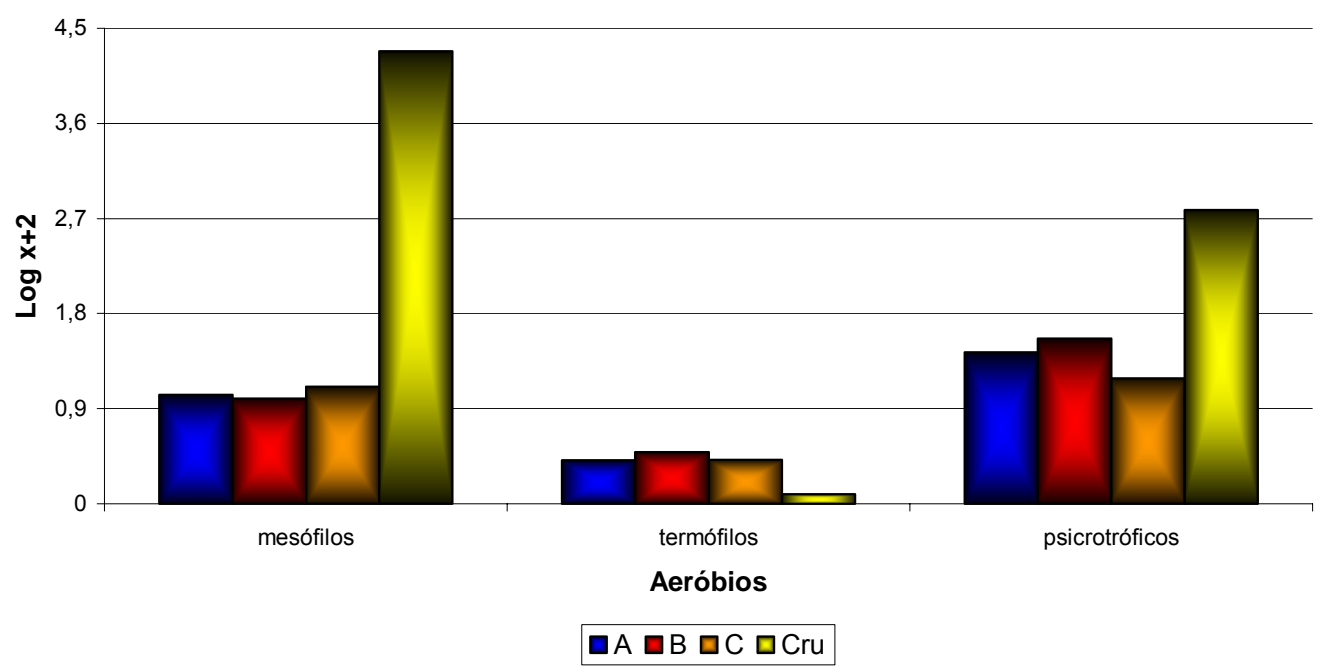

Figura 20 - Médias das reduções logarítmicas conseguidas pela pasteurização realizada no laboratório para as amostras de leite pasteurizado tipos A, B, C e leite cru

Pelos resultados apresentados na Tabela 10, fica claro que a pasteurização das amostras de leite realizada no Laboratório de Microbiologia de Alimentos do Departamento de Agroindústria, Alimentos e Nutrição da ESALQ, reduziu todos os grupos de microrganismos analisados. Assim, as reduções de microrganismos mesófilos sofreram variações de 0,11 a 2,94 ciclos logarítmicos (leite tipo A), 0,38 a 1,68 (leite tipo B), 0,55 a 1,72 (leite tipo C) e 2,87 a 5,05 (leite cru).

Para as contagens de microrganismos psicrotróficos as reduções variaram de 0,41 a 2,13 ciclos logarítmicos (leite tipo A), 0,84 a 2,57 (leite tipo B), 0,92 a 1,77 (leite tipo C) e 1,17 a 3,51 (leite cru). Em face dessas reduções elevadas encontradas para esses grupos microbianos, hipóteses como: falhas do binômio tempo/temperatura durante a pasteurização industrial; matéria-prima excessivamente contaminada, sanificação deficiente das linhas de produção, transporte e armazenamento em temperaturas inadequadas, e/ou contaminação pós-pasteurização, podem ser levantadas para as amostras de leite pasteurizado tipos $\mathrm{A}, \mathrm{B}$ e $\mathrm{C}$ adquiridas no comércio do município de Piracicaba. 
Se essas amostras tivessem sido adequadamente processadas na pasteurização industrial, provavelmente os termodúricos sobreviventes não seriam tão sensíveis a uma segunda pasteurização. Portanto, devem ter sobrevivido microrganismos que deveriam ter sido destruídos e provavelmente aumentaram em número após a pasteurização por algum dos motivos expostos e foram eliminados significativamente durante a outra pasteurização no laboratório. Até porque como já discutido anteriormente, a detecção de prováveis patógenos, como por exemplo, Staphylococcus coagulase positiva em algumas amostras de leite pasteurizado adquiridas no comércio deixa claro que ou aconteceram falhas no processo de pasteurização, ou aconteceu recontaminação após o tratamento térmico. Diante disso, vale mais uma vez lembrar da necessidade de uma fiscalização maior e orientação para boas práticas de fabricação e monitoramento de pontos críticos e de risco, para que a população não fique exposta a problemas de toxinfecções alimentares, pela ingestão desse tipo de alimento.

Como era de se esperar, uma vez que a pasteurização exerce efeito marcante sobre psicrotróficos e mesófilos, as reduções encontradas para os microrganismos termófilos foram bem menores, com reduções variando de 0 a 0,92 ciclos logarítmicos para as amostras de leite tipos A, B, C e cru. 


\section{CONCLUSÕES}

1 O número de amostras acima do limite estabelecido pelo DIPOA (Brasil, 2002) para microrganismos mesófilos do leite tipo A $(44,4 \%)$, foi maior em relação às amostras de leite tipos B $(0,0 \%)$ e C $(0,0 \%)$.

2 Embora sem padrões legais vigentes atualmente, as contagens de psicrotróficos $(1,2 \mathrm{x}$ $10^{1}$ a $\left.8,5 \times 10^{3} \mathrm{UFC} / \mathrm{mL}\right)$ e de termófilos ( $<10$ a $\left.1,6 \times 10^{2} \mathrm{UFC} / \mathrm{mL}\right)$, encontradas nas amostras de leite pasteurizado tipos A, B, C e leite cru analisadas, foram baixas.

3 Utilizando-se a metodologia dos tubos múltiplos, $6(66,7 \%)$ amostras de leite tipo A, $3(33,3 \%)$ amostras de leite tipo B e $0(0,0 \%)$ amostras de leite tipo C, apresentaram NMP de coliformes totais acima dos padrões estabelecidos pelo DIPOA (Brasil, 2002). Quando a metodologia SimPlate foi utilizada, os mesmos percentuais de amostras analisadas foram encontrados como fora dos padrões do referido órgão.

4 Utilizando-se a metodologia dos tubos múltiplos, 5 (55,6\%) amostras de leite tipo A, $3(33,3 \%)$ amostras de leite tipo B e $0(0,0 \%)$ amostras de leite tipo C, apresentaram NMP de coliformes fecais acima dos padrões estabelecidos pelo DIPOA (Brasil, 2002). Quando a metodologia SimPlate ${ }^{\circledR}$ foi utilizada, 4 (44.4\%) amostras de leite tipo A, $3(33,3 \%)$ amostras de leite tipo B e $0(0,0 \%)$ amostras de leite tipo C, apresentaram NMP de E. coli acima dos mesmos padrões para coliformes fecais.

5 A análise estatística feita para os valores de NMP (tubos múltiplos) e NMP (SimPlate) mostrou uma alta correlação entre esses métodos, tanto para a 
determinação de coliformes totais como de coliformes fecais e/ou E. coli.

6 Se os padrões microbiológicos da ANVISA (Brasil, 2001) forem considerados, o número de amostras que apresentaram valores de coliformes a $45^{\circ} \mathrm{C}$ e/ou E. coli, acima dos valores máximos estabelecidos será bem menor, já que tal legislação é menos exigente nesse quesito para leite pasteurizado. Assim, apenas 4 amostras (1 tipo A e 3 tipo $B=14,8 \%$ ) de todas as analisadas estariam com NMP de coliformes a $45^{\circ} \mathrm{C}$ acima dos padrões, quando a metodologia utilizada foi a dos tubos múltiplos. Se a metodologia considerada for a do SimPlate ${ }^{\circledR}$, apenas 3 amostras ( 1 tipo A e 2 tipo $\mathrm{B}=11,1 \%$ ) estariam com NMP de E.coli acima dos padrões da ANVISA (Brasil, 2001) para coliformes a $45^{\circ} \mathrm{C}$.

7 Embora as contagens de Staphylococcus coagulase positiva tenham sido baixas (0 a $1,1 \times 10^{2} \mathrm{UFC} / \mathrm{mL}$ ) e bem abaixo da dose infectiva, $44,4 \%$ das amostras de leite tipo A, 11,1\% das amostras de leite tipo B e 55,6\% das amostras de leite tipo C, apresentaram-se contaminadas por essas bactérias, as quais deveriam ter sido destruídas na pasteurização industrial..

8 Nenhuma amostra de leite analisada apresentou Salmonella em $25 \mathrm{~mL}$, o que as coloca em acordo com os padrões microbiológicos legais vigentes (ANVISA, 2001 e DIPOA, 2002).

9 A pasteurização no Laboratório de Microbiologia de Alimentos do Departamento de Agroindústria, Alimentos e Nutrição da ESALQ-USP mostrou-se eficiente, principalmente na redução, em ciclos logarítmicos, dos microrganismos mesófilos e psicrotróficos, para todas as amostras de diferentes tipos de leite analisadas. Após a pasteurização no laboratório, todas as amostras se enquadraram nos padrões microbiológicos legais vigentes no país, bem como não apresentaram bactérias potencialmente patogênicas como as do grupo Staphylococcus coagulase positiva. 


\section{REFERÊNCIAS BIBLIOGRÁFICAS}

AGNESE, A.P. Avaliação físico-química do leite cru comercializado informalmente no município de Soropédica-RJ. Higiene Alimentar, v.16, n.91, p.58-61, maio/jun. 2002.

AJZENTAL, A. Caminhos do leite: da ordenha ao consumidor. Leite e Derivados, v.3,n.18, p. 29-40, 1994.

AJZENTAL, A.; RICCETTI, R.V.; KRUTMAN, F.K. Influência da taxa de contaminação inicial do leite sobre o resultado da pasteurização. Leite e Derivados, v.5,n.29, p.41-54, 1996.

ANDRADE, N.J.; AJAO, D.B.; ZOTTOLA, E.A. Growth and adherence on stailess steel by Enterococcus faecium cells. Journal of Food Protection, v.61, n.11, p.1454-1458, 1998.

ASSOCIAÇÃO BRASILEIRA DE NORMAS TÉCNICAS. Bactérias coliformes totais, coliformes fecais e Escherichia coli em alimentos: determinação pelo número mais provável (NMP); MB 3463. Rio de Janeiro, 1991. 7p.

ASSOCIATION OF OFFICIAL ANALYTICAL CHEMISTRY. Official methods of analysis: official method 989. 13.ed. Arlington, 2000. 2v. 
BARANCELLI, G.V. Avaliação de métodos para a enumeração de microrganismos aeróbios mesófilos e coliformes em leite cru. Piracicaba, 2002. 68p. Dissertação (Mestrado) - Escola Superior de Agricultura "Luiz de Queiroz", Universidade de São Paulo.

BARROS, V.R.M.; JARDIM, F.S.F.; MACHADO, P.F. Quebra do paradigma da qualidade do leite $\mathrm{C}$, recebido em usina de beneficiamento sob inspeção federal, em Catanduva-SP. Higiene Alimentar, v.13, n.65, p.6-9, out. 1999.

BONASSI, A.T. Métodos atuais e modernos para análise do leite e derivados. Revista do Instituto de Laticínios Cândido Tostes, v.39 n.235,p.17-22, 1984.

BRAMLEY, A.J.; McKINNON, C.H. The microbiology of raw milk. In: ROTHWELL, R. K. (Ed.). Dairy microbiology. London: Elsevier, 1990. v.1, cap.5, p.163-207.

BRANDÃO, S.C.C.; REIS, J.S. Extinção dos leites tipo B e C: Utopia ou necessidade imperiosa? Boletim Sociedade Brasileira Ciência e Tecnologia de Alimentos, v.29, n.2, p.125-128, jul.dez. 1995.

BRASIL. Ministério da Agricultura, Pecuária e Abastecimento. Regulamento da Inspeção Industrial e Sanitária de Produtos de Origem Animal-RIISPOA: (aprovado Decreto n.30.691, de 29/03/52; alterado pelo Decreto n. 1.255 de 25/06/62). Brasília, 1980. 40p.

BRASIL. Ministério da Agricultura e Reforma Agrária. Métodos de análises microbiológicas para alimentos. Brasília, 1992. 73p.

BRASIL. Ministério da Agricultura, Pecuária e Abastecimento, Departamento de Inspeção de Produtos de Origem Animal - DIPOA. Instrução Normativa n.51 de 18/09/2002. http://www.baldebranco.com.br/estatistica.htm (18 maio 2004). 
BRASIL. Ministério de Agricultura, Pecuária e Abastecimento. Agencia nacional de Vigilância Sanitária - ANVISA. Resolução RDC no 12, de 2 de janeiro de 2001. http//: www//anvisa.gov.br/legis/resol/12_01hde.htm (02 maio 2004).

CATÃO, R.M.R.; CEBALlOS, B.S.O. de. Listeria spp. coliformes totais e fecais e E. coli no leite cru e pasteurizado de uma indústria de laticínios, no Estado da Paraíba (Brasil). Ciência e Tecnologia de Alimentos, v.21, n.3,. p.281-287, set./dez. 2001.

CHUNG, C.I.; BAE, I.H.; LEE, J.Y. Bacteriological quality of raw milks collected and stored under different conditions. Korean Journal of Dairy Science, v.6, n.1, p.53, 1984.

COLLINS, E.B. Heat resistant psychrotrophic microorganisms. Journal of Dairy Science, v.64, n.1, p.157-160, Jan. 1981.

D’AOUST, J. Y. Salmonella. In: DOYLE, M.P. (Ed.). Foodborne bacterial pathogens. New York: Marcel Dekker, 1989. cap 6, p.327-445.

DOYLE, M. P.; CLIVER, D. O. Salmonella. In: CLIVER, D.O. (Ed.). Foodborne diseases. San Diego: Academic Press, 1990. cap. 11, p.185-204.

FNP CONSUlTORIA \& COMÉRCIO. Anualpec 2004. São Paulo, 2004. p.196-232: Perspectivas brasileiras no comércio mundial de lácteos.

FONSECA, L. F. L. Leite a granel: Modelo moderno de estocagem e transporte. Leite e Derivados, v.7,n.40, p.16-21, 1998.

FOOD AND DRUG ADMINISTRATION. Bacteriological analytical manual. 8.ed. Arlington: AOAC, 1998, p.29-34.

FRANCO, B.D.G.M. Inovação nos métodos de análise microbiológica de leite e derivados. Indústria de Laticínios, v.3, n.18. p.70-71, 1998. 
FRANCO, B.D.G.M.; LANDGRAF, M. Microbiologia de alimentos. São Paulo: Atheneu, 1996. 182p.

FRAZIER, W.C.; WESTHOFF, D.C. Microbiologia de los alimentos. 4.ed. Zaragoza: Acribia, 1993. 677p.

FREITAS, J.A.; OLIVEIRA, J.P. de; SUMBO, F.D. Características físico-químicas e microbiológicas do leite fluido exposto ao consumo na cidade de Belém, Pará. Higiene Alimentar, v.16, n.10, p.89-96, 2002.

FURTADO, M.M. Pasteurização do leite por ejetor de vapor: Considerações sobre a diluição do leite e rendimento da fabricação do queijo prato. Revista do Instituto de Laticínios Cândido Tostes, v.43,n.256, p.3-9, 1988.

GARCIA, C.A.; SILVA, N.R.; LUQUETTI, B.C.; MARTINS, I.P.;SILVA, R.T.; VIEIRA, R.C. Influência do ozônio sobre a microbiota do leite "in natura". Higiene Alimentar, v.11, n.70, p.36-50, 2000.

GIOMBELLI, A. Método tradicional clássico para detecção de Salmonella em alimentos: Um problema técnico bastante complexo. Higiene Alimentar, v.14, n.68/69, p.58-62, 2000.

GIOMBELli, A.; SILVA, N.L. Avaliação do método tradicional para detecção de Salmonella spp. em carnes in natura. Higiene Alimentar, v.15, n.87, p.63-67, 2001.

GONÇALVES, R.M.S.; FRANCO, R.M. Determinação da carga microbiana em leite pasteurizado tipo "B" e "C", comercializados na cidade do Rio de Janeiro, RJ. Higiene Alimentar, v.12, n.53, p.61-65, jan/fev, 1998.

GOUNOT, A.M. Psychrophilic and psychrotrophic microorganisms. Nederlands Melk en Zuiveltijds, n.42, p.1192-1197, 1986. 
HAJDENWURCEL, J.R. Atlas de microbiologia de alimentos. São Paulo: Fonte Comunicações e Editora, 1998. 66p.

HAJDENWURCEL, J.R.; BRANDÃO, S.C.C.; LERAYER, A.L.S. Nova legislação comentada de produtos lácteos. São Paulo: Fonte Comunicações e Editora, 2002. $327 \mathrm{p}$.

HARVEY, W.C.; HILL, H. Leche: production y control. Madrid: Academia, 1989. $595 p$.

HAYES, P.R. Food microbiology and hygiene. 2.ed. New York: Chapman and Hall, 1995. 516p.

HOFFMAN, F.L.; GARCIA-CRUZ, C.H.; VENTURIM, T.M. Microbiologia do leite pasteurizado tipo "C" comercializado na região de São José do Rio Preto-SP. Higiene Alimentar, v.13, n.65, p.51-54, out. 1999.

JAY, J.M. Modern food microbiology. 5.ed. New York: Chapman and Hall, 1996. $661 \mathrm{p}$.

JAY, J.M. Modern food microbiology. 6.ed. Gaithersburg: Aspen Publishers, 1998. $661 \mathrm{p}$

LEITE, C.C.; GUIMARÃES, A.G.; ASSIS, P.N.; SILVA, M.D.; ANDRADE, C.S. Qualidade bacteriológica do leite integral (tipo C) comercializado em Salvador Bahia. Revista Brasileira de Saúde, v.3, n.1, p21-25 , 2002.

LEITE JUNIOR, A.F.S.; TORRANO, A.D.M. Variação sazonal das contagens microbiológicas do leite tipo "C" pasteurizado e comercializado em João Pessoa-PB. Higiene Alimentar,v.11, n.48. p.41-44, mar./abr.1997. 
LEITE JUNIOR, A.F.S.; TORRANO, A.D.M.Qualidade microbiológica do leite tipo "C" pasteurizado, comercializado em João Pessoa-PB. Higiene Alimentar,v.14, n.74, p.45-49, Jul. 2000.

LE MINOR, L. Facultatively anaerobic Gram-negative rods: Genus III. Salmonella. In: KRIEG, N.R. ; HOLT, J.G. (Ed.). Bergey’s manual of systematic bacteriology. 9.ed. Baltimore: Willians \& Wilkins, 1984. v.1, p.408-600.

LIMA, M.C. Efeito de tratamentos térmicos do leite tipo $\mathrm{C}$ em grupos de microrganismos e em seu desenvolvimento e estocagem em diferentes temperaturas. Viçosa, 1998. 90p. Dissertação (M.S.) - Universidade Federal de Viçosa.

LOPEZ, A.C.S.; STAMFORD, T.L.M. Pontos críticos de controle no fluxograma de beneficiamento do leite pasteurizado. Archivos Latinoamericanos de Nutrición, v.47, n.4, p.367-371, 1997.

MATNER, R.R.; FOX, T.L.; McIVER, D.E.; CURIALE, M.S. Efficacy of the Petrifilm ${ }^{\mathrm{TM}}$ E. coli count plates for $E$. coli and coliform enumeration. Journal of Food Protection, v.53, n.2, p.145-150, 1990.

McALLISTER, J.S; RAMOS, M.S.; FOX, T.L. Evaluation of the 3M dry medium culture plate (Petrifilm ${ }^{\mathrm{TM}} \mathrm{SM}$ ) method for enumerating bacteria in processed fluid milk samples. Journal of Food Protection, v.7, n.12, p.632-635, 1987.

MORENO, I.; VIALTA, A.; LERAYER, A.L.S.; SALVA, T.J.G.; VAN DEN DER, A.G.F.; MACHADO, R.C. Qualidade microbiológica de leites pasteurizados produzidos no Estado de São Paulo. Indústria de Laticínios, n.13, p.56-61, 1999.

MUIR, D.D. The shelf-life of dairy products: 1. Factors influencing raw milk and fresh products. Journal of the Society of Dairy Technology, v.49, n.1, p.24-32, 1996. 
MUTUKUMIRA, A.N.; FERESU, S.B.; NARVHUS, J.A. Chemical and microbiological quality of raw milk produced by smallholder farmers in Zimbabwe. Journal of Food Protection, v.59, n.9, p.984-987, 1996.

NADER-FILHO, A. Características microbiológicas do leite pasteurizado dos tipos "B" e "C" processados por algumas usinas de beneficiamento do Estado de São Paulo. Higiene Alimentar, v.10, n.43, p.30-32, 1996.

NADER-FILHO, A.; AMARAL, L.A.; ROSSI JR., O.D. Características microbiológicas do leite pasteurizado tipo "Integral", processado por algumas mini e macro-usinas de beneficiamento do Estado de São Paulo. Higiene Alimentar, v.11, n.50. p.21-23, jul.ago.1997.

NASCIMENTO, G.G.F.; FIGUEIREDO, S.H.M.; IBISSES, O.B.; ANTONELLI, E.M. Condições microbiológicas do leite pasteurizado comercializado em Piracicaba, SP. Boletim da Sociedade Brasileira de Ciência e Tecnologia de Alimentos, v.25,n.1,p.13-21, jan.jun. 1991.

OLIVEIRA, A.J.; CARUSO, J.G.B. Leite: obtenção e qualidade do produto fluido e derivados. 2.ed. Piracicaba: FEALQ, 1996 cap.3, p.27-43: Controle de qualidade do leite.

OLIVEIRA, S.J. Salmonella. In: GUERREIRO, M.G.; OLIVEIRA, S.J.; SARAIVA, D.; WIEST, J.M.; LEIBERNECHT, F.; POESTER, F.P.; ATHAIEDE DIAS, J.C.; FERNANDES, J.C.T.; LANGELOH, A.; BAPTISTA, J.H.P. Bacteriologia especial com interesse em saúde animal e saúde pública. Porto Alegre: Sulina, 1984. cap. 14, p.162-77.

PADILHA, M.R.F.; FERNANDES, Z.F. Avaliação da qualidade higiênico-sanitária do leite tipo"C" comercializado em Recife-PE. Higiene Alimentar, v.13, n.61, p.105109, abr/maio 1999. 
PEELER, J.T.; HOUGHTBY, G.A.; RAINOSEK, A.P. The most problabe number technique. In: VANDERZANT, C.; SPLITTSTOESSER, D.F. (Ed.). Compendium of methods for the microbiological examination of foods. 3.ed. Washington: APHA, 1992. cap.6, 105-120.

PELCZAR, M.; REID, R.; CHAN, E.C.S. Microbiologia. São Paulo: McGraw-Hill do Brasil, 1996. 2v.

PEREIRA, M.L.; PEREIRA, J.L.; SERRANO, A.M.; BERGDOLL, M.S. Estafilococos: Até onde sua importância em alimentos? Higiene Alimentar, v.14, n.68, p.32-40, 2000.

POLEGATO, E.P.S. Estudo das características físico-químicas e microbiológicas dos leites produzidos por mini-usinas da região de Marília-SP/Brasil. Higiene Alimentar, v.13, n.61, p.64-65, abr.maio 1999.

PONSANO, E.H.G.; PINTO, M.F.; JORGE, A.F.L. Variação sazonal e correlação entre propriedades do leite utilizadas na avaliação de qualidade. Higiene Alimentar, v.13, n.64, p.35-38, 1999.

ROGICK, F.A. Produção higiênica do leite. Revista do Instituto de Laticínios Cândido Tostes, v.37, n.221, p.35-38, 1987.

ROITMAM, I.; TRAVASSOS, R.; AZEVEDO, J.L. Tratado de microbiologia. São Paulo: Manole, 1988. v.1, 186p.

SANTANA, E.H.W. Microrganismos psicrotróficos em leite. Higiene Alimentar, v.15, n.88. p.27-33, set. 2001. 
SANTOS, C.C.M.; PERESI, J.T.M.; LOPES, M.R.V. Avaliação microbiológica e físicoquímica do leite pasteurizado comercializado na região de São José do Rio Preto-SP. Revista do Instituto Adolfo Lutz, v.1, n.58, p.85-89, 1999.

SANTOS, D.; BERGMANN, G.P. Influência da temperatura durante o transporte, na qualidade microbiológica do leite cru. Parte I - Mesófilos Aeróbios. Higiene Alimentar, v.17, n.109, p.69-74, jun. 2003.

SANTOS, E.S. Psicrotróficos: conseqüências de sua presença em leites e queijos. Boletim da Sociedade Brasileira de Ciencia e Tecnologia de Alimentos, v.33, n.2, p.129-138, 1999.

SBAMPATO, C.G. Influência de dois sistemas de pasteurização na composição do leite e do soro do queijo tipo gorgonzola. Revista do Instituto de Laticínios Cândido Tostes, v.53, n.305, p.15-22, 1998.

SHAH, N.P. Psychrotrophs in milk: a review. Milchwissenschaft, v.49, n.48, p.432437, 1994.

SILVA, N.; JUNQUEIRA, V.C.A.; SILVEIRA, N.F.A. Manual de métodos de análise microbiológica de alimentos. São Paulo: Varela, 1997. 295p.

SILVA, N.; NETO, R.C.; JUNQUEIRA, V.C.A.; SILVEIRA, N.F.A. Manual de métodos de análise microbiológica da água. Campinas: ITAL, Núcleo de Microbiologia, 2000. 99p.

SILVEIRA, I.A. Influência de microrganismos psicrotróficos sobre a qualidade do leite refrigerado. Uma revisão. Higiene Alimentar, v.12, n.55, p.21-26, maio 1998.

SIQUEIRA, R.S. Manual de microbiologia de alimentos. Brasília: EMBRAPA, SPI; Rio de Janeiro: EMBRAPA, CTAA, 1995. 159p. 
SORHAUNG, T.; STEPANIAK, L. Psychrotrophs and their enzymes in milk and dairy products: Quality aspects. Food Science \& Technology, v.8, p.35-41, Feb. 1997.

SOUZA, M.R.; CERQUEIRA, M.M. Pasteurização lenta e rápida: Uma avaliação de eficiência. Leite e Derivados, v.5, n.29, p.55-64, 1996.

STATISTICAL ANALYSIS SYSTEM INSTITUTE. Sas/Qc software: usage and reference. 2.ed. Cary, 1996. 2v.

TAVARES, S.G. Avaliação das condições microbiológicas do leite pasteurizado tipos A, B e C, comercializados na cidade de Piracicaba, SP. Piracicaba, 1996. 84p. Dissertação (Mestrado) - Escola Superior de Agricultura "Luiz de Queiroz", Universidade de São Paulo.

TEIXEIRA, A.M.; MASSAGUER, P.R.; FERREIRA, E.C.; TOSELlO, R.M. Agilizando a contagem de bactérias em leite cru brasileiro. Indústria de Laticínios, v.4, n.25, p.46-49, 2000.

TOWNSEND, D.E.; NAQUI, A. Comparison of SimPlate total plate count test with agar method for detection and quantitation of bacteria in food. Journal of Association of Official Analytical Chemists, v.81, n.3, p.563-569, 1998.

TOWNSEND, D.E.; IRWING, R.L.; NAQUI, A. Comparison of SimPlate coliform and Escherichia coli Test with Petrifilm, three-tube NMP, and VRBA+MUG methods for enumerating coliforms and E. coli in food. Journal of Food Protection, v.61, n.4, p.444-449, 1998.

TRABUlSI, L.R.; ALTERTHUM, F.; GOMPERTZ, O.F.; CANDEIAS, J.A.N. Microbiologia. 3. ed. São Paulo: Atheneu, 1999. 166p. 
VANDERZANT, C.; SPLITTSTOESSER, D.F. Compendium of methods for the microbiological examination of foods. 3.ed. Washington: American Public Health Association, 1992. 1219p.

VIEIRA, D.A. Os microrganismos como indicadores de qualidade. Revista do Instituto de Laticínios Cândido Tostes, v.31, n.185, p.11-19, 1976.

VIEIRA, M.B.C. M.; DIAS, S.R.; SOUZA, J.M.; SILVA, S.O. Avaliação da qualidade microbiológica de leite, cru, pasteurizado tipo $\mathrm{C}$ e pasteurizado integral/Fazenda, comercializados em algumas cidades mineiras, 1994. In: CONGRESSO NACIONAL DE LATICÍNIOS, 13., Juiz de Fora, 1995. Resumos. Juiz de Fora: FAPEMIG, 1995. p.139-141.

VILLAR, A.; GARCIA, J.A.; IGLESIAS, L. Application of principal component analysis to the study of microbial populations in refrigerated raw milk from farms. International Dairy Journal, v.6, n.10, p.937-945, 1996.

ZOLI, J.A.; NEGRETE, I.R.A.; OLIVEIRA, T.C.R.M. Avaliação da contaminação por Staphylococcus aureus e Salmonella spp., em maionese de batata comercializada em Londrina, PR. Higiene Alimentar, v.16, n.95, p.62-71, 2002.

WENDPAP, L.L.; ROSA, O.O. Qualidade microbiológica do leite pasteurizado tipo C comercializado em Cuiabá - MT. Higiene Alimentar, v.9, n.39. p.11-14, set./out.1995.

WENDPAP, L.L.; ROSA, O.O. Avaliação microbiológica do leite pasteurizado tipo C comercializado em Cuiabá - MT. Higiene Alimentar, v.17, n.47. p.17-20, jan./fev. 1997. 